\title{
Employment and industrial relations in the Dutch call center sector
}

Citation for published version (APA):

Sieben, I. J. P., de Grip, A., \& van Jaarsveld, D. (2005). Employment and industrial relations in the Dutch call center sector. Researchcentrum voor Onderwijs en Arbeidsmarkt, Faculteit der Economische Wetenschappen. ROA Reports No. 4E https://doi.org/10.26481/umarep.200504E

Document status and date:

Published: 01/01/2005

DOI:

10.26481/umarep.200504E

Document Version:

Publisher's PDF, also known as Version of record

\section{Please check the document version of this publication:}

- A submitted manuscript is the version of the article upon submission and before peer-review. There can be important differences between the submitted version and the official published version of record.

People interested in the research are advised to contact the author for the final version of the publication, or visit the DOI to the publisher's website.

- The final author version and the galley proof are versions of the publication after peer review.

- The final published version features the final layout of the paper including the volume, issue and page numbers.

Link to publication

\footnotetext{
General rights rights.

- You may freely distribute the URL identifying the publication in the public portal. please follow below link for the End User Agreement:

www.umlib.nl/taverne-license

Take down policy

If you believe that this document breaches copyright please contact us at:

repository@maastrichtuniversity.nl

providing details and we will investigate your claim.
}

Copyright and moral rights for the publications made accessible in the public portal are retained by the authors and/or other copyright owners and it is a condition of accessing publications that users recognise and abide by the legal requirements associated with these

- Users may download and print one copy of any publication from the public portal for the purpose of private study or research.

- You may not further distribute the material or use it for any profit-making activity or commercial gain

If the publication is distributed under the terms of Article $25 \mathrm{fa}$ of the Dutch Copyright Act, indicated by the "Taverne" license above, 


\section{Employment and Industrial Relations in the Dutch Call Center Sector}

ROA-R-2005/4E

Andries de Grip

Inge Sieben

Danielle van Jaarsveld

Research Centre for Education and the Labour Market

Faculty of Economics and Business Administration Maastricht University

Maastricht, April 2005 
ISBN 90-5321-407-0

Sec05.023.doc 


\section{Contents}

Acknowledgements

1 Introduction 1

2 Call Center Industry Overview 5

2.1 Call Center Categories 5

2.2 Services and Calls 6

2.3 Characteristics of Call Centers 9

$\begin{array}{ll}2.4 \text { Human Resource Management } & 13\end{array}$

3 Technology, Work Organization, and Staff Selection 15

$\begin{array}{ll}3.1 \text { Technology } & 15\end{array}$

3.2 Organization of Work: Discretion, Participation, and Teamwork 17

$\begin{array}{ll}3.3 \text { Selection and Staffing Strategies } & 21\end{array}$

3.4 Role of Temporary Work Agencies 26

4 Wages, Working Conditions, and Personnel Turnover 33

4.1 Pay Levels and Total Compensation 33

$\begin{array}{ll}4.2 \text { Working Conditions } & 37\end{array}$

$\begin{array}{lll}4.3 & \text { Personnel Turnover } & 40\end{array}$

5 Training and Career Opportunities $\quad 43$

5.1 Training 43

5.2 Career Opportunities $\quad 50$

6 Industrial Relations and Collective Bargaining 53

6.1 Labor Relations $\quad 53$

6.2 Collective Bargaining 56

6.3 Some Comparisons with Germany 60 



\section{Acknowledgements}

The authors gratefully acknowledge generous financial support from the Dutch Ministry of Social Affairs (grant AV 41-22), and the U.S. Russell Sage Foundation (grant 44924-7417). We would like to thank Harold de Bock and Gerrit Piksen of MarketResponse Nederland for giving us the opportunity to join in the NCCBP 2004 survey, and for their assistance with the additional questionnaire. Esther Soudant helped with the data entry for the additional survey. We are also greatly indebted to many key players for answering our questions during the qualitative part of the research: representatives of social partners, call center managers, HR managers, IT managers, supervisors, and managers of temporary work agencies. We would like to thank Peter Bain for providing us with some initial contacts in the field. Finally, we appreciate helpful input from the research team of the wider international study (the "Global Call Centers Project"), which was initiated by Rose Batt from Cornell University in the U.S., and Steven Wood and David Holman of Sheffield University in the U.K.. We would in particular like to thank Rose Batt, David Holman and the German team, consisting of Ursula Holtgrewe, Karen Shire, and Virginia Doellgast for their useful suggestions. 



\section{Introduction}

This report focuses on employment and industrial relations in the Dutch call center sector. This fairly new industry has grown dramatically over the last decade, employing an estimated 2,5 percent of the country's workforce. ${ }^{1}$ An important distinction can be made between in-house call centers - those that serve a company's own customers - and 'subcontractors' or 'outsourced centers' - those serving the customers of other companies. In the Netherlands, the call center sector is dominated by in-house call centers; their share is estimated to range between 60 and 80 percent. $^{2}$ Employees working in in-house call centers are usually covered by a collective bargaining agreement (CAO) of the company itself or the sector of industry in which the company operates. Employees working for subcontractors are, however, covered by a collective agreement for subcontracted call centers. This CAO was reached only two years ago and can be seen as a landmark in the history of the industry. $^{3}$

Call center workforce is characterized by a significant proportion of workers in socalled 'atypical' labor contracts, such as temporary contracts, part-time contracts, irregular shifts, and 'on call' contracts. Therefore, call center workers are not very organized. In addition, the sector is confronting an image problem which makes it difficult to recruit new employees. Public perceptions are that call center work requires practically no skills and is monotonous in its nature. However, due to technological changes, more demanding customers, and an increase in the number of business-to-business contacts, employees' minimum education should be at MBO level.

In this respect, call centers find themselves in a vicious circle. On the one hand, a formal educational program for customer service representatives (agents) is absent from the regular education curriculum. Consequently, call center employers are forced to train their employees in communication skills, customer handling, product knowledge, and computer skills. On the other hand, call center employers worry that these training investments might be lost through turnover, since other call centers may hire trained employees away. ${ }^{4}$ This makes that more and more call centers put the question 'how can we succeed in retaining our personnel by being a good employer?' on their HRM agenda. This concern has, without a doubt, contributed to

1. NFIA (2004). Shared Service Centers. Netherlands Foreign Investment Agency.

2. Braaksma, R.M. (1998). Bedrijfsleven in beeld: Callcenters. Zoetermeer: EIM

3. As we will discuss more in detail in Chapter 6 , the first collective agreement (CAO) for subcontracting call centers ended in May, 2004, and there still is no new CAO.

4. Earlier research on employees of eight call centers in the Dutch region Arnhem/Nijmegen shows that trained customer service representatives are not more inclined to leave, see De Grip, A \& I. Sieben (2004). Training and Expectations on Job Mobility in the Call Centers Sector. Journal of European Industrial Training, 28: 257-271. 
the establishment of the first collective bargaining agreement for outsourced call centers in $2003 .{ }^{5}$

Since the call center sector is a relative new industry, it is not present in the main statistics of Statistics Netherlands. This implies that little up-to-date information about personnel and labor market developments is available for the call center sector. This might hamper the development of labor relations at a central level, since lack of objective information makes that social partners may easily differ in their interpretation of the importance of specific developments or problems in the sector. It thus is of eminent importance to study different aspects of the call center sector that could play a part in improving the quality of labor relations.

This report tries to contribute to this improvement by studying employment and industrial relations in the Dutch call center sector. The information presented in this study is based on extensive field study, site visits, interviews, and large-scale surveys. The site visits and interviews took place in two rounds, one in November 2003 and one in June 2004. The call centers we visited were a mix of in-house call centers in several industries (like financial services, telecommunications, and the public sector), and subcontractors, both general and specialized. These call centers serve different customer segments - from mass market to business clients. They were either part of a multinational or entirely Dutch. Some call centers in the Netherlands also serve international customers.

In each call center, we interviewed the general manager, an HRM manager, an IT manager, and a supervisor. In addition, we interviewed delegates of social partners in the sector: the largest employer organization for in-house call centers (VCN), the largest employer organization for subcontractors (WGCC), and the largest union in the call center sector (FNV Bondgenoten). Finally, we interviewed representatives from two large temporary work agencies which specialize in call center work.

In addition to this qualitative information, we analyzed quantitative data from the 7th National Contact Center Benchmark Survey administered by the NCCBP in April to August 2004. First, a written questionnaire was mailed to approximately 800 call center managers of all in-house call centers and subcontractors known to the NCCBP. A total of 116 managers responded with a completed questionnaire. Second, an additional questionnaire was sent to these participating managers in September 2004, with 50 responding to the additional survey. The figures and tables presented in this report are based on these two surveys. It should be noted that we only show statistics when a sufficient number of observations is reached. In some figures and tables, statistics are missing for specific categories of call centers.

Both the qualitative information and the quantitative data are analyzed in this report to provide a detailed picture of the Dutch call center industry. Moreover, since this study is part of an international call center study (the 'Global Call Center (GCC)

5. WGCC (2003). Collectieve Arbeidsovereenkomst Facilitaire Callcenters in Nederland 2003-2004. Leidschendam. 
Project' in which 20 countries are involved), international comparisons will be made, in particular with call centers in the United States and Germany. These two countries provide interesting comparisons, because they represent quite different institutional settings from the Netherlands. The U.S. is characterized by a non-regulated, liberal economy, whereas Germany, in contrast, is a regulated, coordinated society. Although the Dutch industrial relations system shares some similarities with the German one (like industry based bargaining, mandatory works councils, and sectoral unions), ${ }^{6}$ the Dutch system is driven by 'organized' decentralization and individualization. ${ }^{7}$ This so-called polder model has induced the (earlier) acceptance of more flexible employment strategies than in Germany.

\section{Outline of the Report}

The structure of this report is as follows. First, Chapter 2 begins with an overview of the call center sector in the Netherlands. Dutch call centers, for example, vary in the services they provide, the type of calls handled, the number of workers they employ, and the kind of Human Resource (HR) system they implement. Chapter 3 focuses on call centers' technology (like communication channels and tools), work organization (for example agents' discretion at work, monitoring, and teamwork), and staff selection. As call centers often have an 'atypical' workforce, we also discuss the demographic characteristics of agents and the quality of their labor contracts. Moreover, the role of temporary work agencies in the call center sector is explored in Chapter 3. Next, in Chapter 4, we analyze wages, working conditions, and personnel turnover. Particular attention is given to salaries, performance pay and fringe benefits for employees, work seat characteristics, absenteeism, and agent quit rates. Chapter 5 examines the training and career opportunities for agents. How many hours of initial and on-going training do call centers provide? What kind of training do they offer? Do agents have a personal development plan and what are their career opportunities inside and outside the call center? Finally, Chapter 6 concentrates on labor relations and collective bargaining in the Dutch call center industry. We explore the position of employer organizations, unions, and works councils and discuss the first collective agreement for subcontracting call centers.

6. Streeck, W. \& J. Visser (1998). An Evolutionary Dynamic of Trade Union Systems. MPIfG Discussion Paper 98/4. Cologne: Max Planck Institute.

7. Traxler, F. (1995). Farewell to Labour Market Associations? Organized versus Disorganized Decentralization as a Map for Industrial Relations. P. 3-19 in: Crouch, C. \& Traxler, F. (Eds). Organized Industrial Relations in Europe: What Future? Avebury: Aldershot. 



\section{Call Center Industry Overview}

\subsection{Call Center Categories}

The dramatic growth of the call center industry is a global phenomenon, fuelled by advances in information technologies and the precipitous decline in the costs of voice and data transmission over the last two decades. Datamonitor, a technology consulting firm that closely monitors the industry, has estimated that the number of Dutch call centers grew 12 percent annually in the period 1999-2002, reaching a total of 1,266 call centers in 2001 . Growth will continue in the years to come, although it will not be as high as a few years ago. The annual growth rate in the period 20022006 is predicted to be 9 percent. Thus, in 2006, the Dutch market is forecast to reach a volume of 1,992 call centers. ${ }^{8}$ The Netherlands has the second largest percentage in Europe (after Ireland) of its population employed in the call center industry: 2,5 percent. $^{9}$ This is almost comparable to the U.S., where close to 3 percent of the workforce is employed in call centers. ${ }^{10}$

Several trends have influenced the growth and profitability of call center operations. In many countries, deregulation and privatization has occurred in such industries as telecommunications, banking, and airlines. Heightened competition in these markets has created strong incentives to reduce costs through the consolidation of customer service interactions into remote call centers.

New technologies have provided the tools needed to transform the organization of customer service work. Advances in call distribution systems, skill-based routing systems, and electronic performance monitoring have made it possible to answer calls farther from their source, to automate some calls, and to segment and standardize others - leading to significant savings through economies of scale and enhanced call handling efficiency. They have also facilitated the growth of subcontractors, who specialize in providing outsourced services to companies who previously handled their operations in-house. According to the 2004 NCCBP survey, 28 percent of Dutch call centers are subcontractors. This percentage is relatively high compared to the U.S. (GCC survey: 14 percent), whereas the share of subcontractors in Germany is much higher (GCC survey: 47 percent). Still, the overwhelming majority of Dutch call centers are in-house centers - that is call centers that serve customers of the parent company (72 percent in 2004).

Throughout this report, we will analyze differences in employment and industrial relations comparing in-house call centers with subcontractors. In addition, we explore the variation within in-house call centers by analyzing differences in the kind of indus-

8. Datamonitor (2002). Call Centers Industry Profile: the Netherlands. New York: Datamonitor.

9. NFIA (2004). Shared Service Centers. London: Netherlands Foreign Investment Agency.

10. Datamonitor (1999). Opportunities in U.S. and Canadian Call Center Markets. New York: Datamonitor. 
try they serve. Figure 2.2 gives an overview of the five call center categories used in this report: in-house call centers serving retail, media, and tourism (25 percent), inhouse call centers in financial services (19 percent), in-house call centers in telecommunications, business services, and IT (15 percent), in-house call centers in public sector and utilities (13 percent) and subcontractors (28 percent). It should be noted that subcontractors often serve more than one industry. Most of them work in telecommunications, business services, and IT (34 percent) or Financial services (28 percent). Approximately 20 percent of the subcontractors serve the retail, media, and tourism industry or the public sector and utilities.

Figure 2.1

Call Center Categories in This Report

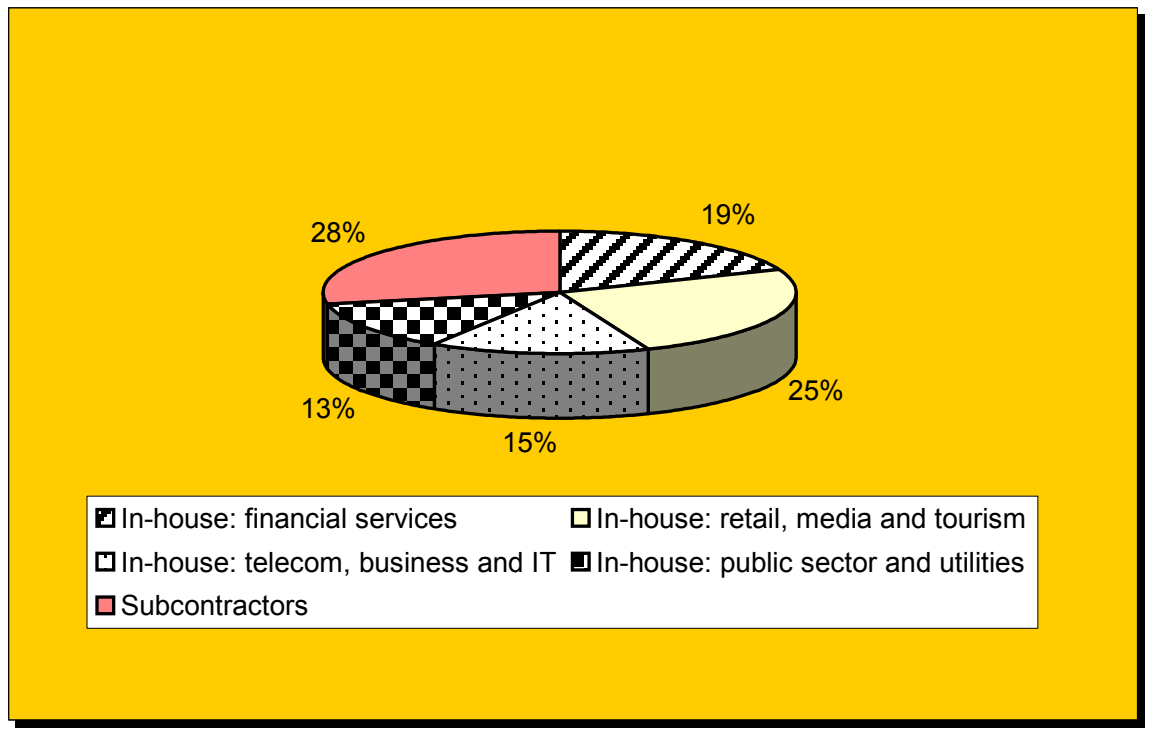

\subsection{Services and Calls}

Dutch call centers provide different types of services, ranging from service oriented functions such as handling customer complaints, providing IT helpdesk services, and supplying general customer services, to sales functions such as making reservations, telemarketing, and lead generation. Figure 2.2 shows that a vast majority of the inhouse call centers identify customer service as their main activity ( 86 percent). In particular, public sector and utilities call centers and telecommunications, business services, and IT call centers identify customer services as their main activity. Only 13 percent of the Dutch in-house call centers perform sales as their main activity. These call centers are found often in the retail, media, and tourism industry. Subcontractors, on the other hand, focus more on sales (59 percent) than on services (38 percent). Finally, 1 percent of in-house call centers and 3 percent of subcontracting call centers offer data services like database improvement and control, and market research as a primary activity. 
Figure 2.2

Types of Services Provided

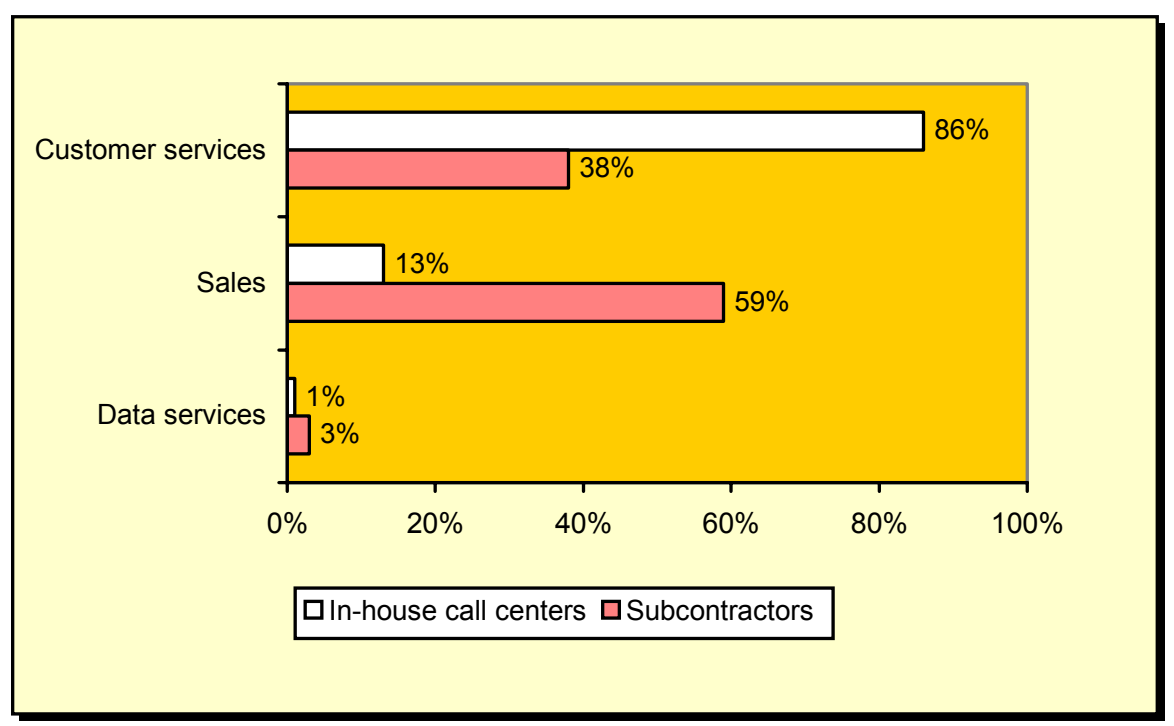

Differences in type of service are reflected in the type of calls made. Figure 2.3 shows that in-house call centers mainly deal with inbound calls, which means that customers predominantly call them (94 percent). Subcontractors on the other hand show a mix of making mainly outbound calls (36 percent), making mainly inbound calls (34 percent), and doing both inbound and outbound calls (28 percent).

Figure 2.3

Type of Calls Made

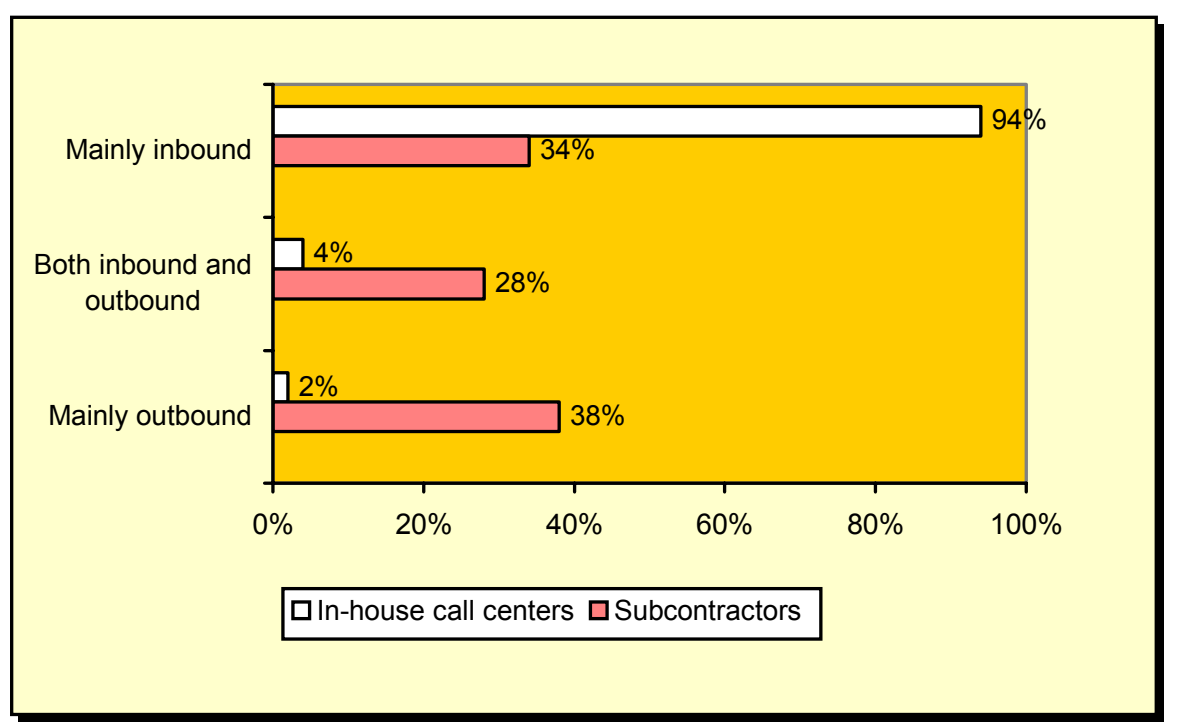


Another basis for differentiating between call centers is by customer segment served. We found that almost half of the Dutch call centers serve the mass market alone, whereas 8 percent deals with business-to-business contacts only. Historically, all companies served all customers in a given geographic area, providing 'universal' service. Nowadays, companies segment their services by particular customer groups rather than geographic location. These customer segments are typically defined by the value of their accounts, like residential customers (the mass market), small business customers, or large business customers.

Figure 2.4

International Contacts

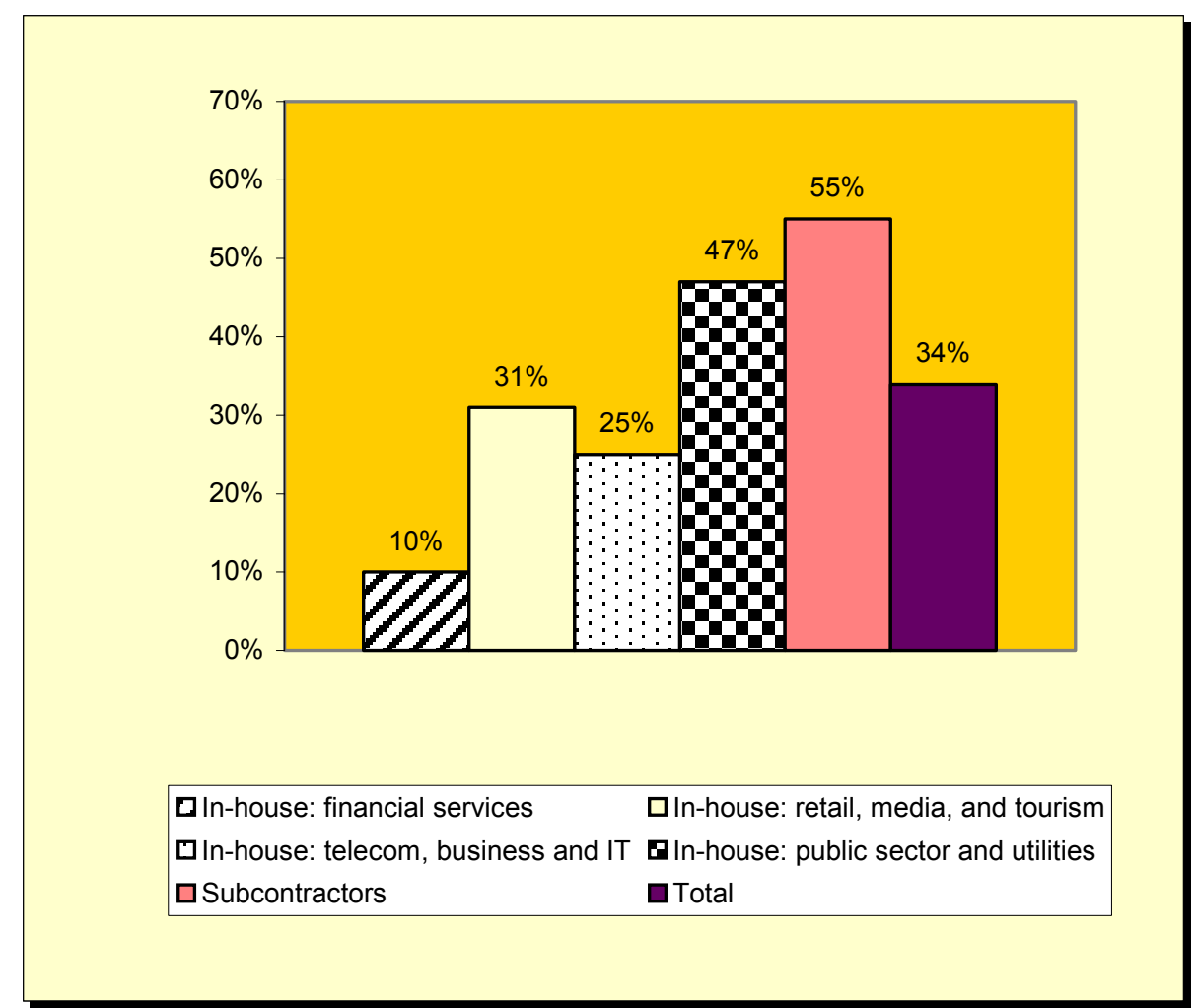

From our interviews with key players in the field, we learned that the Dutch call center industry is quite internationally oriented. The Netherlands provides an international atmosphere, with a reliable infrastructure for supporting call center businesses. Its inhabitants speak a number of foreign languages, and it is located in close proximity to neighboring countries that offer additional language capacity. These factors attract call centers with international and pan-European business. Figure 2.4 shows that about a third of all Dutch call centers handle international calls. Subcontracting call centers clearly are more internationally oriented than in-house call centers: 55 percent of the subcontractors deal with international contacts. Within the in-house call center sector, there are large differences by industry. About half of all in-house call centers in the public sector or utilities industry handle international 
calls, whereas only 10 percent of the in-house call centers in financial services have international contacts. In general, about 19 percent of Dutch call centers reported serving the international market as opposed to solely the domestic market. Datamonitor expects the Netherlands to remain a key location for multilingual and pan-European call centers. ${ }^{11}$

\subsection{Characteristics of Call Centers}

Dutch call centers also vary by size, structure, age, and market scope. While the 'typical' call center is often assumed to be a large, white-collar factory, most in fact are relatively small organizations. In this study, 60 percent of call centers have fewer than 100 employees; 28 percent have between 100 and 300 employees; and 12 percent have over 300. On average, a Dutch call center employs 172 employees (see Figure 2.5). This is slightly more than the average number of employees in German call centers (GCC survey: 115 employees). By comparison, call centers in the U.S. are usually larger in size (GCC survey: 23 percent had over 300 employees), and, on average, reported a workforce of 400 employees.

Figure 2.5

Average Size

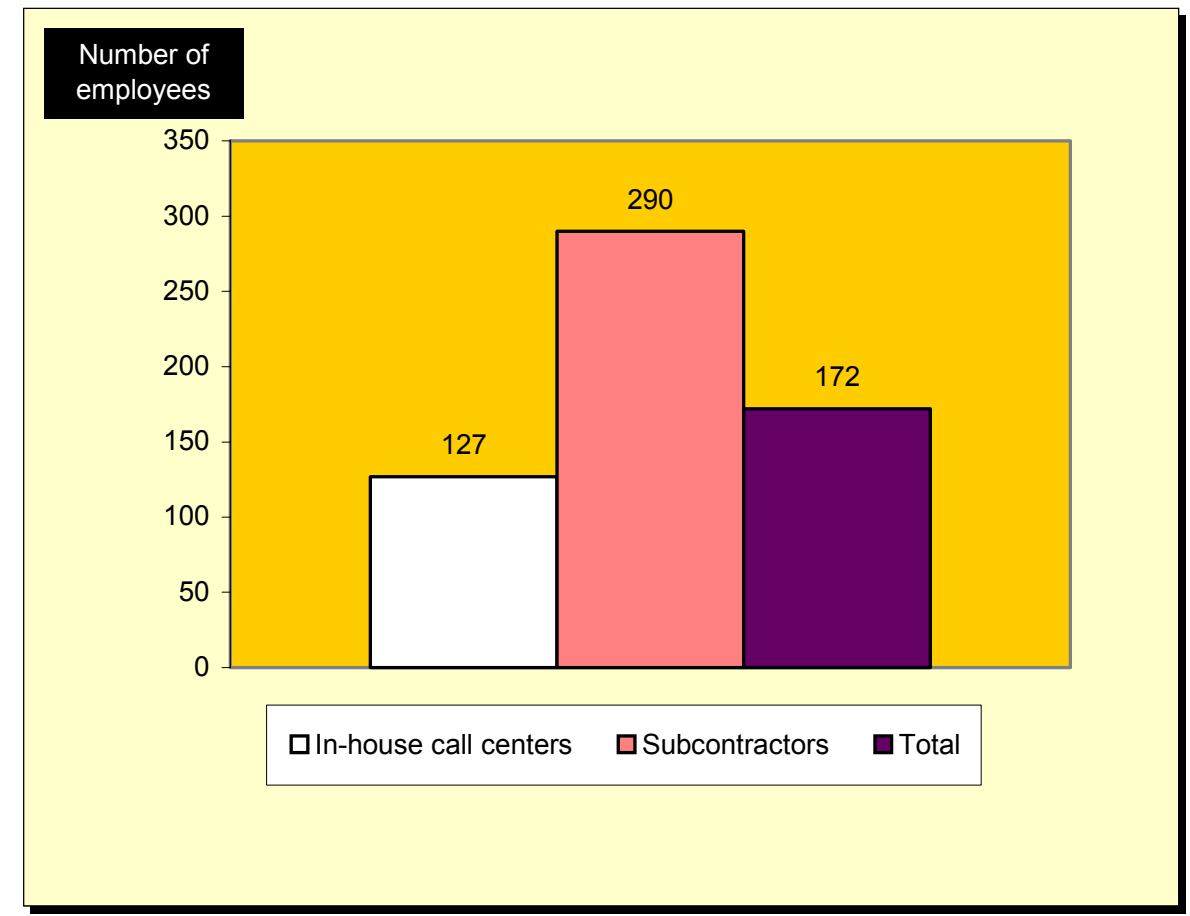

In addition, Figure 2.5 shows that the size of call centers varies substantially across the in-house or subcontracted categories. In-house call centers are smallest in size,

11. Datamonitor (2002). EMEA Call Centers to 2007. New York: Datamonitor. 
averaging 127 employees (agents, supervisors, and supporting staff) at a worksite. The largest in-house call centers are typically found in financial services (average of 188 employees). Subcontractors, by contrast, average almost 300 employees per center, which is more than twice the level of in-house call centers. The difference in size suggests that subcontracting call centers, on average, can make greater use of standardized call center technologies. These patterns will become more evident in Chapter 3 of this report, when we examine the adoption of technology and work design in call centers.

Call center agents make up 88 percent of the workforce in call centers. These customer service representatives are the call center's core employees: they handle the contact both from and to customers. In describing employment and industrial relations in this report, we predominantly focus on the working conditions for these call center agents. Across all types of call centers included in this study, team leaders and supervisors constitute approximately 8 percent of the call center's workforce and the supervisor to agent ratio is 1:14 agents (see Figure 2.6). Considering different types of call centers reveals that supervisors working in subcontracting call centers deal with fewer agents (11) than supervisors in in-house call centers (15). Finally, on average, support staff compromises about 4 percent of the call center's workforce.

Figure 2.6

Average Supervisor to Agent Ratio

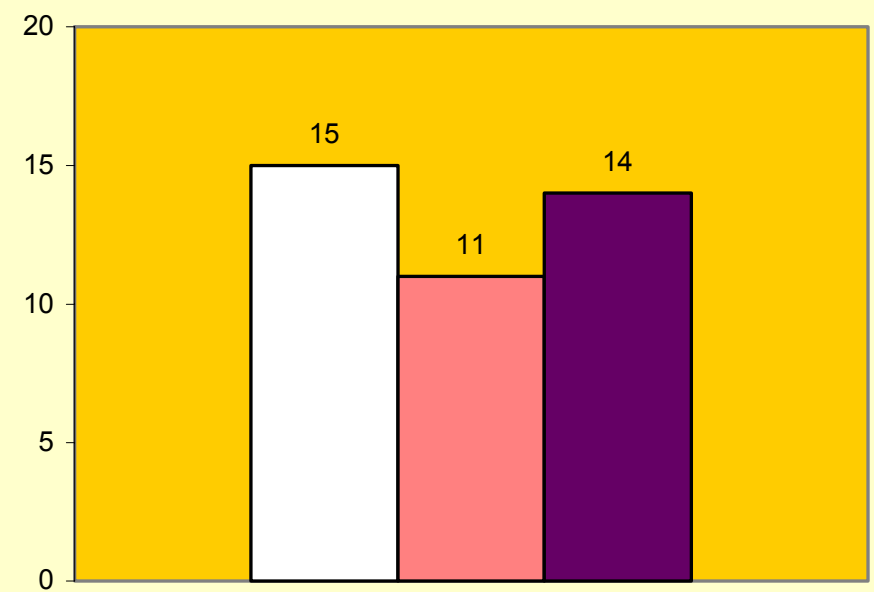

$\square$ In-house call centers $\square$ Subcontractors $\quad$ TTotal 
The age of establishment is reported in Figure 2.7. Approximately 40 percent of Dutch call centers is more than ten years in business. More than a quarter is younger than 3 years; 5 percent even is less than one year old. Call centers typically found in the in-house retail, media, and tourism industry and in telecommunications, business services, and IT industry have been in operation longer than subcontracted call centers, and those in the public sector and utilities industry. This pattern reflects the early development of catalogue sales in the retail sector and the advanced engineering systems in telecommunications.

Figure 2.7

Age of Establishment

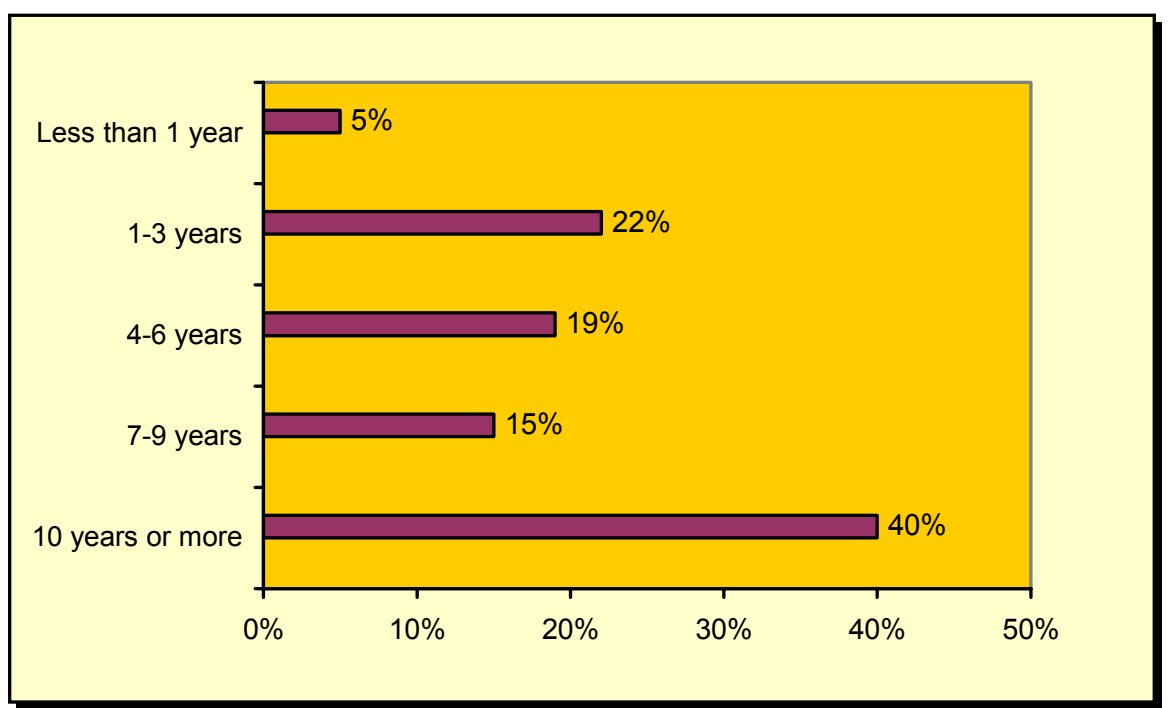

Similar to the U.S. and Germany, the majority of Dutch call centers are part of larger corporations (73 percent). These corporations, on average, have five to six call centers. Figure 2.8 shows that 63 percent of the call centers are located at one site. In-house call centers in telecommunications, business services, and IT are more likely to be found in multiple locations. Similarly, although to a lesser degree, this holds for in-house call centers in the public sector and utilities industry, with 36 percent of call centers located at multiple sites. These multiple site call centers usually perform as one business.

Our interviews reveal a growing tendency for call centers to be run as profit centers, instead of cost centers. Figure 2.9, however, indicates that most in-house call centers are still run as a cost center. Profit centers are generally found in telecommunications, business services, and IT (38 percent) and in financial services (35 percent). About half of the in-house call centers currently run as a cost center are planning a conversion into a profit center: 18 percent had already started implementing this shift at the time of the survey, whereas 32 percent were planning to do so in 2004. 
Figure 2.8

Operating One Location Site

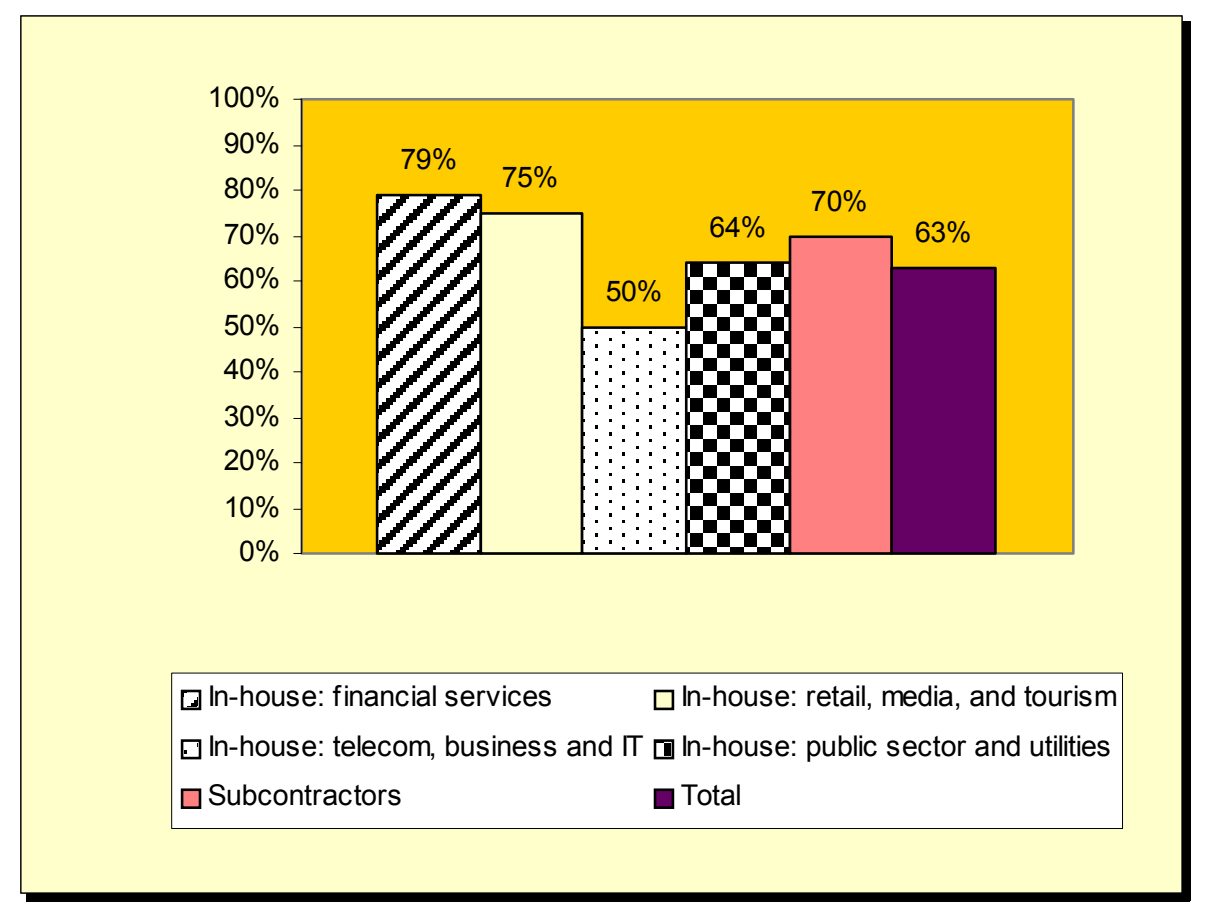

Figure 2.9

Profit Center

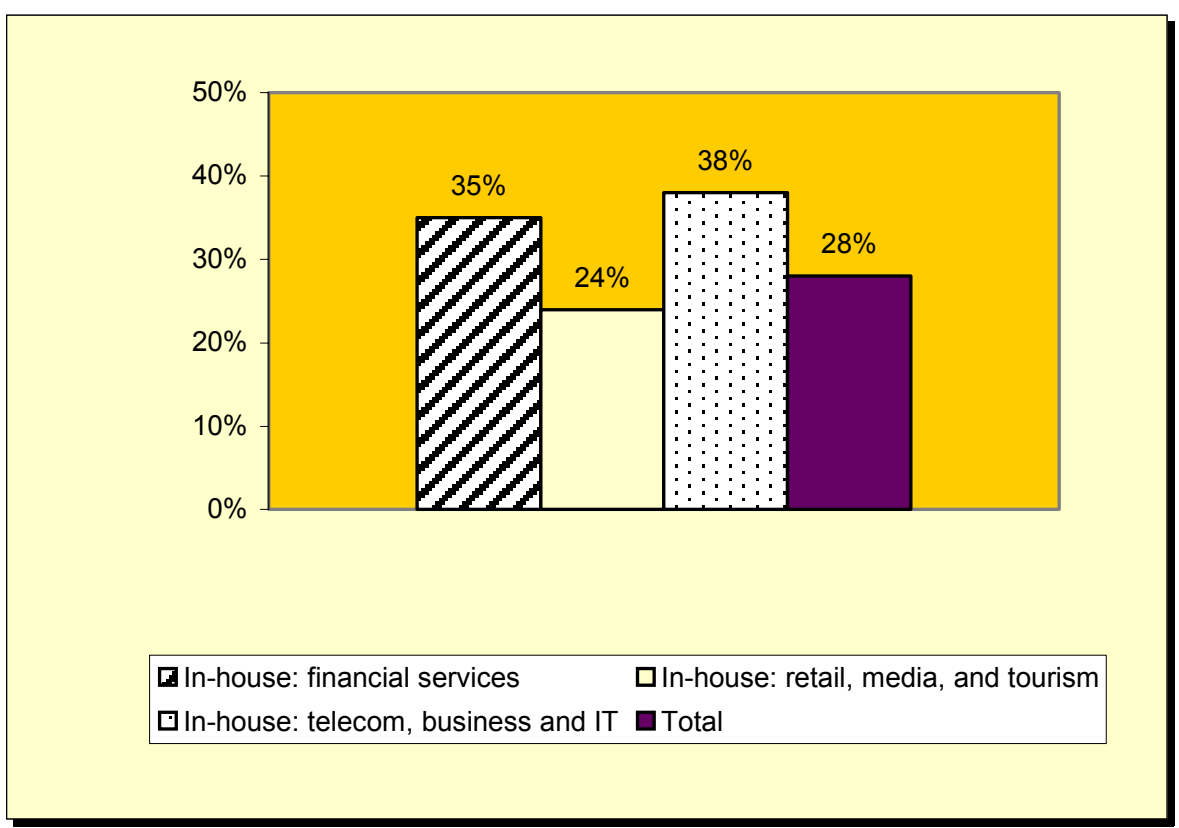




\subsection{Human Resource Management}

From the perspective of human resource (HR) management, some call centers are definitely adopting a series of coherent work and human resource practices that, in combination, create a high involvement work system that improves the quality of jobs as well as the quality of service. To estimate how much call center employers are investing in human resources, we measured their investment in the following areas:

- Skills and training: educational level of workforce (more than 90 percent of agents with at least secondary vocational education ${ }^{12}$ ) and on-going agent training (more than one week provided by the call center);

- Personnel management: personal development plans for agents (yes) and worker satisfaction surveys (yes);

- Incentives: pay level (more than 13 euros gross per hour for agents) and permanent jobs (more than 90 percent of agents with an indefinite contract).

Figure 2.10

Type of HR System

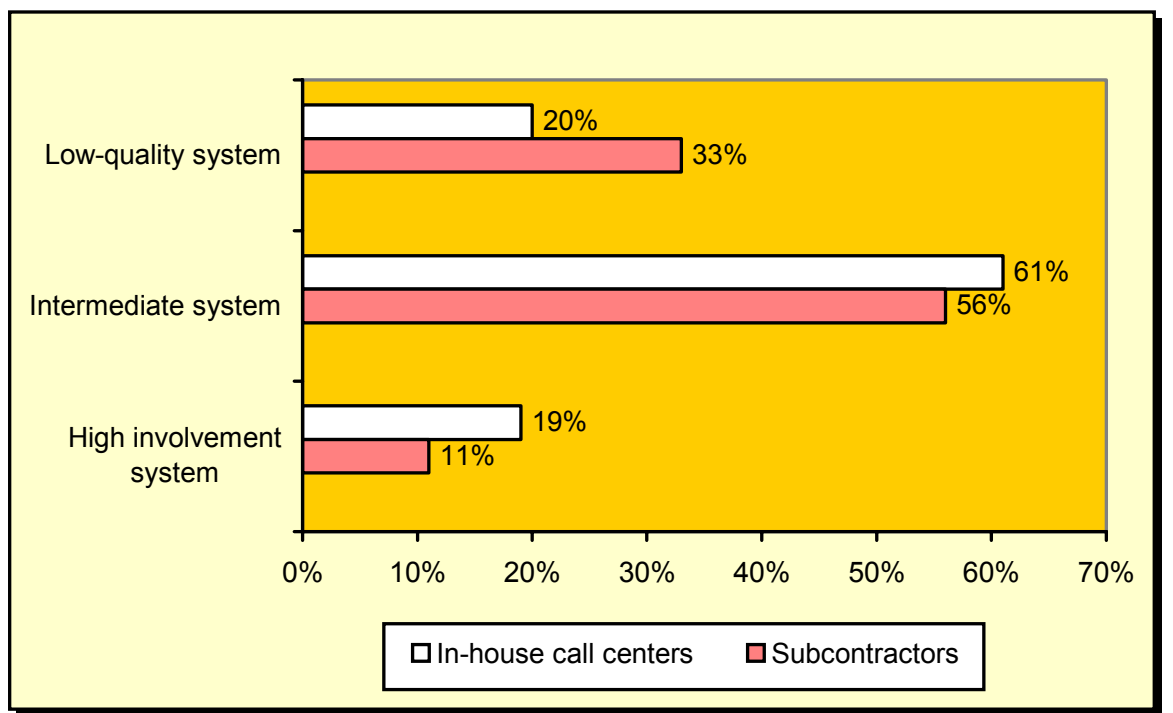

Based on these indicators, we created an index of 0 to 6 , and divided call centers into three groups: 1) low-quality system (scoring 0-1), 2) intermediate system (scoring 2-3, and 3) high involvement system (scoring 5-6). Figure 2.10 shows that a higher percentage of in-house call centers (19 percent) compared with subcontractors (11 percent) have adopted a high involvement HR system. Furthermore, we find presence of high involvement systems to be concentrated in financial services (39 percent). Call centers with a high involvement HR system generally provide services instead of sales, primarily handle inbound calls, and do

12. In the Netherlands, secondary vocational education (MBO), represents an entry level qualification for the labor market. Workers with a MBO certificate usually do skilled work. 
not handle international contacts. In the remainder of this report, we will consider whether centers with high involvement HR systems provide better working conditions and industrial relations than call centers with lower-quality HR systems. These lowquality call centers are more often found in the subcontractors sector (33 percent).

A concern that many call center employers have, because it affects their recruitment and retention, is the image of call center work. One way to address the image issue is through the professionalization of the sector, e.g. by means of certification. Several official certificates for Dutch call centers exist, which can be obtained by meeting certain conditions. Figure 2.11 shows that 9 percent of respondents has an ISO 9002 certificate, while another 12 percent plans to obtain one in 2004. This International Standards Organization certificate focuses on quality guarantees in amongst others design and development, production, and services. Roughly 3 percent of the call centers has an ITO (Institute for Telecom Organizations) certificate. This "home grown" certificate was developed two years ago by the Dutch consumers' organization (Consumentenbond), the Foundation Telecom Users Netherlands (sTN), and the Call Center Managers Association (CCMA) in order to improve contactability of call centers. Finally, nearly 1 percent have obtained a COPC (Customer Operations Performance Center) certificate, whereas 5 percent are planning to do so in 2004. The COPC certificate mainly focuses on customer service, customer satisfaction, and organizational efficiency.

Figure 2.11

Call Center Certification

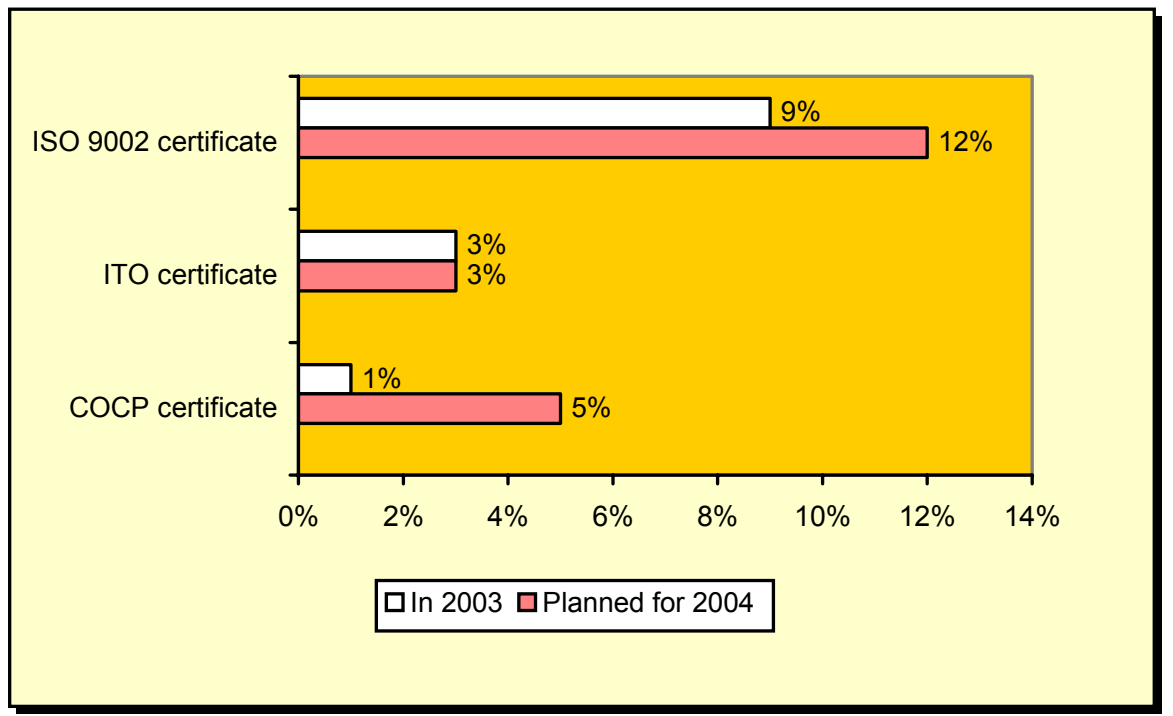




\section{Technology, Work Organization, and Staff Selection}

\subsection{Technology}

Information technology is constantly changing. Recent advances in call center technologies are creating opportunities for customer interactions to expand from voice-only channels (telephones) to multiple channels - email, fax, internet, and voice over internet protocols. These technologies enhance customer service by providing a variety of options for service and sales. Table 3.1 illustrates that most call centers use several channels to communicate with their customers. Virtually every center uses telephone contact. Surprisingly, contact by postal mail and fax is still quite popular, particularly in the in-house retail, media, and tourism industry (93 percent). Modern modes of communication such as email or web mail also is widespread: 85 percent of call centers use email or web mail. Internet or co-browsing is in use by 30 percent of call centers, whereas 8 percent uses text messaging. Overall, in-house call centers in telecommunication, business services, and IT more often use modern communication channels such as email, internet and text messaging. In addition, call centers that implemented advanced HR systems (i.e. high involvement systems) are more advanced in the use of their customer communication channels as well. They are more likely to use internet and cobrowsing, whereas call centers with low-quality systems mainly deal with customer contacts by telephone or by postal mail or fax.

Table 3.1

Use of Communication Channels

\begin{tabular}{lrrrrrr}
\hline & $\begin{array}{r}\text { In-house } \\
\text { financial } \\
\text { services }\end{array}$ & $\begin{array}{r}\text { In-house } \\
\text { retail, } \\
\text { media and } \\
\text { tourism } \\
\%\end{array}$ & $\begin{array}{r}\text { In-house } \\
\text { telecom, } \\
\text { business, } \\
\text { and IT } \\
\%\end{array}$ & $\begin{array}{r}\text { In-house } \\
\text { public } \\
\text { sector and } \\
\text { utilities } \\
\%\end{array}$ & $\begin{array}{r}\text { Sub } \\
\text { contrac- } \\
\text { tors }\end{array}$ & Total \\
& $\%$ & 100 & 100 & 100 & 100 & 100 \\
\hline & 96 & 93 & 71 & 67 & 70 & 71 \\
Telephone & 46 & 97 & 94 & 87 & 73 & 85 \\
$\begin{array}{l}\text { Postal mail or fax } \\
\text { Email or web mail }\end{array}$ & 77 & 36 & 40 & 33 & 20 & 30 \\
$\begin{array}{l}\text { Internet or } \\
\text { co-browsing }\end{array}$ & 27 & 7 & 13 & 7 & 10 & 8 \\
Text messaging & 5 & & & & &
\end{tabular}

The Dutch call center market is mature and technologically advanced. ${ }^{13}$ Figure 3.1 shows that almost 80 percent of call centers uses Interactive Voice Response (IVR) or Voice Response Units (VRU). These systems do not require any human interaction: customers use their touch-tone telephone or voice to interact with a database to acquire information from or enter data into the database. On average, 12

13. DTI (2004). The UK Contact Center Industry: A Study. London: DTI 
percent of all calls is handled with a IVR or VRU system. Speech recognition is not widespread in Dutch call centers (8 percent). Similar to U.S. call centers, only a minority of call centers have invested in Voice over IP (VOIP) technology. VOIP is a category of hardware and software that enables people to use the internet as the transmission medium for telephone calls by sending voice data in packets using Internet Protocols. In the Netherlands, 14 percent of in-house call centers and 27 percent of subcontractors use Voice over IP.

Figure 3.1

Call Center Technologies

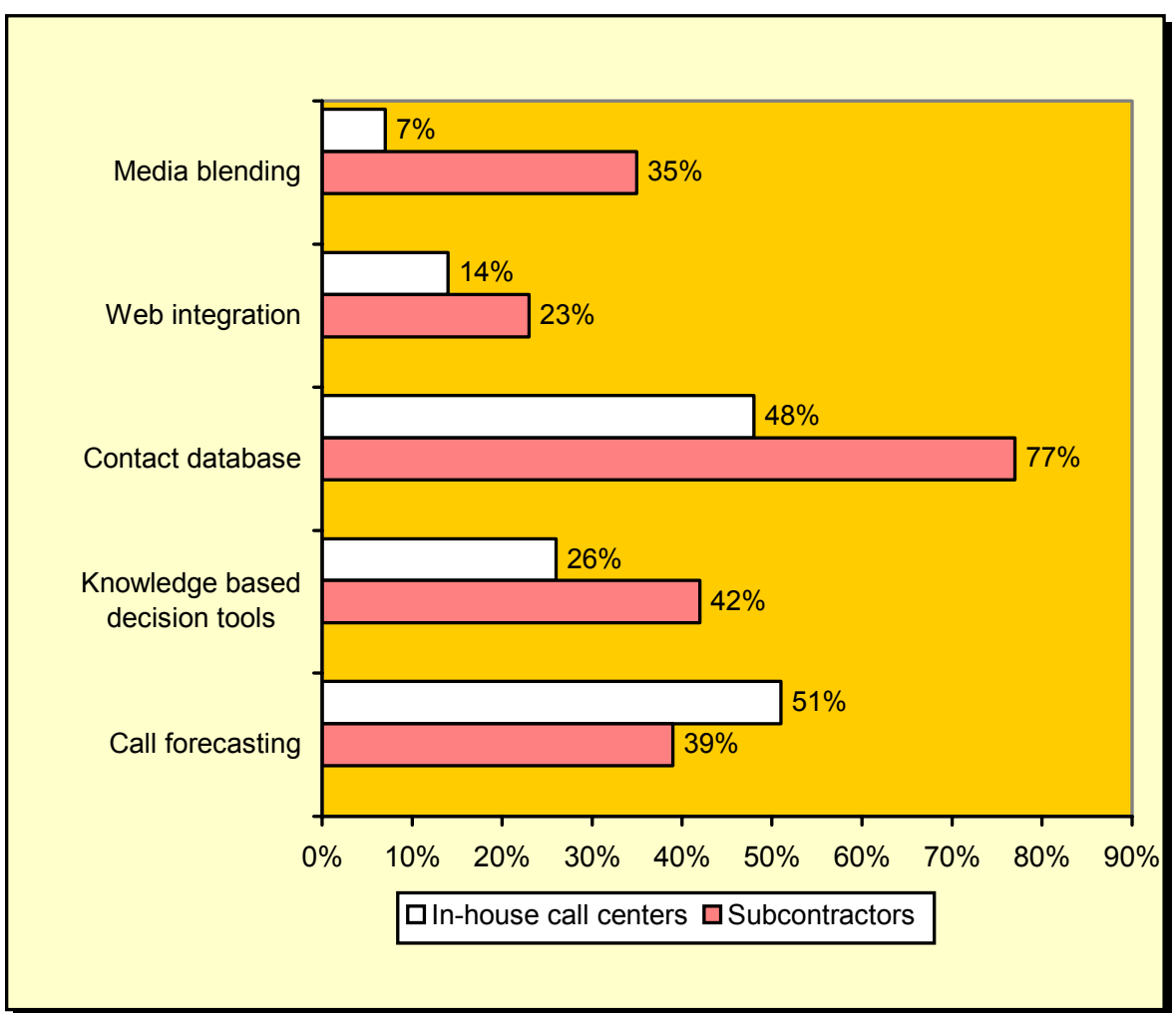

Overall, subcontractor call centers invest more in new, advanced technologies compared to in-house call centers. They use media blending (35 percent) and web integration like call back buttons, chat, co-browsing etc. (23 percent) to a greater extent. In addition, they are more likely to have a contact database with information on customers and contact history (77 percent) and knowledge based decision tools or expert systems (42 percent). Call forecasting, on the other hand, is more often found in in-house call centers (51 percent) than in subcontracting call centers (39 percent). Investments in new technologies also tend to follow the pattern we described above, with investments being higher in call centers with more advanced HR systems. For example, call centers with high involvement systems more often 
use IVR/VRU, speech recognition, web integration, and call forecasting compared to call centers with low-quality systems.

Overall, investments in technology constitute about 8 percent of total call center costs. The distribution of investment across technology categories includes: telecommunications hardware (2 percent), computer hardware (3 percent), and computer software (2 percent).

\subsection{Organization of Work: Discretion, Participation, and Teamwork}

The organization of work in call centers typically focuses on the individual employee (the agent) as the unit of analysis. Efficiency is measured by the number of calls handled per hour or by individual call handling time. The common use of these metrics is designed to maximize agent efficiency, and by doing so, revenues per call. The in-house call centers in this study handled on average 12 calls per hour, both for inbound and for outbound calls. The average call handling time (including processing the call) is about 270 seconds. Comparable information on efficiency is unavailable for subcontracting call centers.

With new technologies such as electronic customer databases and web-enablement, agents have greater need for discretion - to utilize the information in databases and to react quickly to customer preferences. One indicator of discretion at work is the extent to which employees are required to use scripted texts. The decision to use predetermined scripts in call center operations is based on several considerations, including how easy it is to standardize a certain kind of call and the ability to rely on other forms of performance management. According to our results, 27 percent of call centers reported no scripted use. However, in 25 percent of the call centers, script use was mandatory in most or all cases.

Relatively low use of scripts, however, does not necessarily translate into high levels of discretion for agents. We asked managers a series of questions about how much discretion (with options ranging from 'no discretion', 'a little discretion', to 'much discretion') agents have over particular aspects of their work, including daily tasks, work methods, and interactions with customers. From a managerial perspective, call center workers generally have some discretion at work, as Figure 3.2 reveals. For example, on average, 75 percent of managers perceived that their agents have much discretion over what they say to a customer; 71 percent said that agents have much discretion in handling additional requests or problems that arise unexpectedly; and 69 percent believed that agents have much discretion in settling customer complaints without referral to a supervisor or other expert. On the other hand, a small percentage of managers (14 percent) reported that their employees have much discretion over the design and use of new technology; only 22 percent said they have much discretion over the tools they use; and only 31 percent has much discretion over the daily tasks they do. Compared with the U.S. results, and to a lesser extent, Germany, the level of discretion among Dutch agents appears to be quite high. This suggests an overall lower level of standardization in Dutch call centers. Moreover, Dutch call 
center managers want to grant their employees more power: 75 percent of managers believe it is important to give call center agents more authority at work.

Figure 3.2

Call Center Agents' Discretion at Work

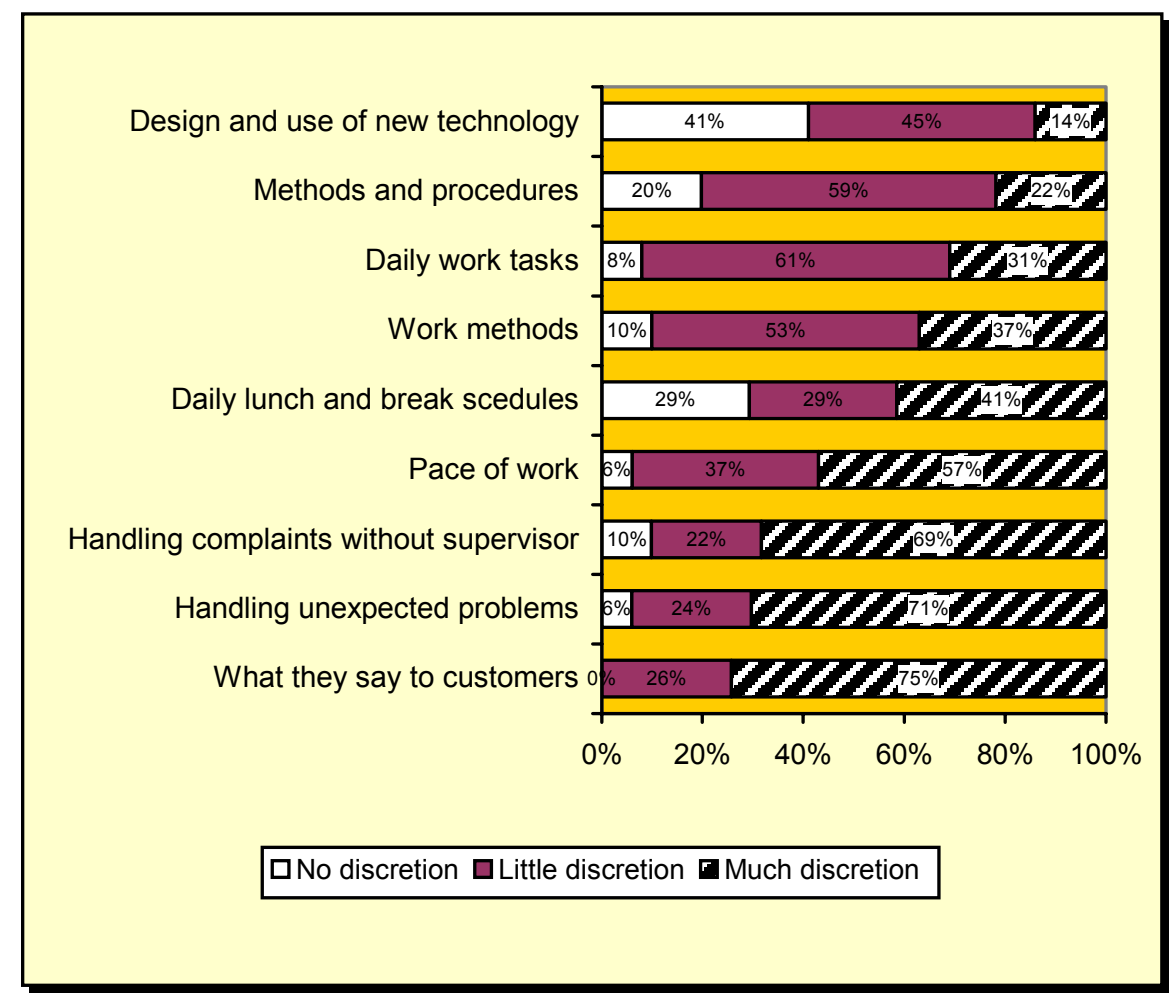

Monitoring of employees at work is another indicator of workers' discretion. Used for quality control, it might elicit strong reactions from agents because they feel they that there a low level of trust exists between them and management. Monitoring is a common feature in Dutch call center operations, with almost all Dutch call centers monitoring their agents. Interviews with call center managers show that monitoring is only used for agent feedback purposes. Agents know that a few specific calls per month are recorded, but they are unaware of when and which calls are being recorded. Supervisors can review the data, and evaluate it with the agents for coaching purposes. The frequency of monitoring varies across call centers. Figure 3.3 shows that in-house call centers in telecommunication, business services, and IT on average monitor their agents 5.5 times a month, whereas subcontractors monitor their agents roughly 4 times a month. In addition, agents working in call centers with low-quality HR systems are monitored more frequently than agents working in call centers with high involvement systems (2.8 versus 1.5 times a month). 
Figure 3.3

Frequency of Agent Monitoring by Month

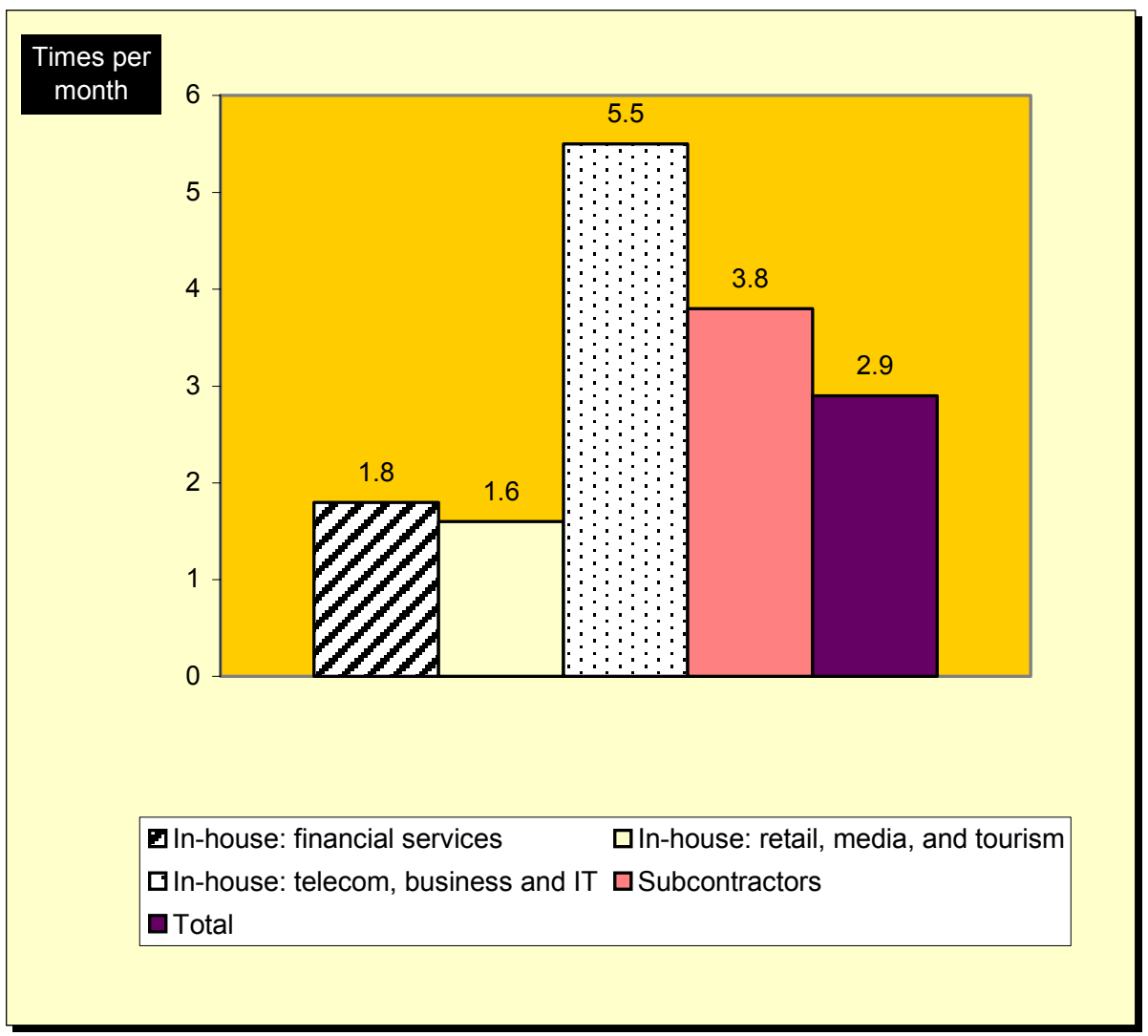

It should be noted that continuous agent monitoring is practically absent in the Netherlands. There are regulations regarding the recording of calls (Wet Bescherming Persoonsregistratie). Therefore, both call centers' employer organizations and unions are developing an agent monitoring protocol. So far, they have been unable to reach an agreement. Agents are not in favor of continuous monitoring: they feel that they are continually exposed at work and lack any privacy normally found in other workplaces. A substantial body of research has shown that continuous electronic monitoring increases job-related stress. ${ }^{14}$ In the U.S., this kind of monitoring, however, is quite common, especially for agents working at outsourced centers. Here, 73 percent of the workday is electronic monitored.

Although employee participation in management decisions and quality teams has long been viewed as important strategies for improving employee morale and performance, self-managing teams - agents working in teams that meet on a regular basis to decide on the division of tasks - and so-called quality circles are not very

14. Carayon, P. (1993). Effect of Electronic Performance Monitoring on Job Design and Worker Stress: Review of Literature and Conceptual Model. Human Factors, 35: 385-395. 
widespread in Dutch call centers. In a third of the call centers (some) agents work in self-managing teams (see Figure 3.4). Quality circles exist in roughly 40 percent of the call centers. Of those call centers that use quality circles, in only 8 percent do the majority of agents participate in these circles.

Figure 3.4

Functionally Flexible Work Practices

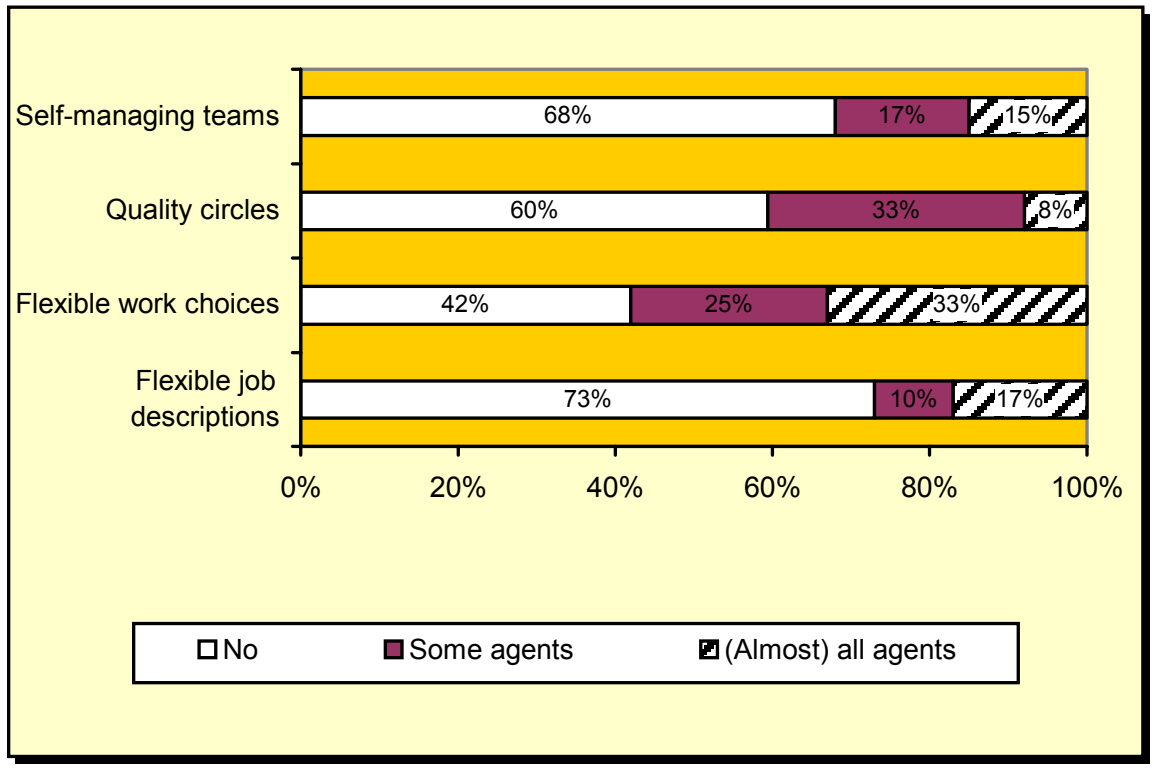

In addition, Figure 3.4 shows that the majority of call centers give their employees the choice to work in a flexible way. 33 percent offers flexible work choices to all their agents, whereas 25 percent has flexible work choices for only part of their workforces. Flexible job descriptions for agents, however, are relatively rare in Dutch call centers: 27 percent of call centers have flexible job descriptions, and only 17 percent use them for all of their agents.

Employee performance reviews are held in 96 percent of Dutch call centers. Figure 3.5 shows that 63 percent also administer employee satisfaction surveys. These surveys are used to a greater extent in financial services (86 percent) and in subcontracting call centers. Furthermore, all call centers with a high involvement HR system measure agent job satisfaction, whereas only 13 percent of call centers with a low-quality HR system do so. Most call centers administer employee job satisfaction surveys annually (57 percent). A small percentage, 11 percent, measure their agents' satisfaction once every three months, whereas an even smaller percentage, 6 percent, does so on a monthly basis. On average, agents rate their satisfaction with a 7.2 on a $0-10$ scale. 
Figure 3.5

Employee Job Satisfaction Surveys Administered

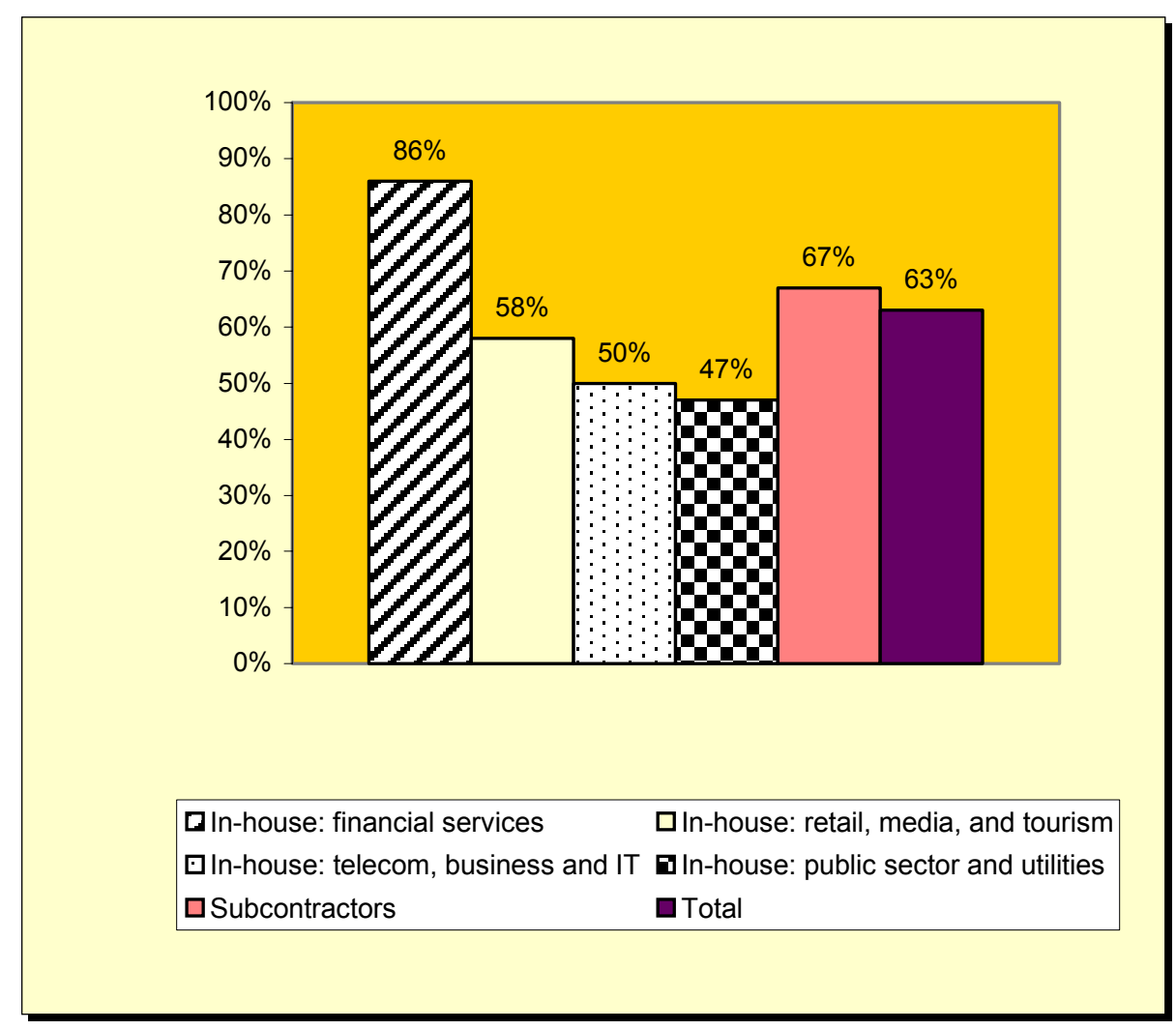

\subsection{Selection and Staffing Strategies}

In this section we examine the selection and staffing practices of call centers. These practices reflect the explicit strategies and locational decisions of managers, but are also influenced by local labor market conditions and the demographic characteristics of the local labor force. Here, we focus on demographic characteristics as age, education, and gender of the workforce, as well as the use of alternative patterns for use of full-time, part-time, and temporary workers. Our findings show that the workforce is more varied than expected, with higher age and education profiles than are commonly assumed for call center agents. The characteristics of the workforce also exhibit considerable variation across in-house and subcontracting call centers, and across call centers with different HR systems.

The majority of call center workers is between 25 and 50 years of age (see Figure 3.6). Approximately, 60 percent of Dutch agents are in this age category. 28 percent is less than 25 years of age, whereas 12 percent is 50 years or older. Subcontractors report having the youngest workforce: on average, 39 percent of their agents are 25 years or younger. Call centers with a low-quality HR system also have relatively young employees with 43 percent of their agents is the youngest age category. In 
contrast, call centers with a high involvement system on average employ 23 percent of agents in the youngest category. Call centers with intermediate HR systems have less variance in the age of their workforce than other call centers.

Figure 3.6

Age Distribution of Call Center Agents

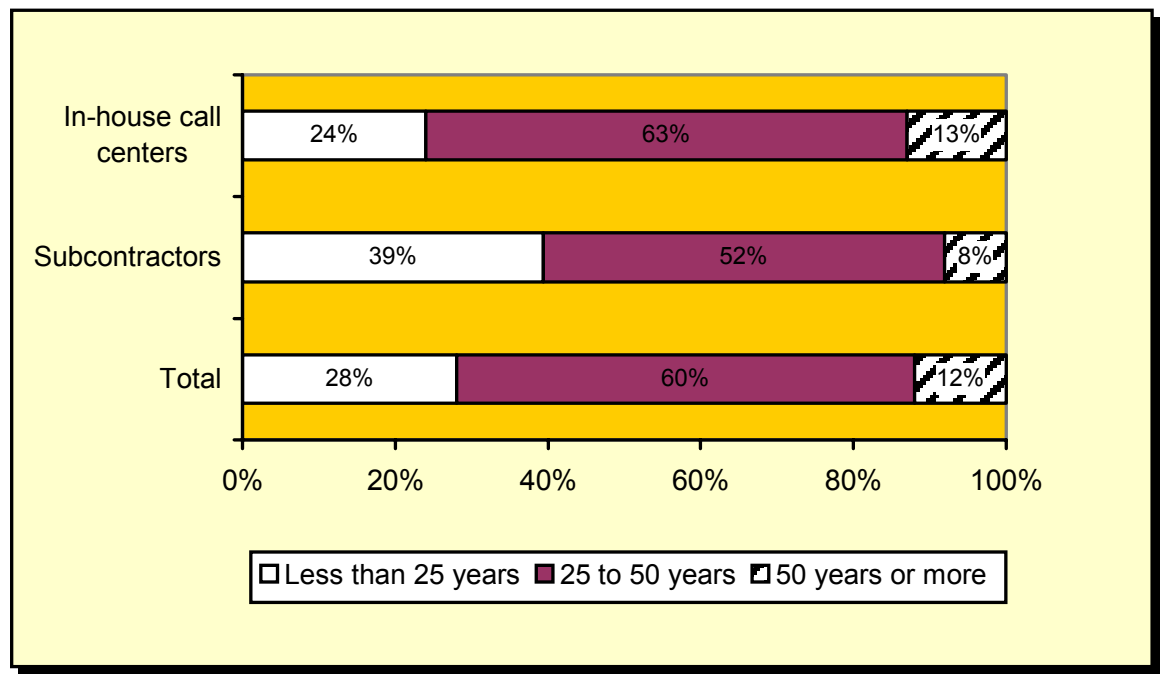

While call center jobs are often viewed as low skilled or 'clerical' jobs, in fact they typically require employees to be able to absorb changing product knowledge, manipulate databases, and have good communication skills. Thus, the educational level of call center workers is higher than is often portrayed in the popular press.

Figure 3.7

Educational Distribution of Call Center Agents

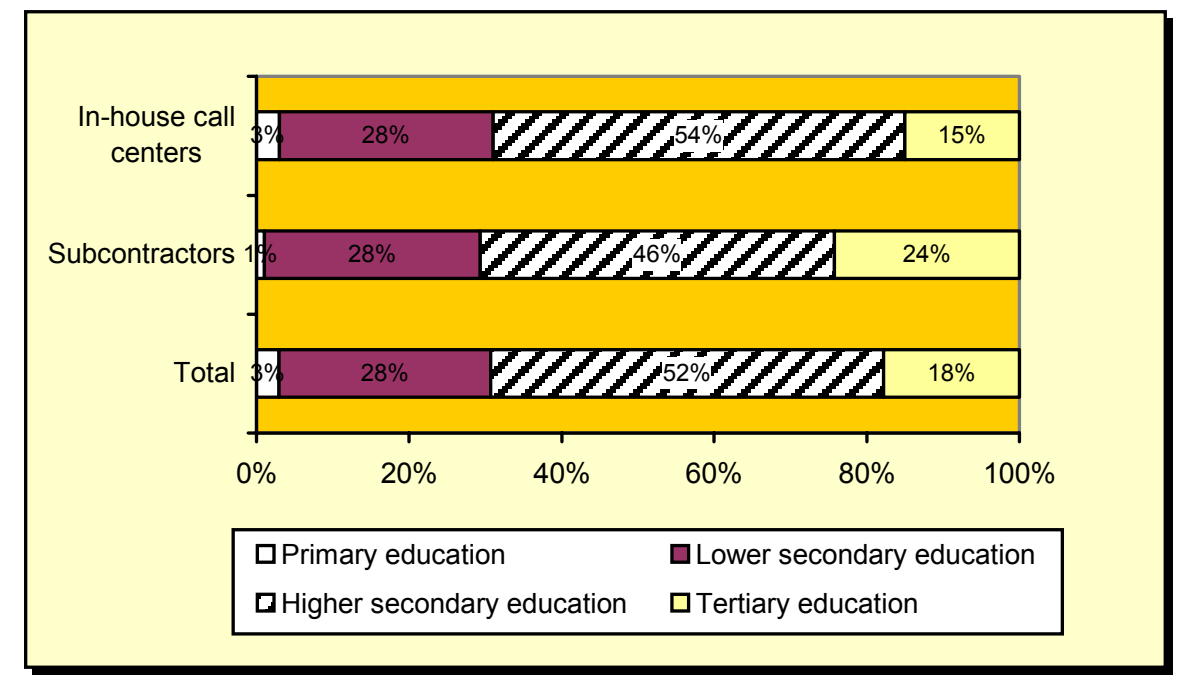


Figure 3.7 shows that 52 percent of Dutch call center agents have completed a higher level of secondary education (HAVO, VWO or MBO). Moreover, 18 percent of agents has a vocational college or university degree. The highest educational profiles are found among subcontracting call centers: on average, 24 percent of their agents holds a tertiary education degree. This anomaly may be related to the relatively young workforce employed by these call centers. Call centers with a high involvement HR system have an agent workforce with a relatively high education level: 97 percent of agents have completed more than primary education, and only 11 percent of the agent workforce has a lower secondary education (VMBO) certificate. In contrast, call centers with a low-quality system employ a higher percentage of less educated agents. For example, only 5 percent have only completed primary education, and 24 percent has completed a lower secondary education certificate. These educational qualifications are generally considered to be too low to enter the skilled labor market, which means that the level of complexity of work in call centers with a low-quality HR system must be relatively low.

Women constitute 70 percent of the call center workforce in this study, while men make up 30 percent. This gender distribution is consistent with the findings from the U.S. and German studies, were women represent 66 (U.S. study) and 72 (German study) percent of call center agents respectively. Women represent the highest proportion of the workforce in in-house call centers (73 percent), particularly in the retail, media, and tourism industry (76 percent). Women also make up a disproportionate percentage of agents in call centers with a high involvement HR system (75 percent).

Figure 3.8

Gender Distribution of Call Center Agents

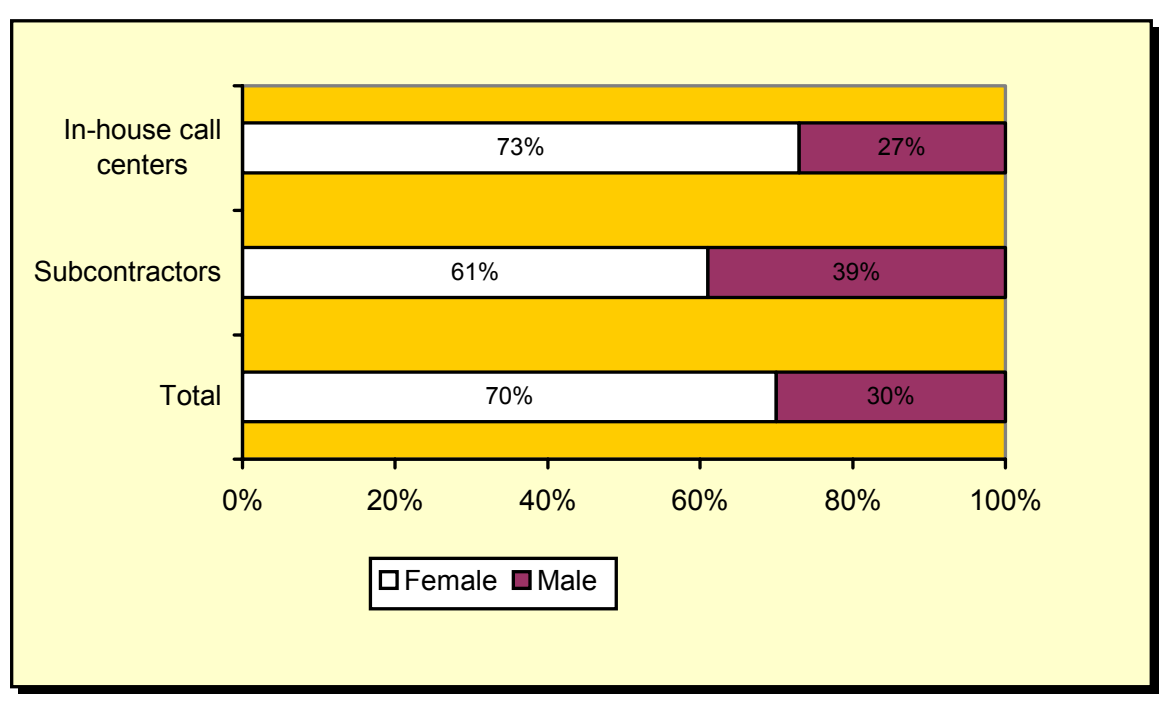


Agent work schedules also vary across call center categories. Figure 3.9 shows that on average, Dutch call center agents work 26 hours per week, with a range of 21 hours per week for agents in subcontracting call centers and 30 hours per week for those in the in-house financial services industry. In addition, agents employed by call centers with a high involvement HR system work more (31 hours per week) than agents in call centers with a low-quality system ( 21 hours per week).

Figure 3.9

Average Weekly Work Hours of Call Center Agents

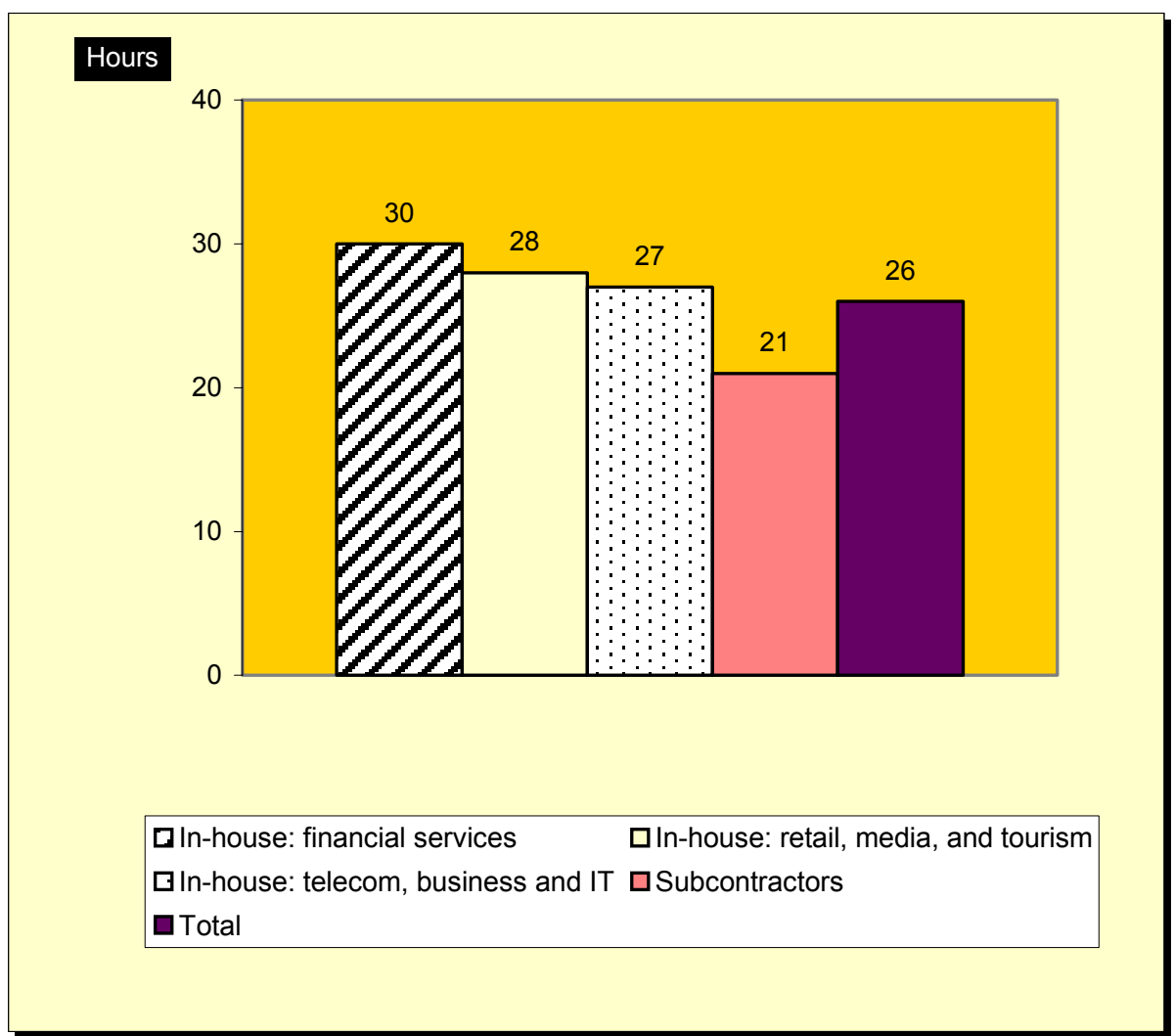

Figure 3.10 shows that in general, 36 percent of the agents have a full-time job, and 64 percent a part-time job. Since a large majority of call center employees are female, this outcome is unsurprising. Many Dutch women stop working after their first child is born, or switch to part-time work. This has triggered researchers to label the Netherlands as 'the only part-time economy in the world'. ${ }^{15}$ By comparison, in the U.S., most call center employees work on a full-time basis: on average they work 40 hours per week. In Germany, 43 percent of the agents hold a part-time job. In the Netherlands, in-house call centers employ almost twice as many full-timers as subcontractors. Finally, call centers with a high involvement HR system employ more

15. Freeman, R. B. (1998). War of the Models: Which Labor Market Institutions for the 21st Century? Labor Economics, 5 (1): 1-24. 
full-time agents (41 percent) than call centers with a low-quality system ( 25 percent). Some call center managers interviewed for this study explained that they specifically do not hire full-time agents, because they think this type of work is too demanding to expect an employee to be on the phone for 40 hours a week.

Figure 3.10

Distribution of Full-Time and Part-Time Working Call Center Agents

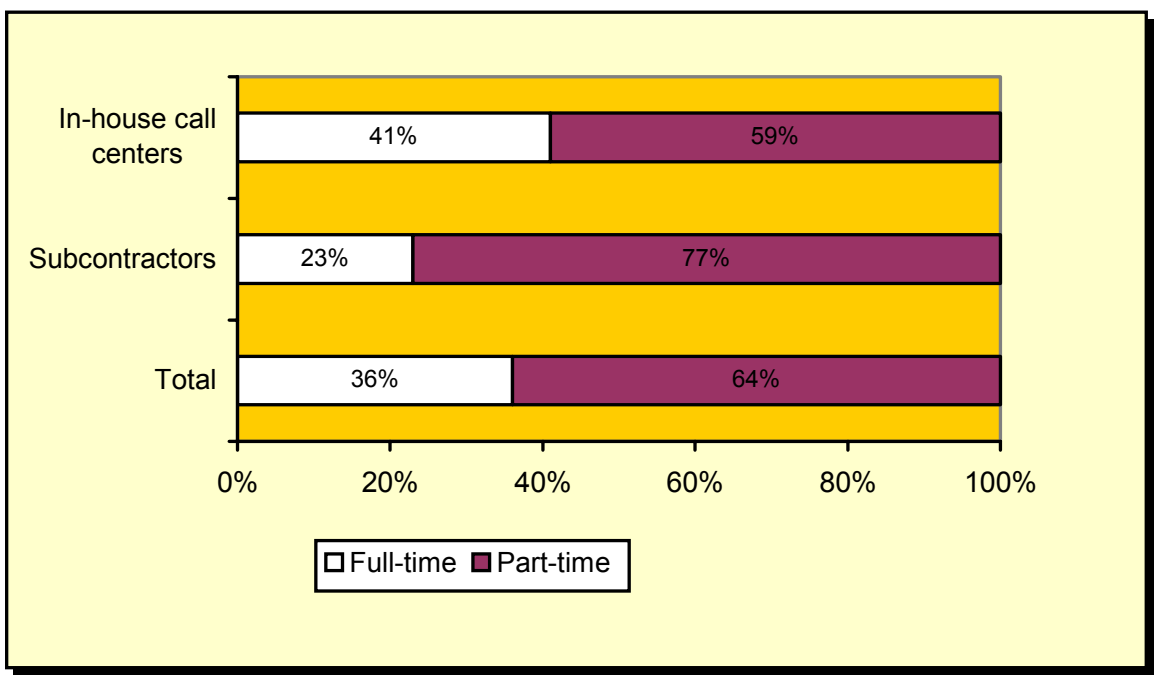

Another way to analyze staffing practices is to focus on the percent of the workforce that is temporary. ${ }^{16}$ This represents a less traditional approach to staffing, and provides employees with less security about their employment. On average, 21 percent of call center agents has a temporary contract. Of these temporary workers, 80 percent works part-time. Call center managers identified several reasons to explain why they work with temporary agents. The most prominent one is that temporary contracts are used during a probationary period before giving agents a permanent contract. Some call centers employ temporary agents to save costs, whereas only a minority mentions the use of temporary contracts to deal with unexpected peaks in workload or to replace absent employees. Eventually, 56 percent of temporary call center agents receive a permanent contract.

The selectivity of employers in their hiring practices is one indicator of whether they are attempting to compete on the basis of quality service. The 'select rate' is the percentage of employees who are actually hired compared to the total pool of applicants. The lower the select rate, the more selective the employer is in hiring new applicants. In this study, we found that the average select rate for call centers is 47 percent, about 1 worker hired for every 2.1 applicants. This select rate is much higher

16. Temporary agents are on the payroll of the call center, in contrast to flexible workers, who are not employed by the call center itself but are on the temporary work agency's payroll. In the next section, we will focus on the position of these flexible or temporary agency workers. 
compared with results from the U.S. (28 percent) and Germany (22 percent). Considering Dutch in-house and subcontracted call centers, there are no large differences.

Figure 3.11 shows the different selection techniques call centers use when they hire new agents. 83 percent have personal job interviews with applicants. Job interviews by phone are less popular; 31 percent uses them to select new agents. In almost a third of the call centers, new agents are involved in role-playing, such as answering realistic test calls or emails. Aptitude or personality assessments are used by 16 percent of the call centers, whereas 15 percent test the applicants' writing and spelling skills. Finally, 3 percent of the call centers require their new employees to pass a formal exam.

Figure 3.11

Selection Techniques for New Call Center Agents

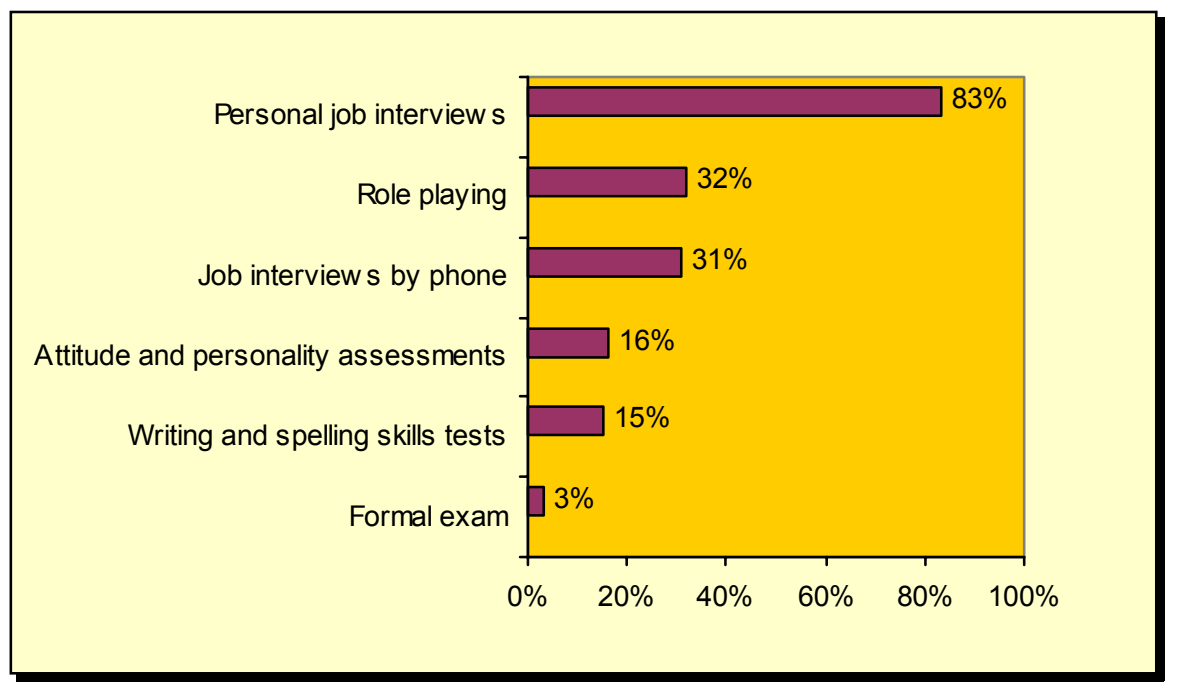

\subsection{Role of Temporary Work Agencies}

In the Netherlands, temporary work agencies (uitzendbureaus) play a significant role in call center employment. For example, about 65 percent of Dutch call centers work with agents who are employed by these agencies. In Germany, this percentage is much lower: 15 percent. Part of the difference can be explained by the unique nature of contingent Dutch employment laws. Introduced in 1999, the Flexibility and Security Act negotiated the positive and negative aspects of contingent work for both employers and employees. ${ }^{17}$ 'Limited duration contracts', also known as definite contracts, are converted into an open-ended contract if the contract is extended three times or continues for three years. Although the first twenty-six weeks of a flexible

17. B. Koene, J. Paauwe \& J. Groenewegen (2004). Understanding the Development of Temporary Agency Work in Europe. Human Resource Management Journal 14 (3) p. 5373. 
worker's contract are unregulated, following this period, the relationship between the worker and the temporary work agency is recognized as an employment contract. ${ }^{18}$ The regulations of the Flexibility and Security Act can be adapted to the particular needs of an industry if employer organizations and unions agree upon it in a collective agreement, as illustrated by the collective agreement for temporary agency workers (CAO voor uitzendkrachten). In this collective agreement, three stages are distinguished:

- Stage A: a period of 78 weeks in which one starts working as a flexible worker;

- Stage B: after 26 weeks of work in Stage A, Stage B is a period of definite contracts for 2 years (or eight definite contracts) at most. Interruptions of less than 13 weeks are allowed;

- Stage C: indefinite period with an open-ended contract. ${ }^{18}$

In addition, the collective agreement for flexible workers provides for a pension fund, a training interview at the end of the 26 weeks of employment, and a percentage of salary costs committed to a training fund. Thus, the collective agreement establishes some protections and a minimum level for working conditions for temporary agency workers.

Figure 3.12

Average Tenure in Months for Temporary Agency Workers

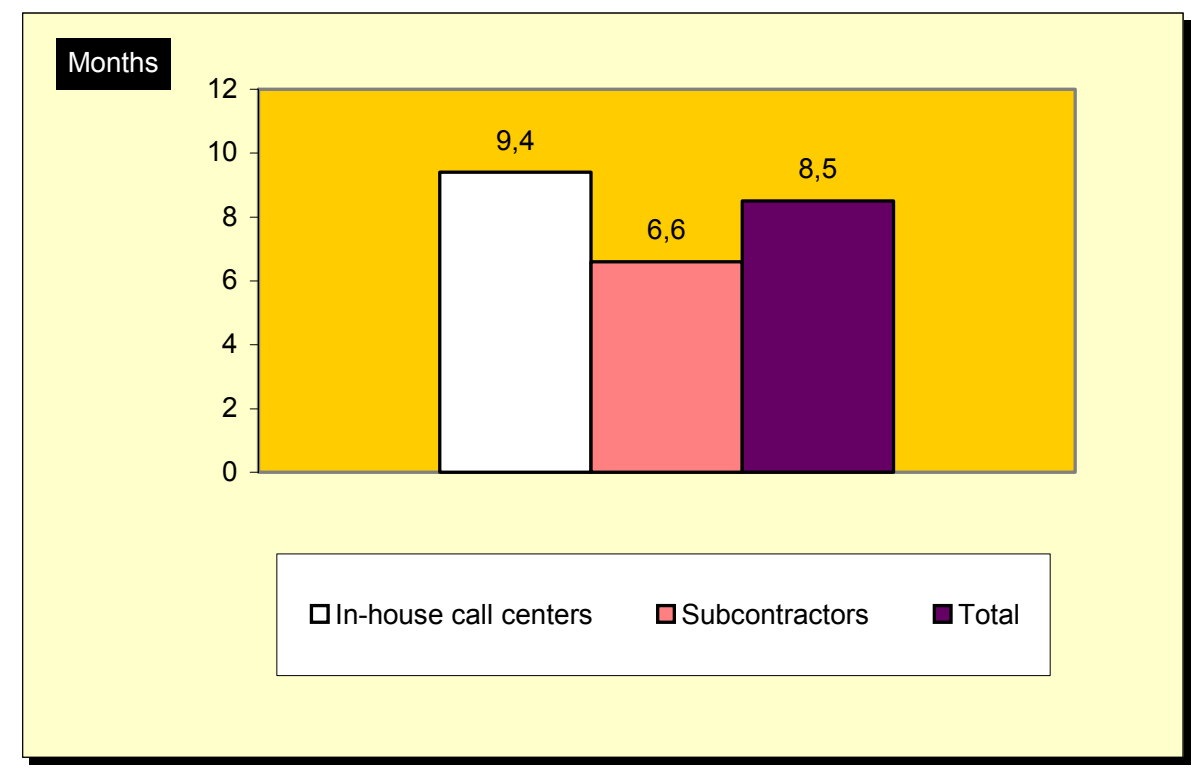

Overall, 19 percent of the agents is employed by a temporary work agency. In-house call centers have fewer flexible agents than subcontracting call centers: 16 versus 25 percent. In addition, call centers with a low-quality HR system employ a significantly

18. Storrie D. (2001), Temporary Agency Work in the European Union. Consolidated Report. Luxembourg: European Foundation for the Improvement of Working Life and Living Conditions. 
higher percentage of flexible agents (36 percent) than call centers with a high involvement system (9 percent).

Flexible agents, on average, are employed for 23 hours per week. Compared with regular call center agents, temporary agency workers in in-house call centers work more hours ( 25 hours per week) than flexible agents in subcontracting call centers (19 hours per week). Figure 3.12 shows that flexible agents normally have a relative short tenure in a call center: 8.5 months on average. For in-house call centers, this period is somewhat longer (9.4 months) than in subcontracting call centers (6.6 months). About a third of all temporary agency workers eventually receives a contract at the call center they work in.

In general, call centers mainly choose to work with flexible workers because they want to handle the unexpected workload peaks or replace absent employees. Interviews with temporary agency managers revealed that most temp agencies offer a range of services for call centers: recruitment and selection, training, and evaluation. Most call centers work with one or two dedicated temp agencies, although some use multiple agencies to take advantage of the competition between them. Sometimes, the temporary agency is even located on site.

Figure 3.13

Difficulties Encountered to Recruit New Agents

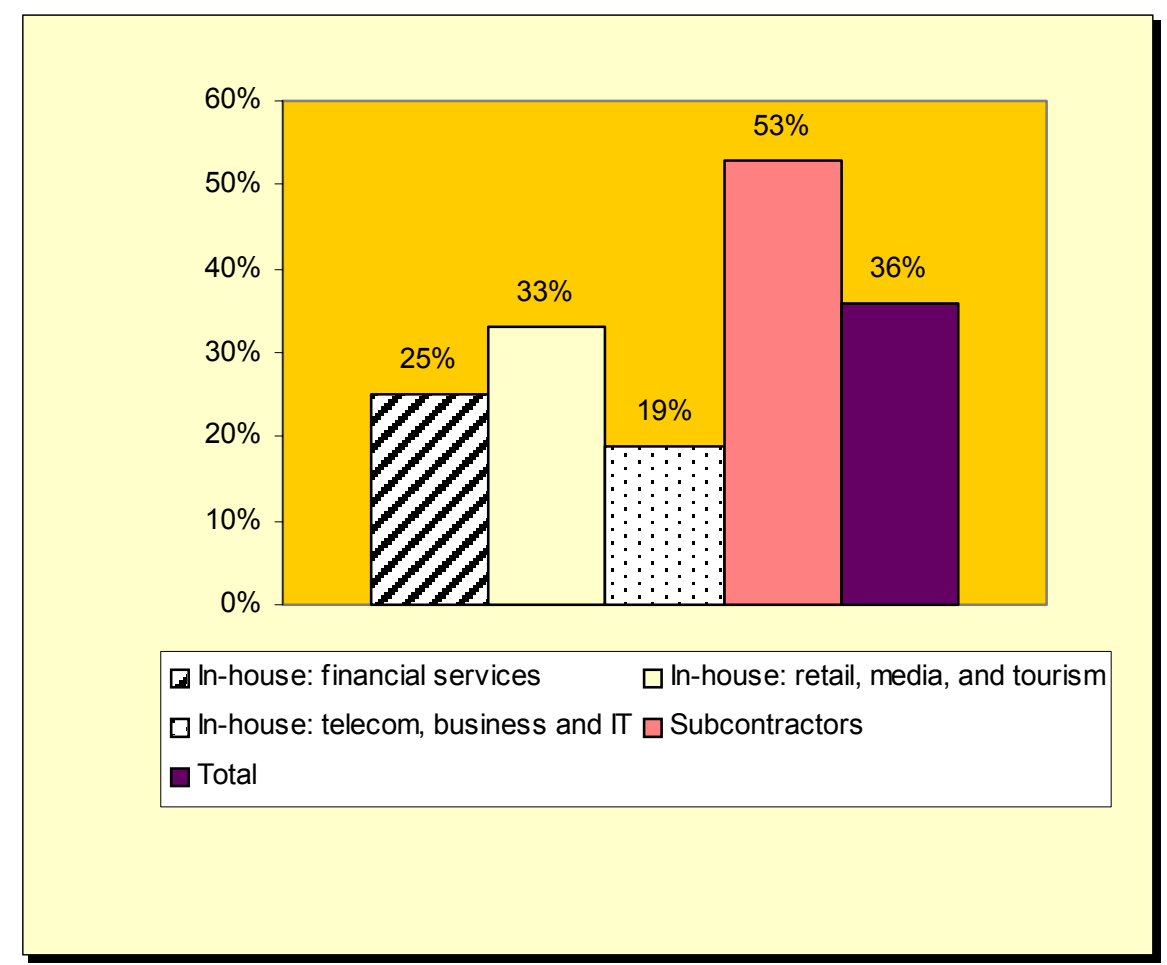


Recruitment and selection is perhaps the most obvious function of temporary agencies, as this often is quite difficult for call centers. Figure 3.13 shows that 36 percent of the Dutch call centers encounter difficulties in recruiting new agents. Subcontractors have particularly severe problems with attracting applicants (53 percent). In-house call centers find it easier to find new agents. Only 19 percent of the in-house call centers in telecommunication, business services, and IT and 25 percent in financial services said that recruitment was difficult. In addition, call centers with a low-quality HR system experience less difficulty with agent recruitment than call centers with a high involvement system. One explanation for this difference is the presence of higher educational standards in the latter.

Another indicator of recruitment difficulty is the number of days a vacancy remains unfilled. Figure 3.14 illustrates that subcontractors experience more problems in selecting new agents, at least when it comes to recruiting new outbound agents. As shown in Chapter 2, subcontractors undertake a lot of outbound work. It takes them on average 36 days to fill an outbound vacancy. In in-house call centers, this period is twice as short. Inbound agents are less difficult to recruit. On average, a vacancy is filled in 17 days in subcontracting call centers. In in-house call centers, it takes 22 days to fill an inbound position.

Figure 3.14

Average Number of Days a Vacancy Remains Unfilled

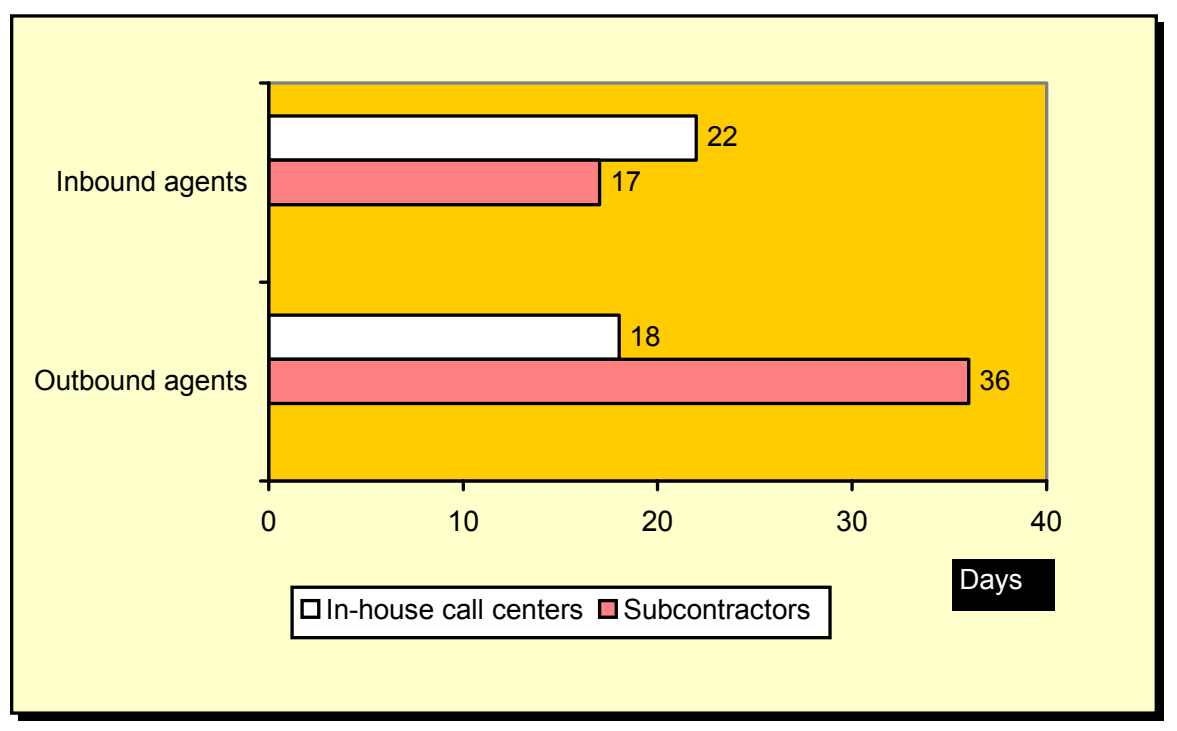

All in all, a majority of Dutch call centers use a third party to assist with recruiting and selecting new agents (see Figure 3.15). A high percentage of financial services call centers (95 percent) use a third party compared to the other in-house category (48 percent in retail, media, and tourism). In contrast, 79 percent of subcontractors receive some assistance in recruitment and selection. However, only 14 percent of Dutch call centers hire third parties to do all their agent recruitment and selection. 
Figure 3.15

Assistance from Third Parties to Recruit New Agents

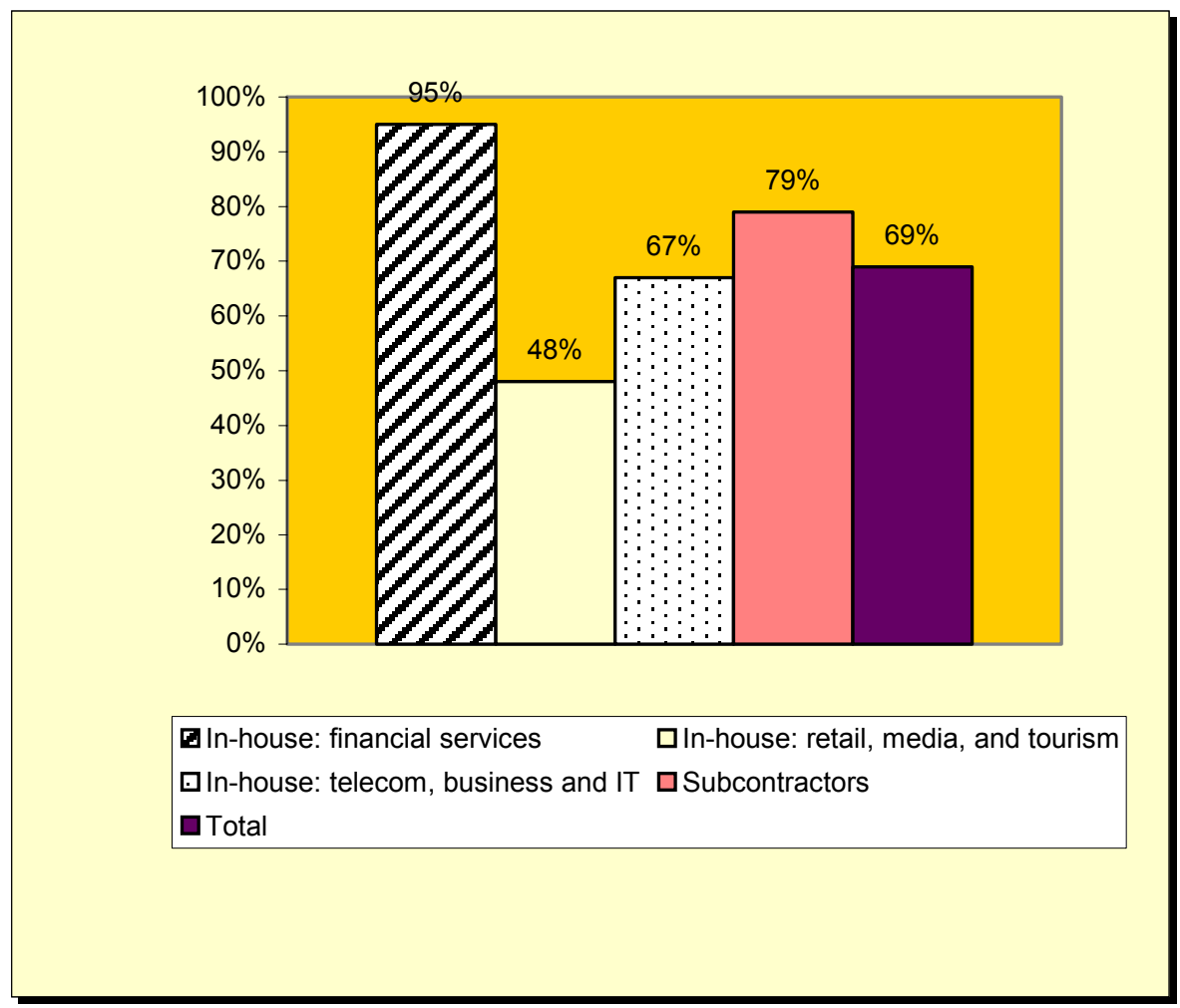

Interviews with both temporary agency managers and call center managers show that contracts between the two parties almost always include terms on prices, service levels (performance) and delivery rate: how many agents will be recruited and in what time frame? The call center provides the agency with a detailed agent profile what kind of agent is needed - after which the temporary agency makes the first selection. It depends on the call center whether they or the agency is responsible for the rest of the recruitment process. Some call center managers told us they had negative experiences with temp agencies' selection procedures, and therefore choose to do the interviews and evaluations themselves. Others, however, leave the whole selection process to the temporary work agency. Generally, these temporary agencies tend to specialize in call center work. Next to a normal job interview, candidates are tested on typing accuracy and dealing with telephone calls. Usually, several role plays are done, like handling a complaint and dealing with a stressful situation. Depending on the type of job, other skills, such as foreign language ability or technical knowledge, is also evaluated.

In some cases, specialized temporary agencies also provide the initial training of the newly hired agents. This usually is a basic training in telephone techniques and customer service. For example, Randstad Callflex even set up a 'Call Center Aca- 
demy', in which flexible agents may enroll to obtain a certificate. Most call centers prefer to train their agents themselves, though. Finally, some specialized temporary agencies participate in the ongoing performance evaluation of call center agents, which involves monitoring and coaching of agents. Feedback is usually given together with the direct supervisor of the agent. 



\section{Wages, Working Conditions, and Personnel Turnover}

\subsection{Pay Levels and Total Compensation}

The differences in patterns of work organization and staffing and selection across call centers serving different industries are also reflected in compensation strategies and pay differentials. Figure 4.1 shows the gross hourly pay in euros for call center agents and temporary agency workers. In-house call centers on average pay about 3 euros per hour more than subcontractors. In addition, call centers with high involvement HR systems pay their agents significantly more (€ 16.20 per hour) than call centers with low-quality systems ( $€ 12.90$ per hour).

Figure 4.1

Average Hourly Pay of Call Center Agents and Temporary Agency Workers (in Euros)

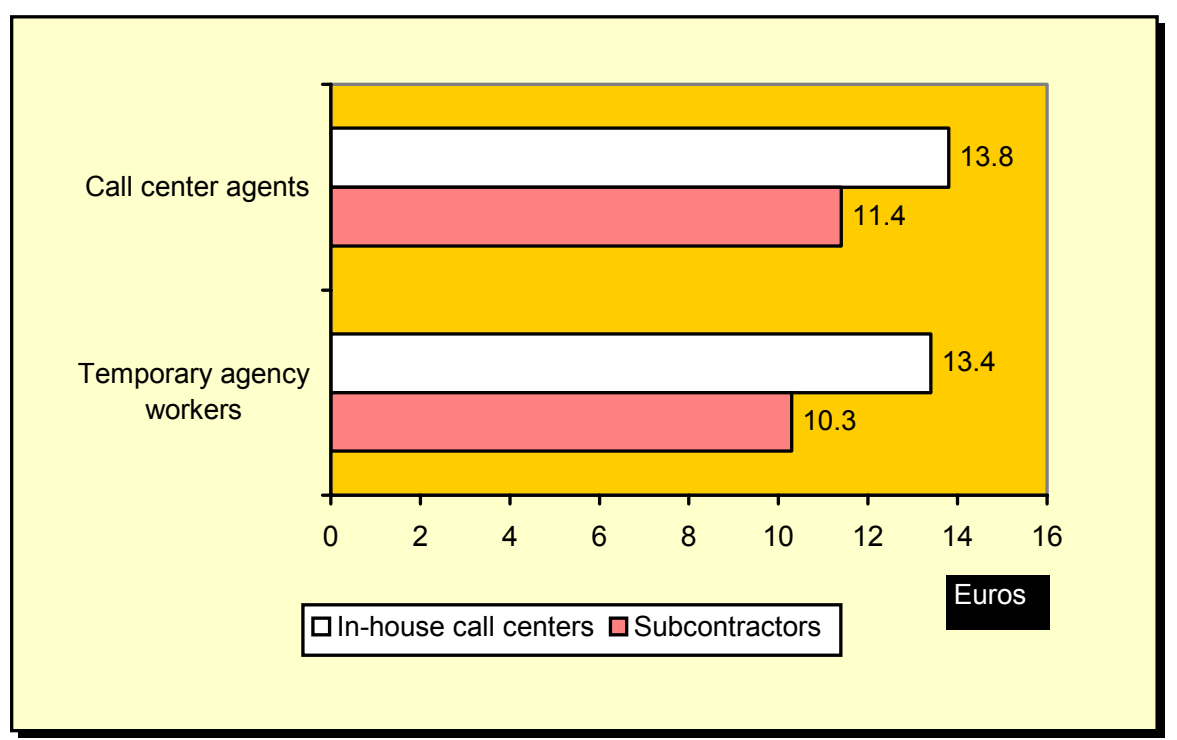

Figure 4.1 also illustrates that temporary agency workers earn less than regular call center agents. In in-house call centers, the difference is only $€ 0.40$ per hour, whereas flexible agents working in subcontracting call centers on average earn $€$ 1.10 per hour less.

The differences in pay level between in-house and subcontracting call centers are also present at the management level. Figure 4.2 shows that team leaders in inhouse call centers on average earn more than $€ 2,500$.-- gross per month, whereas team leaders working in outsourced centers are paid almost $€ 2,120$.-- per month. Supervisors are paid more ( $€ 2,800$.-- a month) when working in in-house call centers than those in subcontracting call centers (roughly $€ 2,000$.--). Finally, contact center 
managers in in-house call centers on average earn almost $€ 700$ per month more than managers in subcontracting call centers.

Figure 4.2

Average Monthly Pay of Team Leaders, Supervisors, and Managers

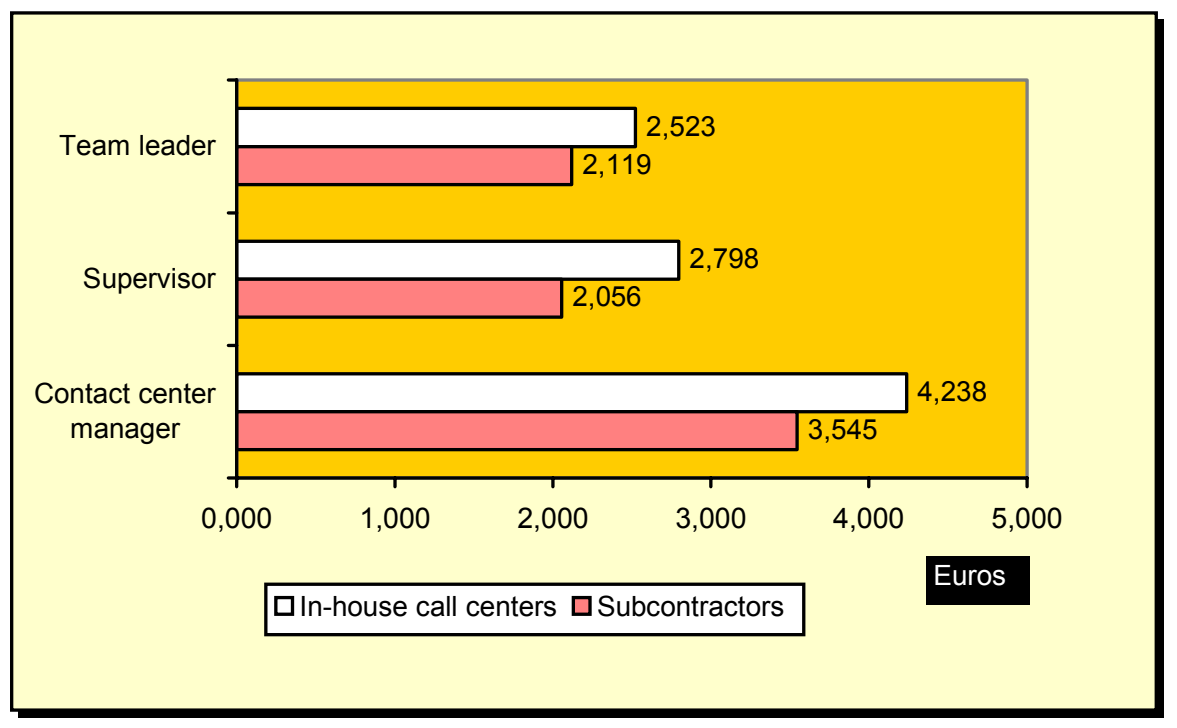

Considering the pay levels of the core call center employees, Table 4.1 reveals that performance-based pay is in limited use in the Netherlands: 63 percent of the call centers do not use any performance-based pay for their agents. It is perhaps no surprise that performance-based pay is also uncommon in the public sector and utilities industry, with only 13 percent of call centers using it for their agents. Call centers in the financial services on the other hand, are quite familiar with performance-based pay (53 percent). When call centers do pay their agents on the basis of performance, it is usually based on individual performance alone (19 percent) as opposed to group performance. This pattern is quite strong among subcontractors: 27 percent base their agent pay on individual performance. Both individual and team performance is the basis of agent pay in only 14 percent of Dutch call centers; financial services taking the lead with 32 percent. Performance pay based on team performance alone is very uncommon: only 5 percent of call centers use this type of performance-based agent pay.

With respect to call center HR systems, it is notable that 25 percent of call centers with low-quality HR systems have agent pay based on individual performance, whereas 31 percent of the call centers with high involvement systems base their agent pay on both individual and team performance. Generally, call centers with an intermediate HR system do not have performance-based pay (68 percent). 
Table 4.1

Performance-based Pay

\begin{tabular}{|c|c|c|c|c|c|c|}
\hline & $\begin{array}{r}\text { In-house } \\
\text { financial } \\
\text { services } \\
\%\end{array}$ & $\begin{array}{r}\text { In-house } \\
\text { retail, } \\
\text { media and } \\
\text { tourism } \\
\%\end{array}$ & $\begin{array}{r}\text { In-house } \\
\text { telecom, } \\
\text { business } \\
\text { and IT } \\
\%\end{array}$ & $\begin{array}{r}\text { In-house } \\
\text { public } \\
\text { sector } \\
\text { and } \\
\text { utilities } \\
\%\end{array}$ & $\begin{array}{r}\text { Sub } \\
\text { contrac- } \\
\text { tors } \\
\\
\%\end{array}$ & Total \\
\hline $\begin{array}{l}\text { Individual performance } \\
\text { Team performance } \\
\text { Both individual and team } \\
\text { No performance pay }\end{array}$ & $\begin{array}{r}16 \\
5 \\
32 \\
47\end{array}$ & $\begin{array}{r}24 \\
3 \\
7 \\
66\end{array}$ & $\begin{array}{l}18 \\
12 \\
12 \\
59\end{array}$ & $\begin{array}{r}0 \\
0 \\
13 \\
87\end{array}$ & $\begin{array}{r}27 \\
3 \\
10 \\
60\end{array}$ & $\begin{array}{r}19 \\
5 \\
14 \\
63\end{array}$ \\
\hline
\end{tabular}

Figure 4.3 shows the dimensions for performance pay. In 21 percent of the call centers that have with this kind of agent pay, pay level is based on sales performance. Roughly the same percentage of call centers works with performance pay based on quality or on productivity. Customer satisfaction determines the pay level of agents in only 7 percent of call centers with performance-based pay.

Figure 4.3

Factors on Which Performance Pay is Based

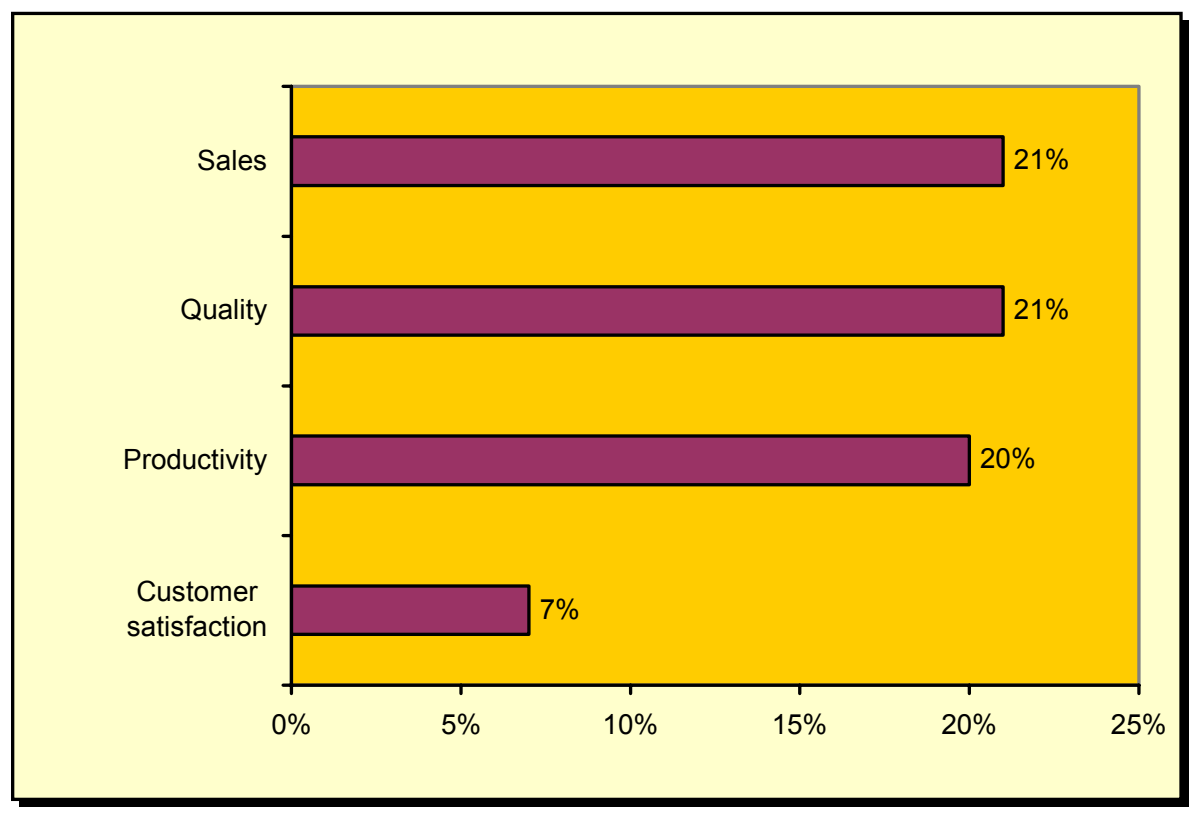

Some call center managers explained in interviews for this stuffy that they use other types of incentives to motivate their agents. When specific targets are reached, agents (or teams of agents) receive small presents like theatre or football tickets. In a 
large subcontracting call center, agents get points for reaching outbound targets. These points can be used to buy presents or holiday trips from a catalogue.

Table 4.2

Wage Supplements and Average Percentage of Supplement

\begin{tabular}{lrr}
\hline & Yes & $\begin{array}{r}\text { Average supplement } \\
\text { percentage } \\
\%\end{array}$ \\
\hline Working in the evenings & $\%$ & \\
Working on Saturdays & 38 & 28 \\
Working on Sundays & 35 & 76 \\
Working on holidays & 25 & 85 \\
\hline
\end{tabular}

Table 4.2 shows that some call centers compensate their agents with extra pay for working evenings (38 percent), on Saturdays (35 percent), on Sundays (25 percent), and on official holidays (31 percent). The supplement percentages range from 28 percent for working in the evenings to 85 percent for working on holidays.

Figure 4.4

Fringe Benefits Offered

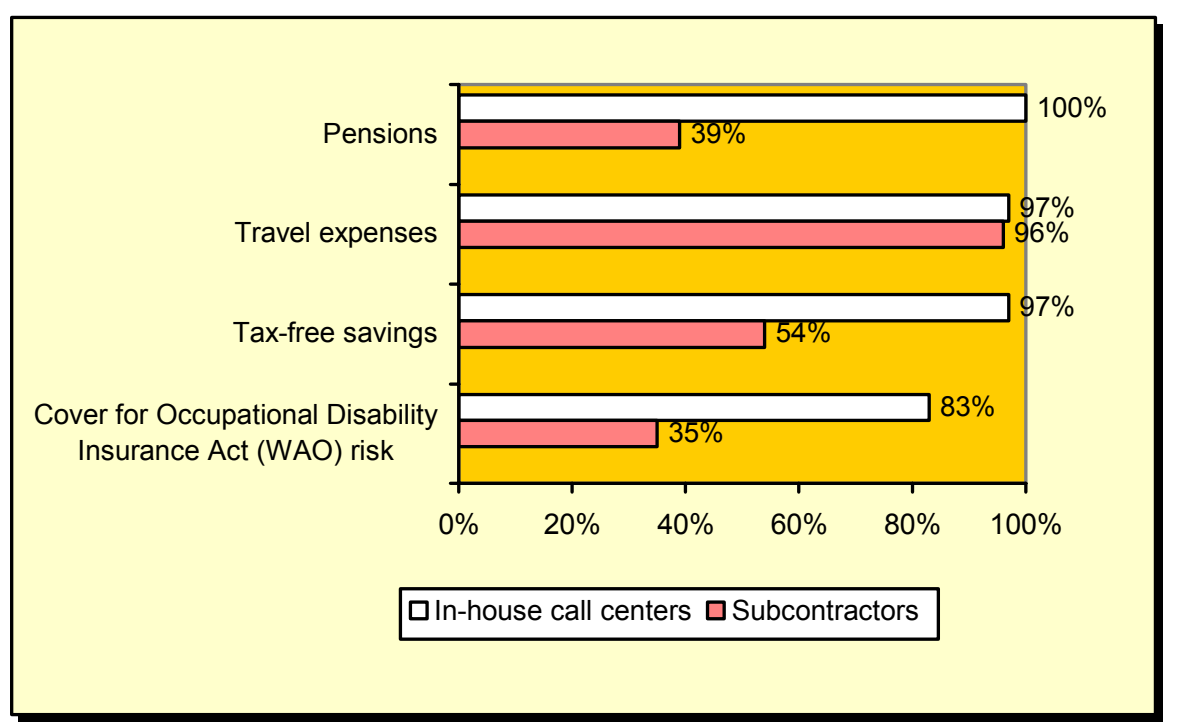

Call centers also offer their agents a range of fringe benefits. Again, agents working in in-house call centers receive more fringe benefits compared with those in subcontracting call centers (see Figure 4.4). All the in-house respondents offered their agents pensions, whereas only 39 percent of subcontractors do so. Tax-free savings are offered by 97 percent of in-house call centers and by 54 percent of subcontractors. And 83 percent of in-house call centers cover the Occupational Disability Insurance Act (WAO) risk, whereas only 35 percent of subcontractors cover 
this risk. Moreover, call centers with a high involvement HR system provide their agents with more fringe benefits than call centers with a low-quality system, with the exception of travel expenses. Travel expenses are covered by all call centers to the same extent (about 97 percent). In total, personnel costs like wages, compensations, and fringe benefits make up about 71 percent of a call center's budget.

\subsection{Working Conditions}

Working conditions in Dutch call centers are to some extent bound by the law (Arbowet). This law establishes minimum standards for working conditions with regard to health and safety, and is enforced by the Factory Inspectorate (Arbeidsinspectie). Regulations about work seats and absenteeism are among those strictly enforced. Firms are obliged to write up their firm-specific regulations in a document called Arbobeleid. Figure 4.5 shows that 94 percent of in-house call centers and 78 percent of subcontractors have introduced such formal regulations. In addition, these regulations are present more frequently in call centers with high involvement HR systems (94 percent) than in call centers with low- quality systems (77 percent).

Figure 4.5

Formal Regulations on Working Conditions (Arbobeleid)

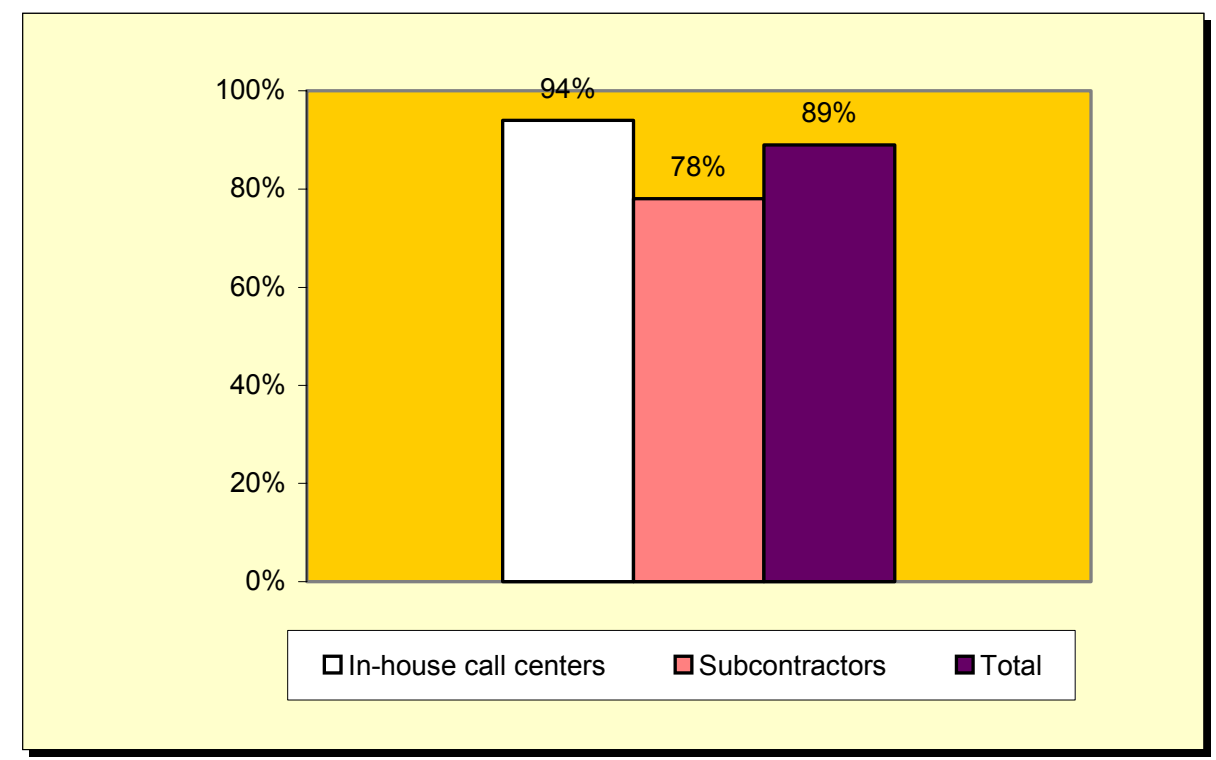

Table 4.3 shows some work seats characteristics. The average Dutch call center has 97 work seats. Subcontracting call centers are larger: they on average have 147 seats, whereas in-house call centers in retail, media, and tourism on average only have 64 seats. Work seats usually are about $7 \mathrm{~m}^{2}$ in size. Seats in subcontracting call centers appear to be somewhat smaller than seats in in-house call centers. 66 percent of call centers use partition walls to separate work seats at their site. Partition walls are most often used in financial services (90 percent) and less often in 
telecommunications, business services, and IT (40 percent). Almost 80 percent of the work seats are adjustable in height, although this is reduced to 69 percent when considering outsourced centers. The same holds for air-conditioning. In addition, airconditioning is most common in financial services call centers (90 percent).

Table 4.3

Work Seat Characteristics

\begin{tabular}{|c|c|c|c|c|}
\hline $\begin{array}{l}\text { In-house } \\
\text { financial } \\
\text { services }\end{array}$ & $\begin{array}{r}\text { In-house } \\
\text { retail, } \\
\text { media and } \\
\text { tourism }\end{array}$ & $\begin{array}{l}\text { In-house } \\
\text { telecom, } \\
\text { business, } \\
\text { and IT }\end{array}$ & $\begin{array}{r}\text { Sub- } \\
\text { contrac- } \\
\text { tors }\end{array}$ & Total \\
\hline
\end{tabular}

\begin{tabular}{lrrrrr} 
& & & & & \\
Average number of seats & 117 & 64 & 81 & 147 & 97 \\
Average size of work seat $\left(\mathrm{m}^{2}\right)$ & 7.3 & 7.5 & - & 6.5 & 7.2 \\
Use of partition walls (\%) & 90 & 59 & 40 & 69 & 66 \\
Adjustable in height (\%) & 75 & 72 & 80 & 69 & 79 \\
Air-conditioning (\%) & 90 & 82 & - & 69 & 80 \\
Teleworking (\%) & 5 & 14 & 0 & 11 & 9 \\
\hline
\end{tabular}

- Insufficient observations

Finally, Table 4.3 shows that only a minority of call centers gives their agents the opportunity to work at home, more commonly referred to as 'remote agents'. Remote agents are most commonly found in the retail, media, and tourism industry, and in subcontracting call centers. We found a similar level of use comparing both call centers with low-quality HR systems as well as call centers with high involvement systems (13 percent). In comparison, call centers with an intermediate HR system reported less use of remote agents ( 7 percent).

Figure 4.6

Use of Flat Screens

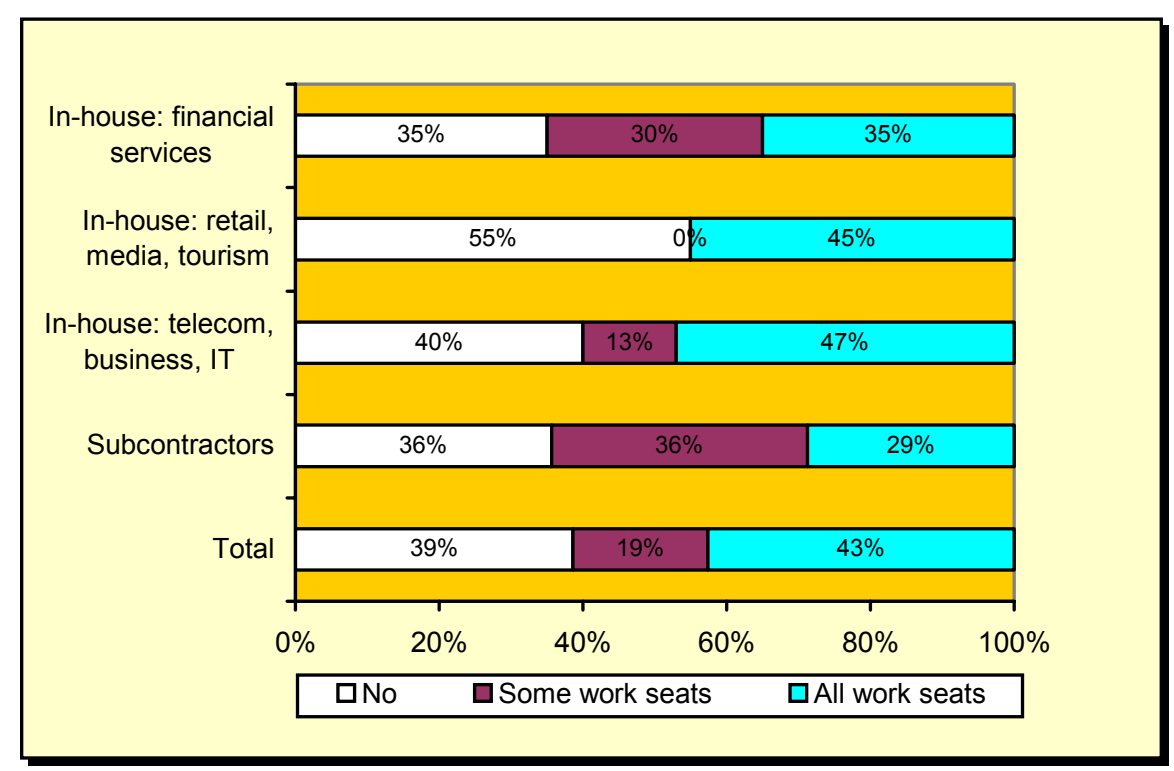


From our interviews, we learned that most call center managers are reluctant to introduce teleworking (i.e. the use of remote agents). Although call center work is very suitable to perform at home (all one needs is a phone and internet connection), managers see problems with coaching their agents. In interviews, managers explained that agents do not want to work at home because of the lack of social interaction with colleagues. For this reason, a large call center in retail offers special social programs to agents working at home in order to cultivate company morale.

Figure 4.6 shows that overall, almost half of the Dutch call centers that participated in this study (43 percent) have flat screens present at all work seats, whereas another 19 percent has flat screens at some seats. Flat screens, however, are less common in in-house call centers in retail, media, and tourism (45 percent). In general, the flat screens used are 17 inches in size.

In sum, working conditions appear to be better in call centers with high involvement HR systems. Agents working in these call centers often have work seats that are adjustable in height, not separated by partitioning walls, air-conditioned, and equipped with flat screens. Moreover, call centers with high involvement systems are more likely to have formal regulations on working conditions (Arbobeleid).

\section{Figure 4.7}

Absenteeism Rates

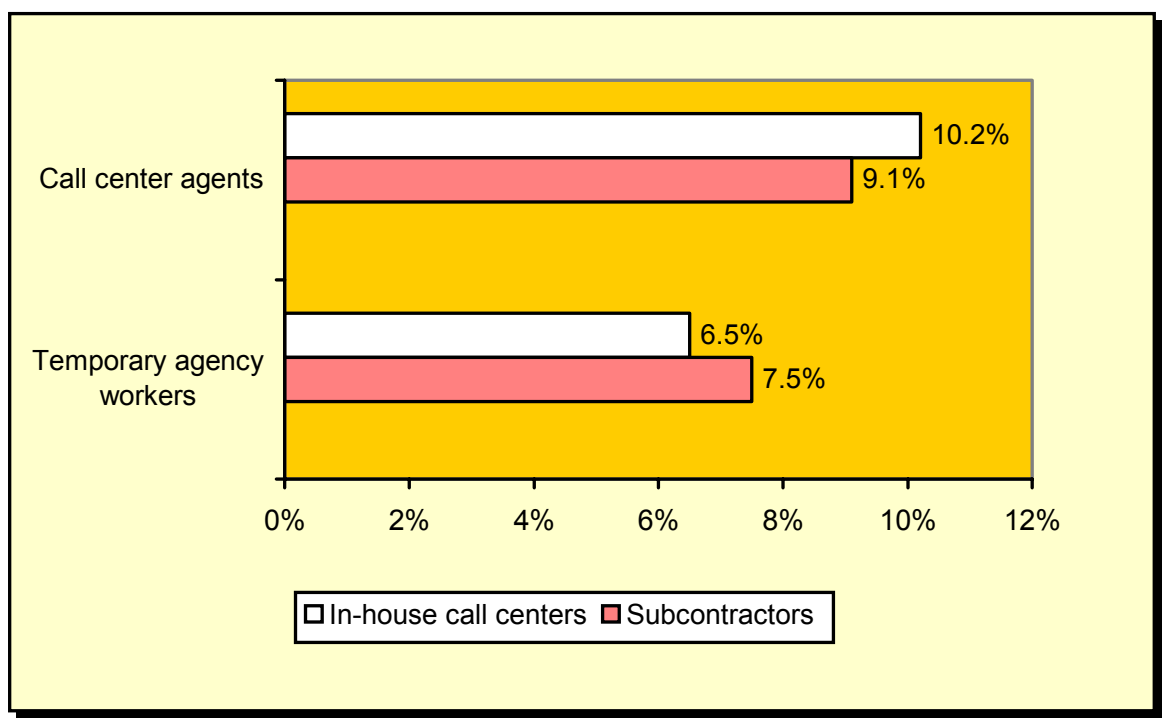

Finally, Figure 4.7 shows the absenteeism rates for Dutch call centers (maternity leave is excluded). Compared to other sectors of industry, the annual absenteeism rates for call centers are quite high, roughly 10 percent. ${ }^{19}$ The absenteeism rates for

19. The average Dutch absenteeism rate in 2003 was 4.7 percent (Source: Statistics Netherlands at www.statline.nl) 
temporary agency workers, however, are much lower: about 7 percent. Differences between in-house and subcontracting call centers are statistically not significant.

\subsection{Personnel Turnover}

Unlike the situation in cal centers in other countries, personnel turnover is not a major problem for Dutch call center managers. Particularly the past few years, turnover is relatively low, although there are some regional differences. Managers report turnover to be somewhat higher in the Randstad (urban area around Amsterdam-the Hague-Rotterdam-Utrecht) than in other parts of the Netherlands in part because of the availability of other job opportunities. U.S. industry analysts often estimate that turnover averages between 30 and 50 percent per year in the typical call center, although it can be much higher. When workers become bored or dissatisfied with their jobs, they often choose to quit, particularly if prospects for better opportunities are unavailable in their current organizations. On the other hand, call center management can also decide to dismiss some of their agents, for example, for economic reasons or because agents' skills are no longer up-to-date due to changes in technology or services. For example, most call centers nowadays are including more sales operations in their services. The combination of sales and services puts other demands on their agents: they need to be more sales oriented, and have commercial insights. Therefore, managers in Dutch call centers view turnover as healthy, and sometimes even want to increase it.

Figure 4.8

Total Employee Quit Rates

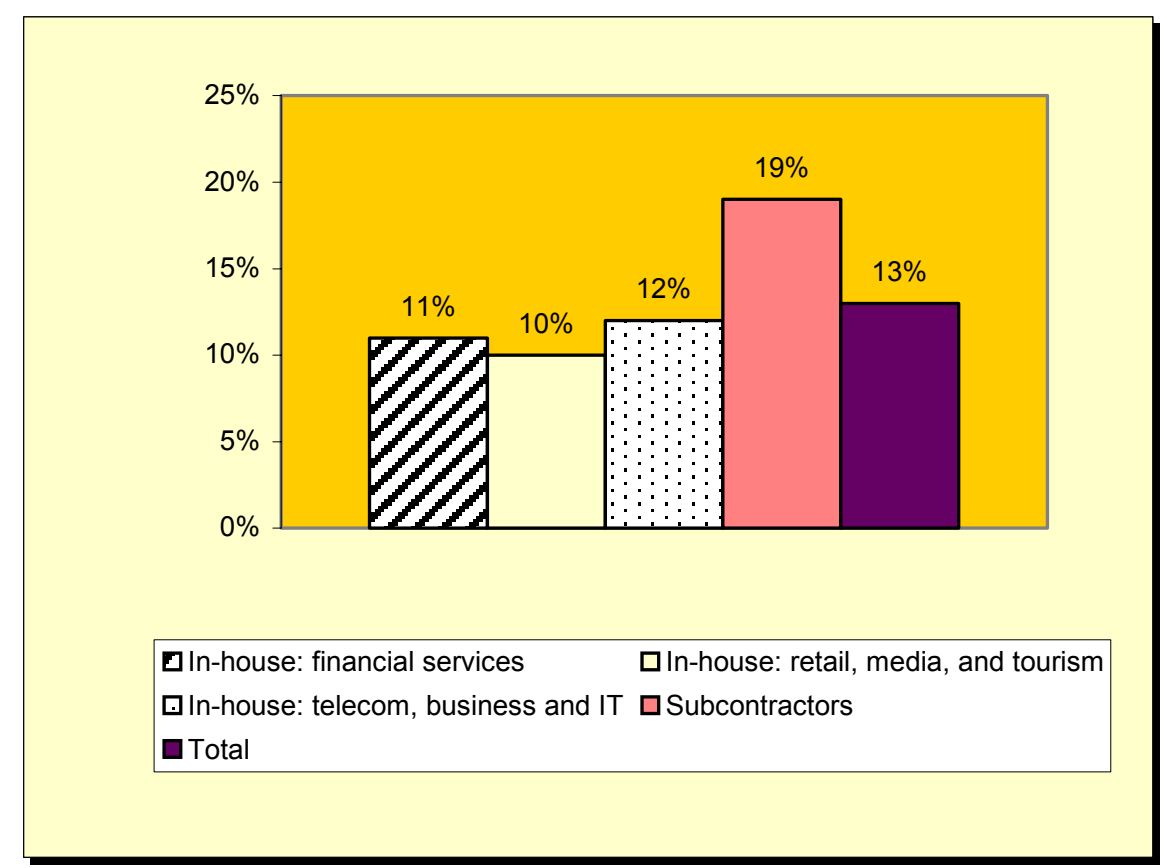


In the Netherlands, as Figure 4.8 illustrates, total employee quit rates are around 13 percent. Quit rates are highest for agents working in subcontracting call centers (19 percent) and lowest for agents working in in-house call centers in the retail, media, and tourism industry. Lower quit rates are found in call centers with high involvement (HR) systems (12 percent) compared to call centers with low-quality systems (16 percent). Again, call centers with intermediate HR systems are somewhere in between.

Subcontractors also have the highest voluntary quit rates, as Figure 4.9 illustrates. Annually, 8 percent of agents working in outsourced centers leave the organization, whereas for in-house call centers, this translates into 4 percent. In the interviews, call center managers mentioned many different reasons why agents left their organization. Some agents wanted a change in their work life, others moved to another part of the country. Students who do call center work often quit because they finished their education. 15 percent of call centers had agents leaving because they retired. All in all, less than 1 percent of call center agents retired in 2003.

Figure 4.9

Voluntary Employee Quit Rates

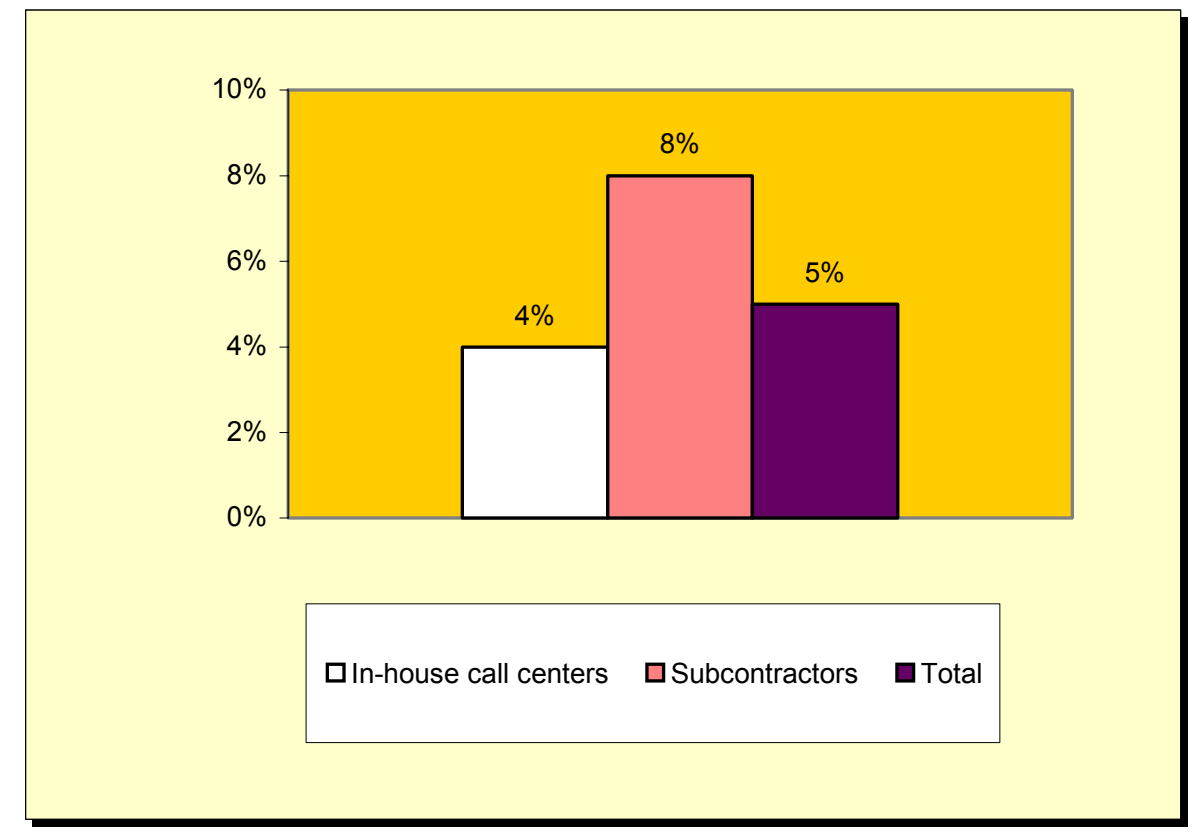

Although quit rates are relatively low in the Netherlands, a majority of call center managers find it important to reduce their turnover rates. After all, a higher level of turnover increases recruitment and screening costs for call centers and managers become locked in a perpetual search for additional workers. In this study, managers estimated that the costs to recruit, screen, and train each new agent averaged over $€$ 4,700.-- (see Figure 4.9). For in-house call centers the costs are much higher (nearly 
$€ 5,800$.--) than for subcontracting call centers (almost $€ 1,800 .--)$. These costs exclude the lost productivity of new employees.

Figure 4.10

Average Costs (in Euros) to Make a New Agent Operational (Inbound Agents Only)

\section{Euros}

8,000

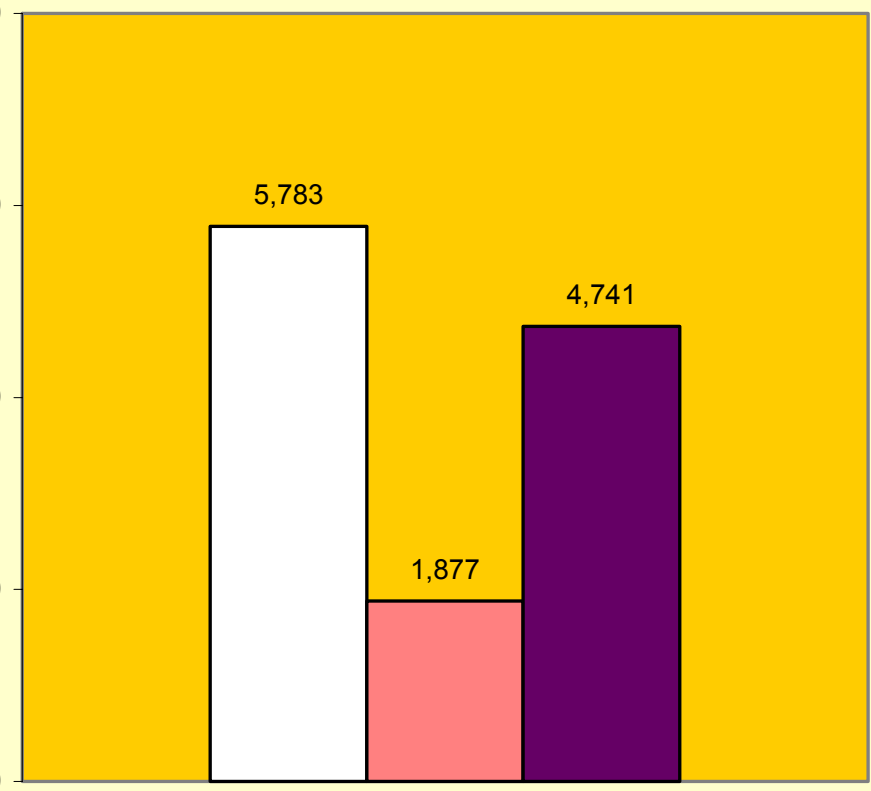

0,000

口In-house call centers

$\square$ Subcontractors

Total

On the other hand, about 15 percent of the call center managers participating in the survey think that it is not important to decrease employee quit rates. On the contrary, some managers even want to increase agent turnover. A manager of a telecommunications call center reported that they sometimes used scheduling as a lever to encourage people to leave. For example, agents who want to change their slot are not allowed to, and have to work at unpopular times like weekends and holidays. 


\section{Training and Career Opportunities}

\subsection{Training}

As indicated above, the majority of call center workers in this study have at least some college education. However, beyond a general education, call center workers need to develop specific knowledge of the firm's products, customers, and work processes - what is often referred to as 'firm-specific human capital.' Firm-specific human capital is important because call center employees manage the boundary between the firm and the customer, and they shape the customer's buying behavior. In order to persuade customers to buy a firm's products and services, employees need a clear understanding of specific product features, service agreements, pricing, packaging, promotions for particular customer segments, and legal regulations. They need customer-specific knowledge regarding the demand characteristics of particular individuals or segments and how to use that knowledge to negotiate customized offerings. Employees also require specific knowledge of the structure and content of the firm's information systems, the work flow from point of sales to delivery, and how the company's processing capabilities affect each customer and product offering.

Several models for training have emerged. Some call centers prefer to keep the training function in-house, while other call centers outsource it. In addition, the temporary employment agencies frequently provide basic training to newly hired agents, while the call center's training department focuses on improving agents' performance in the "last meter to the customer".

We asked managers to report the number of days of initial training the typical new hire receives. Figure 5.1 shows that agents dealing with inbound calls on average receive more training than agents dealing with outbound calls: 72 versus 46 hours. Particularly the inbound agents in the financial services receive much initial training: 105 hours. It is obvious that call centers operating in this sector need highly competent agents. This is probably related to the "from services to sales" business concept applied in many call centers in this sector, which transforms the call center from a 'cost center' into a 'profit center'. To be successful, these call centers therefore need agents who can both correctly deal with the complaints and questions of customers, and are able to sell financial services that match the customers' demands. However, the duration of initial training is related to the complexity of the job and the market segment the agents serve as well. For example, in a large Dutch bank, we found that agents who serve consumers receive initial training for 5 weeks, including two weeks of on-the-job training, whereas agents who serve business clients are trained for 6 weeks, including only one week of on-the-job training. Moreover, agents who deal with stocks or mortgages have to pass national exams for which they have to participate in additional training courses of substantial duration. 
Figure 5.1 also shows that, in general, agents employed by in-house call centers receive more training than agents who work in a subcontracting call center regardless of whether the agents are inbound and outbound. In contrast, outbound agents in the subcontracting firms hardly receive any initial training.

Figure 5.1

Hours of Initial Training for Inbound and Outbound Agents

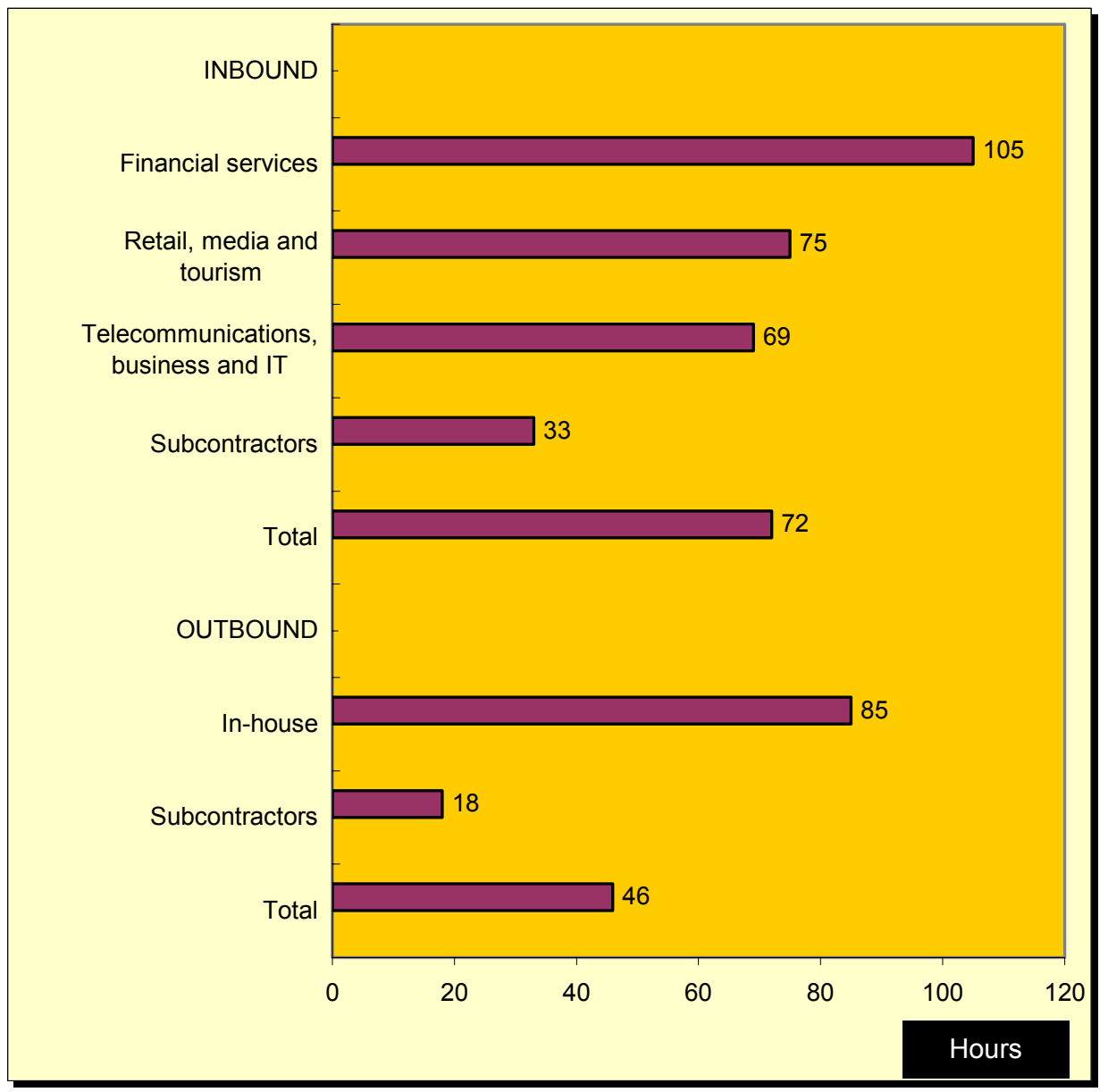

What kind of training do call center agents receive at the start of their job? Table 5.1 shows that for all agents knowledge of the products they have to deal with is the most important kind of training. Training in knowledge of products takes 22 percent (in telecommunications, business services, and IT) to 39 percent (in financial services) of total initial training time. This shows that in financial services, where initial training time is relatively long, firms invest by far the most in the product knowledge of their call center agents. Second-most important is training in conversation skills. However, this does not hold for the telecommunications, business services, and IT sector. This sector spends relatively more training time on firm 
specific knowledge. In general, outbound agents on average receive more or less the same mixture of training as inbound agents, with two remarkable exceptions: outbound agents spend relatively more time in training for telephone sales' skills and bargaining skills.

We also analyzed the kinds of training call centers with a high involvement human resource system provide. We found that these callcenters in particular emphasize the training of agent product knowledge (40 percent versus 21 percent for firms with a low-quality HR system) and also focus more on computer skills. In contrast, call centers with a low-quality HR system place more importance on training with respect to firm introduction, conversation, skills, and dealing with aggression.

For agents, it is usually important to receive a certificate of the skills acquired in the training courses in which they participated, because a diploma strengthens their external position in the labor market. Certificates are often related to a formal exam at the end of the training. Moreover, an exam of course also tests whether agents have mastered the skills required for their job. Figure 5.2 shows that only 32 percent of the call centers test the skills acquired during initial training by means of a formal exam. In financial services, there are more frequent formal exams. In addition, in call centers that have a high involvement HR system, skills acquired in initial training are examined on a more frequent basis: 47 percent.

\section{Figure 5.2}

Formal Exam After Initial Training

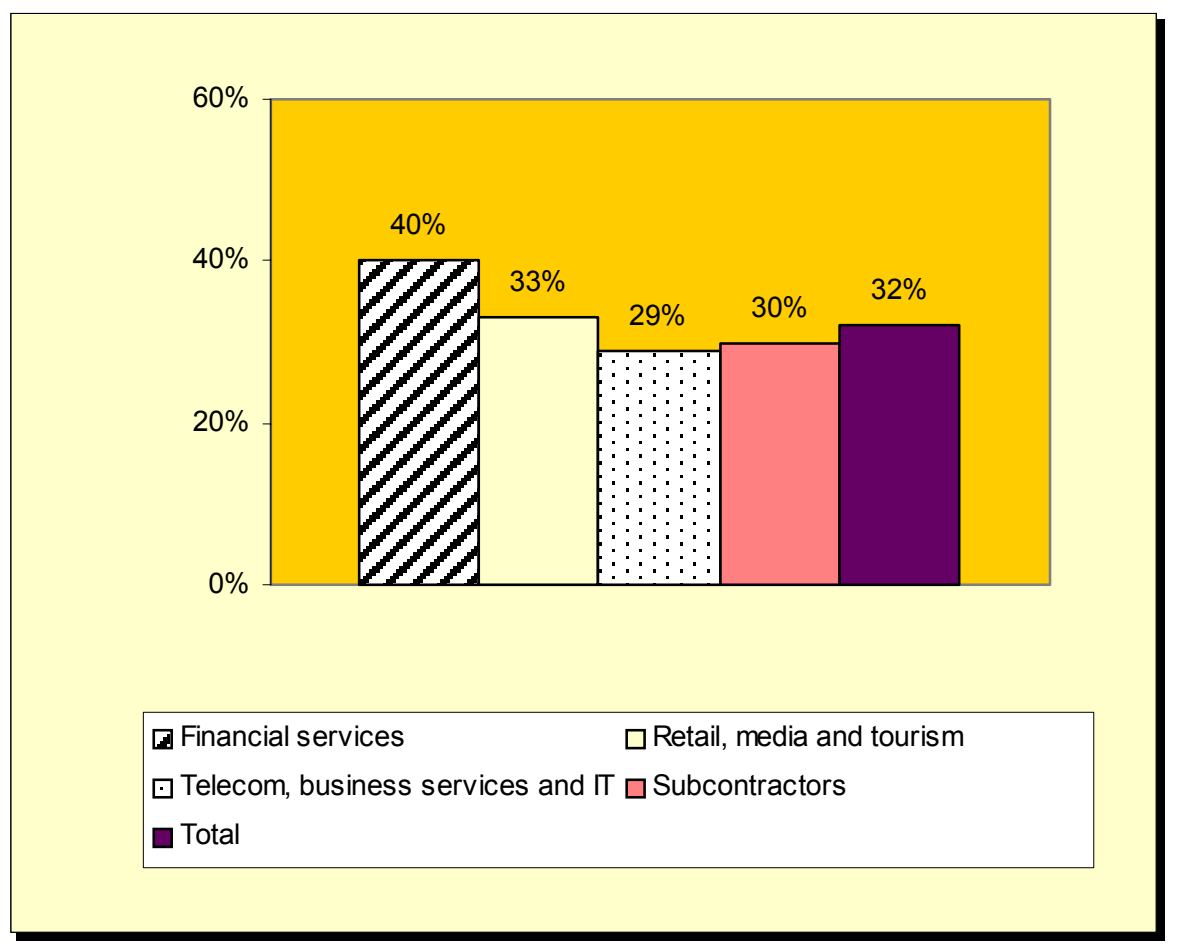


Table 5.1

Kind of Initial Training for Inbound and Outbound Agents

\begin{tabular}{|c|c|c|c|c|c|c|}
\hline & \multicolumn{5}{|c|}{ Inbound } & \multirow{2}{*}{$\begin{array}{c}\text { Outbound } \\
\text { Outbound agents }\end{array}$} \\
\hline & $\begin{array}{r}\text { Financial } \\
\text { services } \\
\%\end{array}$ & $\begin{array}{r}\text { Retail, media and } \\
\text { tourism } \\
\%\end{array}$ & $\begin{array}{r}\text { Telecommuni- } \\
\text { cations, business } \\
\text { services and IT } \\
\%\end{array}$ & Subcontractors & $\begin{array}{r}\text { Total } \\
\%\end{array}$ & \\
\hline Product knowledge & 39 & 24 & 22 & 25 & 27 & 23 \\
\hline Conversation skills & 14 & 15 & 9 & 19 & 16 & 16 \\
\hline Customer orientation & 8 & 10 & 12 & 7 & 9 & 7 \\
\hline Firm introduction & 4 & 6 & 11 & 5 & 7 & 5 \\
\hline Telephone sales & 5 & 6 & 4 & 8 & 5 & 16 \\
\hline Problem solving & 3 & 6 & 7 & 5 & 5 & 3 \\
\hline Motivation & 2 & 3 & 3 & 4 & 3 & 5 \\
\hline Dealing with aggression & 2 & 3 & 4 & 4 & 3 & 2 \\
\hline Stress control & 0 & 0 & 3 & 2 & 1 & 2 \\
\hline Bargaining & 1 & 1 & 1 & 2 & 1 & 6 \\
\hline
\end{tabular}


How long does it take a newly hired employee to become proficient on the job? The longer it takes for employees to become proficient, the greater the cost in lost productivity. On average, it takes 37 working days before inbound agents are proficient for their job (see Figure 5.3). However, in in-house call centers (e.g. 48 working days in telecommunications, business services, and IT) it takes much longer before a worker is adequately productive in the job than in subcontracting call centers (21 days).

For outbound agents, it takes much less time to become adequately productive on the job: 19 days. For those employed in a subcontracting call center, it takes on average only 13 days. This again illustrates the lower skill needs in jobs for outbound agents whose phone conversations are much more routine than the conversations of inbound agents that are more difficult to predict.

Figure 5.3

Days to Become Proficient on the Job for Inbound and Outbound Agents

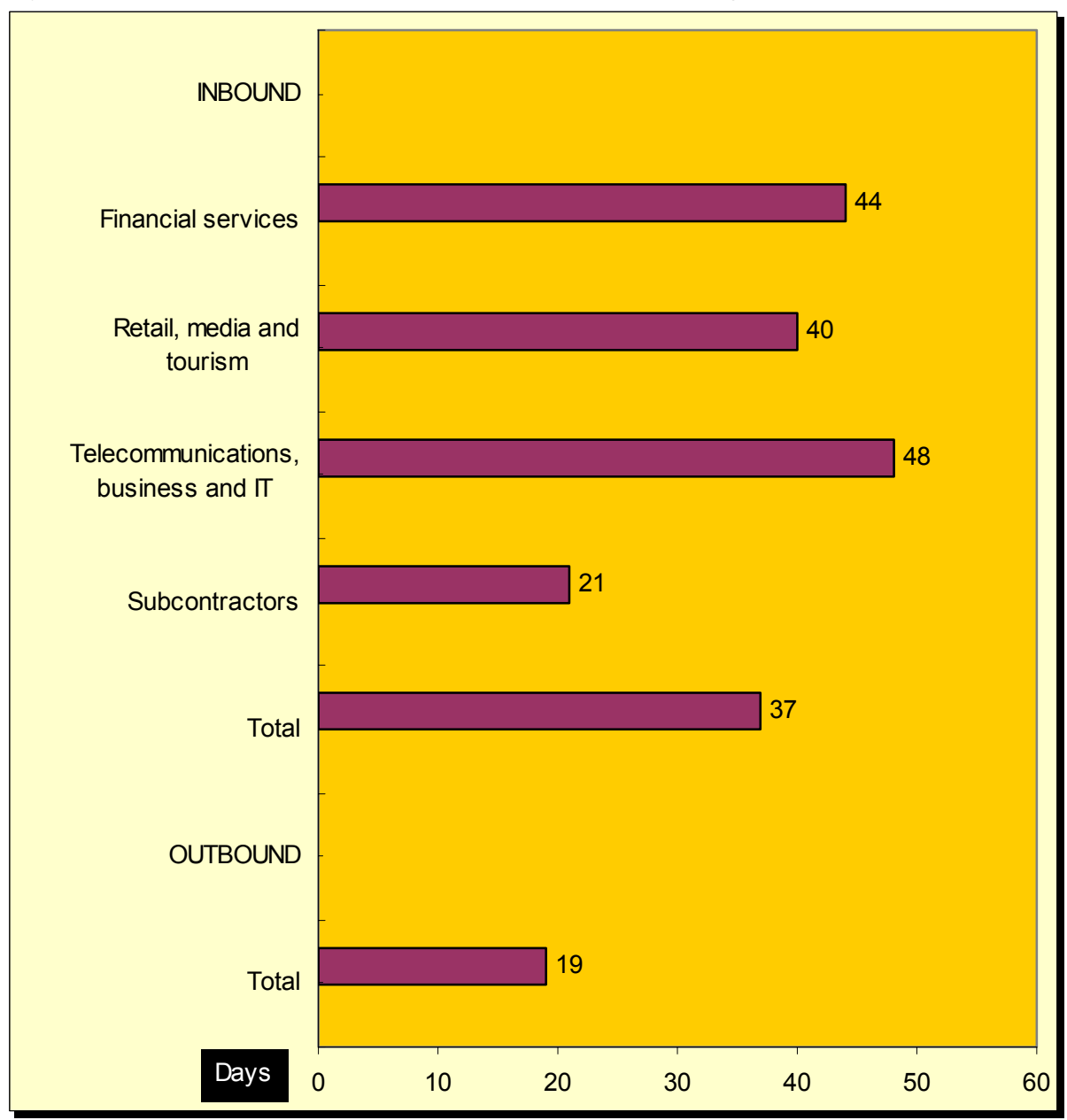


Among call center employers, much concern exists about the need to improve the image of call center work by professionalizing it. However, at the same time, employers are concerned about training costs such as technological advances within call centers increase the complexity of the work, whereas there are severe risks of poaching, as often firms may attempt to recruit agents who are trained in another call center. One avenue for dealing with this is to introduce call center training into the Dutch educational curriculum. The Education and Development fund ("O \& O Fund") of the call center sector, which is subsidized by the employers organizations, developed a profile for a call center employee education with the intent to integrate it into the Dutch system of initial vocational education in 2005. However, one might wonder whether such a specialized vocational study is interesting from a student's perspective, as for many students it will be more interesting to receive broader commercial vocational training in initial education.

\section{On-going Training}

Figure 5.4

Hours of On-Going Training of Inbound and Outbound Agents

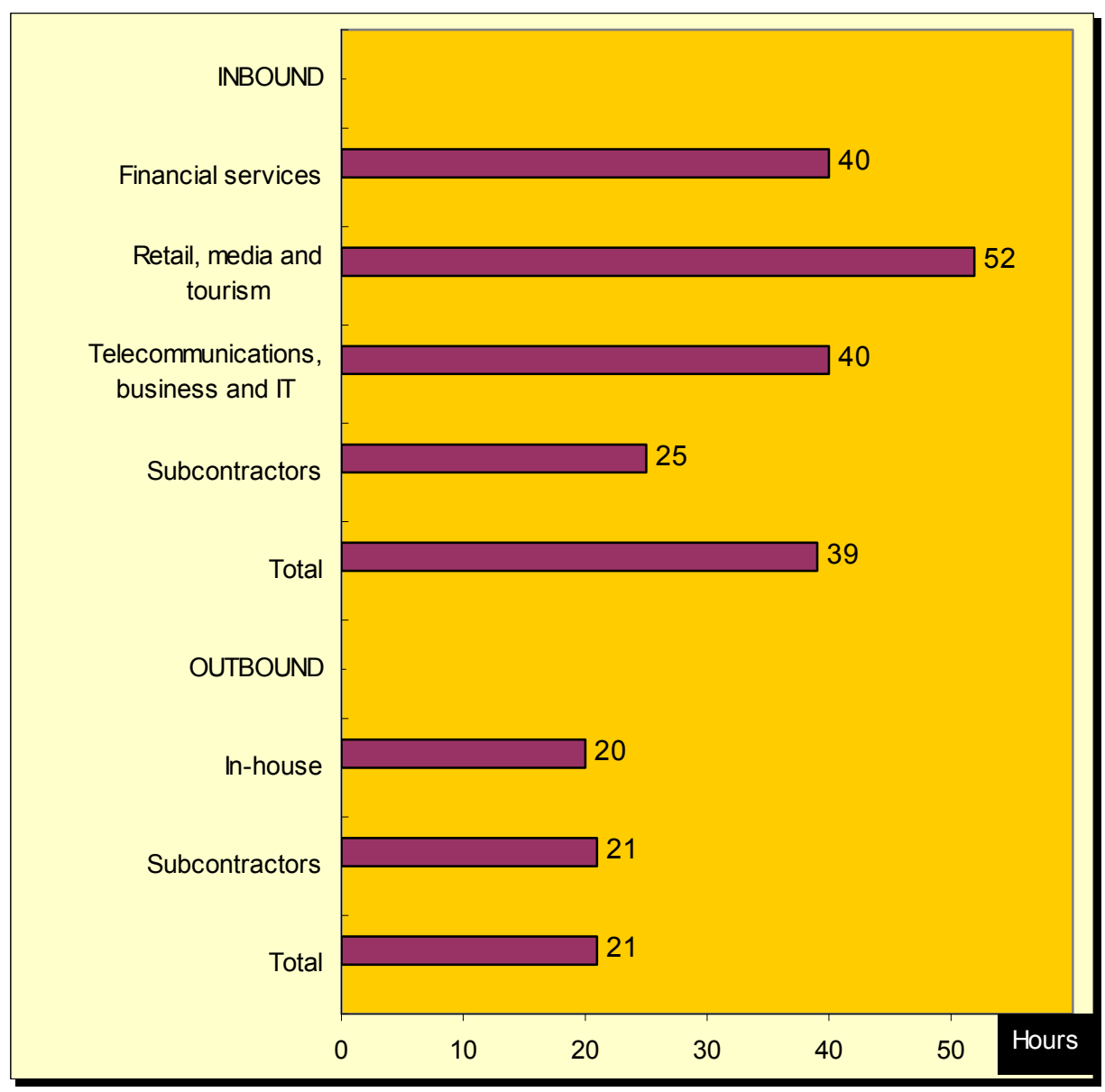


It is obvious that call center agents also need on-going training because the products, technologies, and services that employees handle are often changing at a rapid pace. Advances in information systems require employees to continually learn new software programs and databases. New technologies have also reduced product life cycles so that the features, packaging, and marketing of products and services are constantly changing. Thus, employees who provide service and sell products should need continuous learning and upgrading of their knowledge and skills.

Figure 5.4 shows that on average inbound agents receive 40 hours of on-going training in 2003. In comparison inbound agents, outbound agents receive much less training. Whereas the number of initial training hours is the highest in call centers in the financial services sector, the number of on-going training hours is the highest for call center agents in the retail, media and tourism sector. However, this provision of on-going training does not vary dramatically across the industries and sectors in the study. In contrast to the range of variation in education levels across sectors, we did not find higher rates of initial, or on-going training in centers serving businesses or providing IT services.

It is unclear whether the level of investment in on-going training of call center agents is sufficient, given the high demand for new skills and information-processing characteristic of these knowledge-intensive jobs. It should be noted that in the U.S., call centers provide twice as much (i.e. about two weeks of) on-going training each year to their agents.

Table 5.2 shows the types of areas inbound call center agents receive on-going training in. Again, most training focuses on product knowledge, followed by conversation skills and work procedures. Probably these are the key skills of call center agents that need to be regularly updated. There are actually only a few fields which more experienced agents receive relatively more training than new hires in: motivation, dealing with aggression, and stress control. In contrast, they receive much less training in the fields of computer skills and firm introduction.

Table 5.2

Kind of On-Going Training for Inbound Agents

Work procedures

Computer skills

Customer orientation

Firm introduction

Telephone sales

Problem solving

Motivation

Dealing with aggression

Stress control

Bargaining 
Altogether, call centers annually spend on average $€ 35,700$.-- as direct costs for the training of their agents, i.e. $€ 680$.-- per agent. Similar to the practice in almost all other sectors, firms pay the greater part of the training costs (97 percent); a small portion is paid by subsidizers ( 2 percent), and agents are responsible for only the remaining 1 percent. Altogether, 6 percent of call centers have agents who participate in a training program subsidized by the government.

Call centers are quite aware of the importance of increasing investment in the ongoing training of agents: 71 percent of call center managers state that it is important to pay more attention to on-going training, whereas only 2 percent report that this is unimportant.

Only a small number of call centers use e-learning software for the purpose of agent training: 11 percent of the in-house call centers compared with 15 percent of subcontractors. However, in the financial sector, 18 percent of the call centers use elearning software. In 2002, the WGCC, the Dutch employer organization for subcontractors, started an e-learning program with a large subsidy from the Dutch ministry of Economic Affairs. WGCC built a portal that agents can use to educate themselves using a computer (both at work during periods of low call volume, or at home). They also developed an e-learning exam which, after successful completion of the exam, agents can receive a certification.

\subsection{Career Opportunities}

Because call centers are flat organizations with few management levels, opportunities for better jobs are often limited. However, some call centers have found creative ways of retaining experienced employees, and using their skills more effectively. One approach is to have experienced agents handle more complex calls or complaints from irate customers. These call centers use skill-based routing systems to create tiers of jobs, with increasing levels of complexity. This is often connected with the various customer segments the call centers create to organize their services. Usually, higher level agent jobs entail dealing with the most important (i.e. higher value) clients. However, in a call center of a Dutch bank, the higher tier jobs are related to customers with the largest future growth potential. A second approach is to have experienced agents as coaches or on-the-job trainers, pairing them with new employees for training purposes. In addition, in-house call centers might offer their agents opportunities for promotions outside the call center, but within the larger organization - in exchange for serving a minimum period of time as a frontline customer service representative.

From our interviews with call center managers of a large Dutch financial institution, we learned that agents are first trained at "sales" level. Agents who do not reach this level are only allowed to work as "basic sales agents". For sales agents, there are ample career opportunities to be promoted from agent all the way up to unit manager. Like most other call centers we studied more in detail, this call center pursues the explicit policy of internally promoting agents to supervisory and managerial positions. Only when there is not enough supply, managing staff will be 
externally recruited. Internal bank careers also are possible, but the chances are fairly limited. Moreover, the back-office is not so much a career path because salaries for these jobs are generally lower than for call center jobs. This is because work in the back-office is simpler, and does not include customer contacts and therefore, it is not so much a high-risk profession.

Figure 5.5

Personal Development Plans (PDP) for Individual Agents

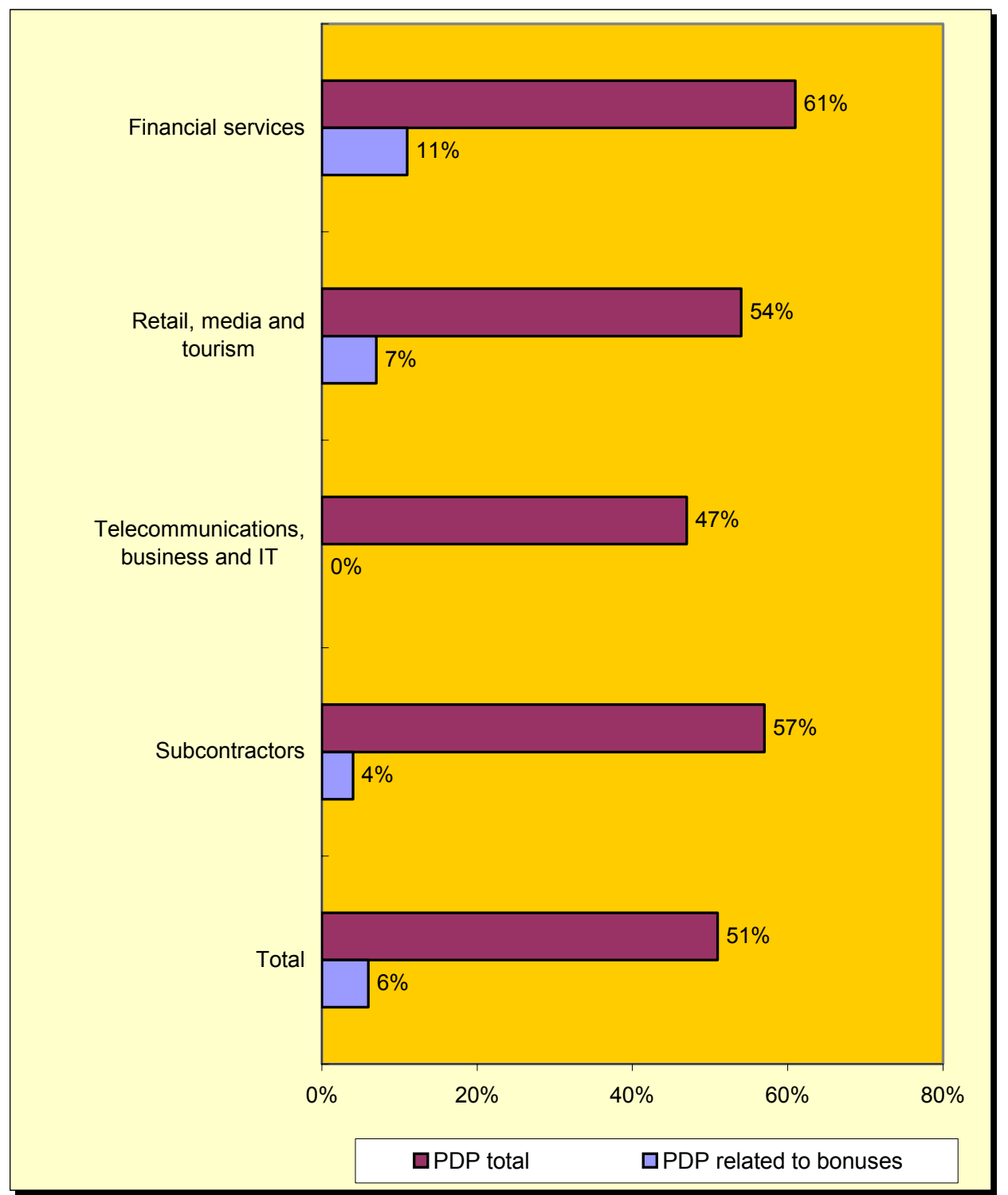

Like in many other sectors of the economy, it is becoming increasingly common for both in-house and outsourced call centers to introduce personal development plans for individual agents. Figure 5.5 shows that about half of all call centers have such 
personal development plans for their agents. Only 6 percent of call centers relate these personal development plans to the provision of bonuses. As mentioned in Section 2.1, we considered personal development plans as one of the possible features of call centers with a high involvement HR system.

About a quarter of all call centers (26 percent) apply some kind of job rotation for their agents, which may enable them to develop their skills more broadly. Although call center organizations are rather flat, 75 percent of call center managers report that their agents have opportunities for job mobility within the call center, whereas 61 percent reports that agents have opportunities for job mobility to other parts of the firm. 


\section{Industrial Relations and Collective Bargaining}

\subsection{Labor Relations}

In a relatively new sector of industry, labor relations generally are less developed than in sectors of industry that have long histories in this field. Of course, this is also true for the call center sector. Moreover, call centers often have ample opportunities to locate in regions where they experience less institutional pressures. Obviously, in English speaking countries, the opportunities for off-shoring call centers to low-wage countries are much larger than for call centers that serve the Dutch market. At the time of this study, only a few (in-house) call centers were off-shoring their calls to South Africa. However, in the Netherlands, several multi-lingual call centers exist that serve customers throughout Europe. Obviously, these call centers have large managerial discretion in the choice of their location. In this segment, the Netherlands is viewed as a competitor with Ireland.

A complicating factor for describing industrial relations in the call center sector is the duality between in-house and subcontracting call centers. In general, labor relations for in-house call centers are defined by the parent firm. From an industrial relations point of view, subcontractors are the real emerging new sector. Both types of call centers have separate employer organizations: the "Vereniging Contactcenters Nederland" (VCN) represents the interests of in-house call centers, while the "Werkgeversvereniging Callcenters" (WGCC) represents the interests of subcontracting call centers. Both organizations are quite nascent: WGCC was founded in 1998, whereas VCN started in 2003.

VCN attempts to convince firms that customer services provided by their in-house call center is crucial for their performance and that it is ineffective to merely focus on cutting the costs associated with maintaining relations with their current and potential customers. Moreover, VCN wants to improve the quality of Dutch call centers, for example by promoting certification of firms as well as their agents.

The WGCC, on the other hand, struggles with the fact that - opposite to the in-house call centers - subcontractors compete with one another for business. This is particularly salient for smaller call centers, because the largest Dutch call centers (SNT, BSC, and HCN) are prominent WGCC members. WGCC also wants to change the image of call centers by focusing on quality and professionalism. Among others, they are endeavoring to convince their membership that it is important to invest in agent training.

As Figure 6.1 shows, duality between in-house and subcontracting call centers is reflected in the extent to which call centers are members of an employer organization. Only 15 percent of in-house call centers participate in an employer organization for call centers. Almost all call centers in the financial services seem to completely focus their industrial relations in their own sector and not in the call center sector. 
In contrast, 48 percent of the subcontractors participate in a call center employer organization.

Figure 6.1

Membership of Call Center Employer Organizations

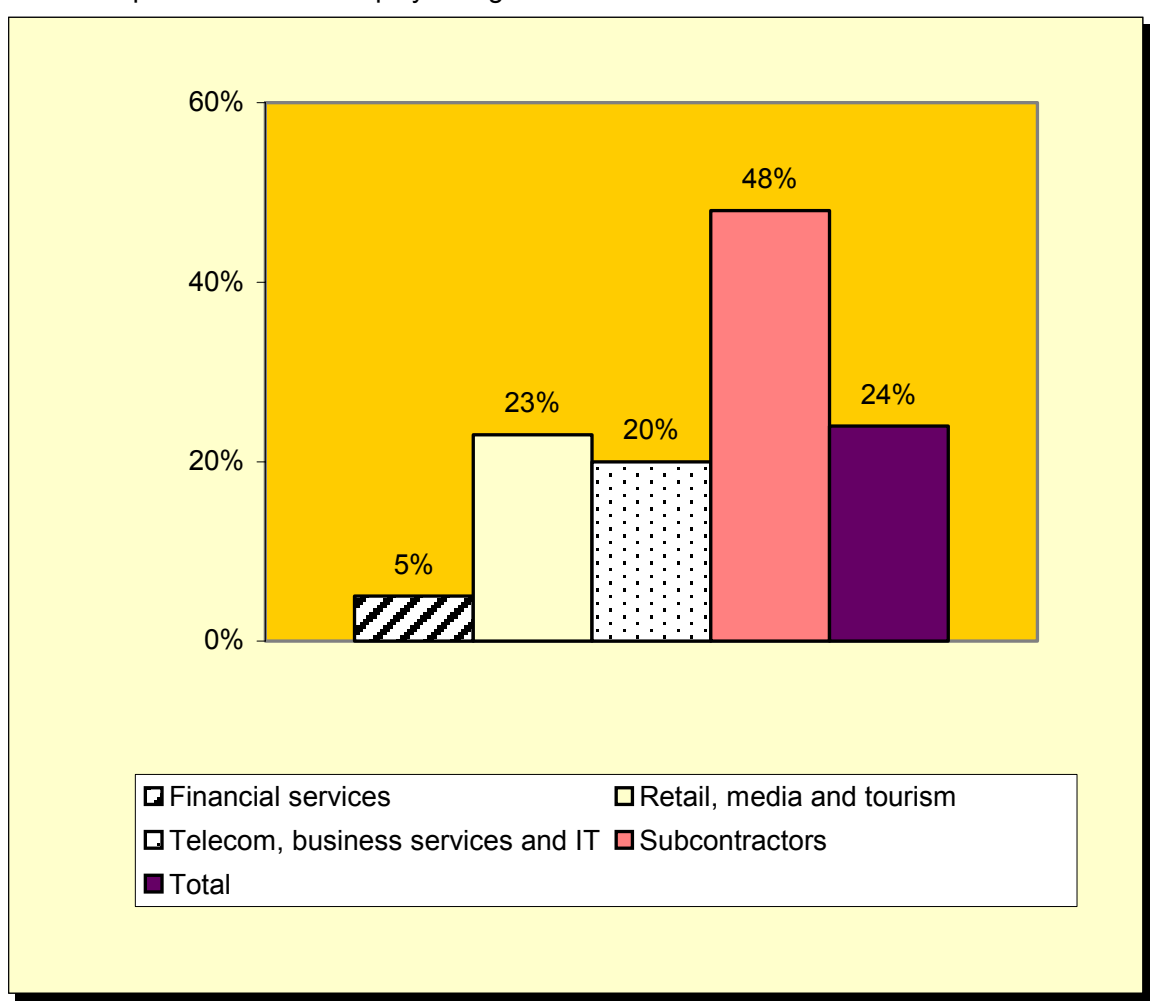

We also asked call center managers to indicate the percentage of union members amongst the agents in their firm. As could be expected, only a small number of call center managers (37) answered this question, because in the Netherlands, most firms do not know whether individual workers are union members or not. In the call centers that did know, on average 13 percent of agents is a union member, with a range from 0 percent to 75 percent. Data from FNV Bondgenoten, the largest Dutch trade union, however, show that union membership among call center agents is in reality much lower.

By law, any firm in the Netherlands with more than 50 employees is required to have a works council. As Figure 6.2 shows, almost all in-house call centers, and a majority of subcontractors have a works council. 
Figure 6.2

Works Council

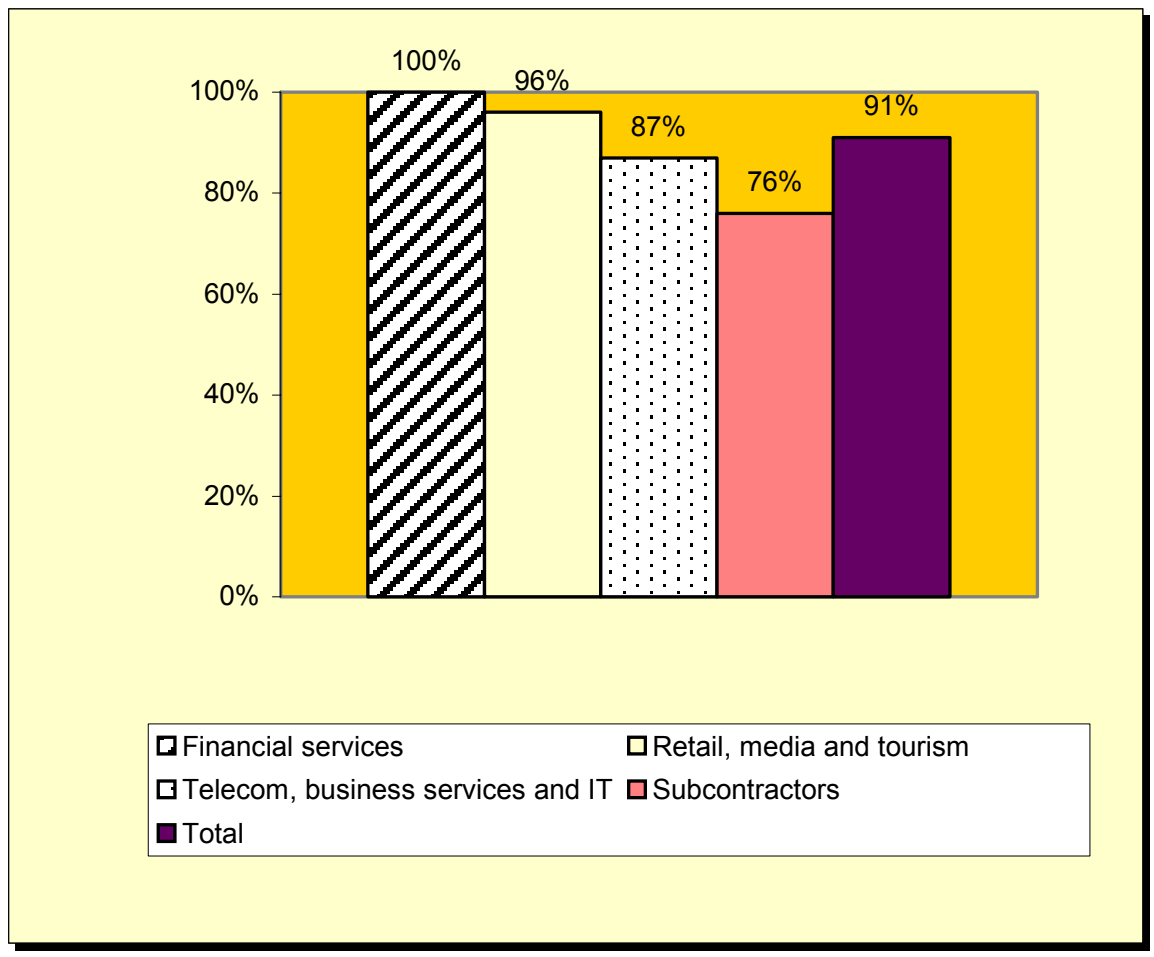

In the call center environment, the quality of representation by works councils, however, is low, because turnover is relatively high, and tenure is shorter compared with other industries. For this reason, we also asked call center managers whether some of their agents are members of the works council themselves. Figure 6.3 shows that in 54 percent of the call centers agents participated in the firm's works council. Call center agents more frequently are members of the works council in financial services and in the telecommunications, business services, and IT sector. It is remarkable that in only 29 percent of call centers with a high involvement HR system, agents are represented in the works council. This seems to suggest that a high involvement HR system in general could be a substitute for formal representation in the firm's works council. 
Figure 6.3

Call Center Agents Members of Works Council

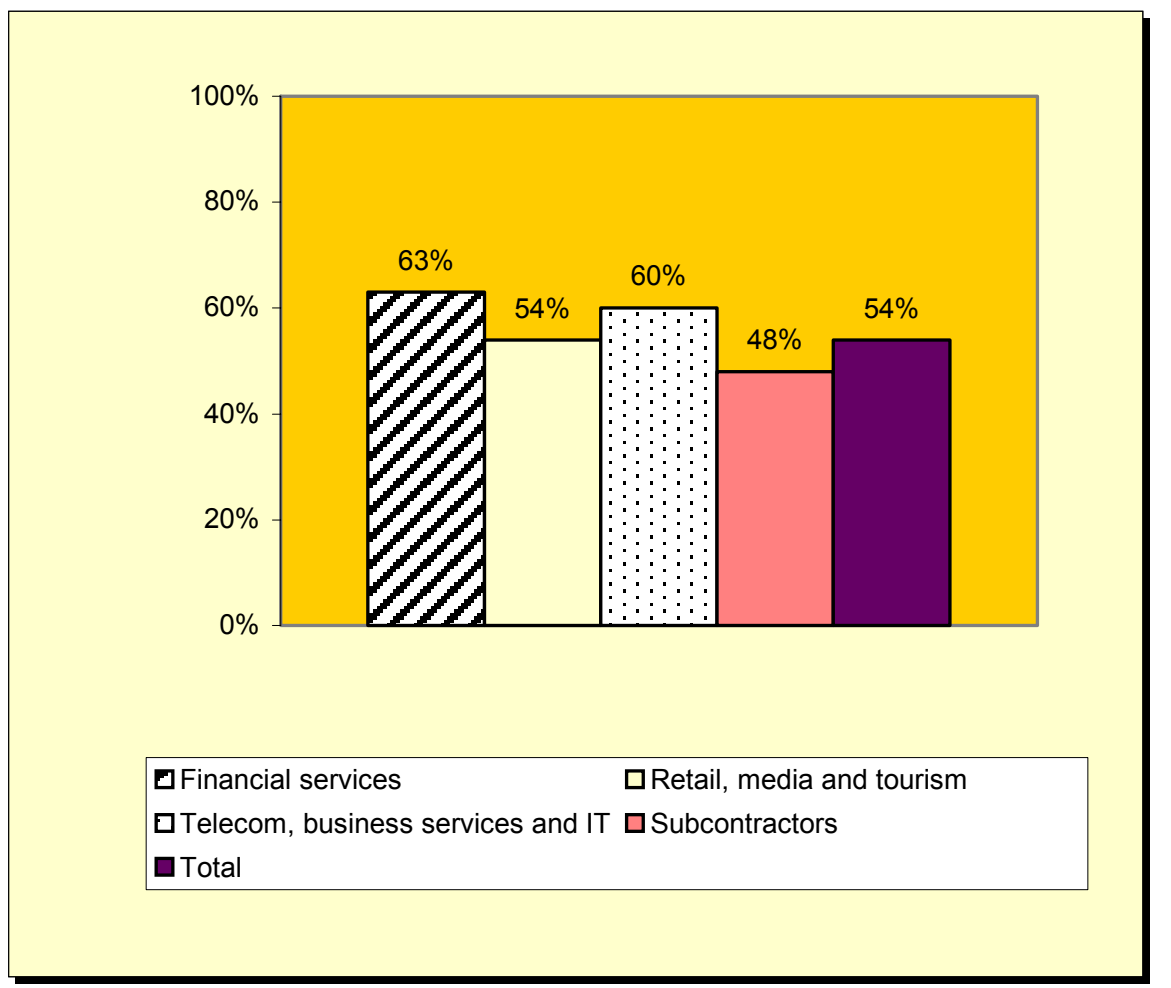

\subsection{Collective Bargaining}

Dutch unions have in general responded more quickly to the growth in nonstandard workforce than unions in most other countries. The temporary agency industry has a fifteen year old collective agreement, which is quite exceptional, compared to other countries. Dutch unions have been drawing on these experiences, and applying them to the call center setting. While the Dutch model has facilitated the proliferation of temporary jobs, it has also found ways to provide workers with protection from some of the downsides often associated with precarious employment relationships. Nevertheless, it still remains difficult to convince a worker in an insecure job to become a union member.

Industrial relations in Dutch call centers have several layers, and they shape the flexible employment strategies that employers can implement. First, company or sector level agreements define the working conditions for workers who are employed by an in-house call center. Second, workers on flexible contracts are usually employed at a temporary work agency. These workers are covered by the temporary agency sector agreement. Third, workers employed by a subcontracting call center are covered by the collective agreement for these call centers. 


\section{First CAO Subcontracting Call Centers}

In 2003, the employer organization for subcontractors WGCC and the Dutch union FNV Bondgenoten agreed upon a first collective bargaining agreement (CAO) designed for subcontracting call centers. ${ }^{20}$ It covers employment contracts (probation, termination), working hours, holidays, maternity and parental leave, salary, overtime pay, sick pay, and travel expenses. The main impetus behind the CAO was a desire to professionalize the business, and to improve the image of call center work to improve recruitment and retention. However, the subcontractors' sector CAO expired at the end of May, 2004, and at the time of this report, a new CAO has not been agreed to.

The first subcontracting CAO covered both full-time and part-time direct employees, but not the temporary workers who are covered by the CAO for the temporary agency industry. Actually, in subcontracting call centers, working conditions for temporary workers employed at a temporary agency may be more advantageous than working conditions for workers who are on permanent contracts, because the CAO for the temporary agency sector has been developed over the past fifteen years, whereas the subcontractors' sector CAO was first introduced in 2003. In contrast to the subcontractors' sector CAO, the CAO of the temporary work agencies' sector provides: (1) a pension fund, (2) a training interview at the end of 26 weeks of employment, (3) a percentage of salary costs committed to a training fund, and (4) permission to establish a works council within the temporary agency. The differences between the subcontractors' sector CAO and the temporary work agencies' sector CAO can create loopholes. For example, third party call centers can choose to have their temporary workers covered by the WGCC CAO as opposed to the temporary agency $\mathrm{CAO}$, enabling them to avoid paying workers additional money for working during the evening hours.

We asked call center managers whether working conditions in their call center were covered by a CAO. Figure 6.4 shows that the majority of call centers in our study (68 percent) were covered by a CAO. Particularly in telecommunications, business services, and IT, and among subcontractors, the percentage of call centers covered by a CAO is relatively low. However, some confusion for subcontractors may have arisen due to the CAO's expiration in the period, when the survey was administered. With respect to in-house call centers, call centers in the telecommunications, business services, and IT sector are generally not covered by a CAO, and mainly work with individual employment contracts.

20. Actually, this sector CAO was preceded by the company CAO of SNT, the largest subcontracting call center in the Netherlands. The SNT CAO still exists and is much more developed than the sector CAO. For example, it includes a pension scheme unlike the subcontractors' sector CAO. 
Figure 6.4

Collective Bargaining Coverage (CAO)

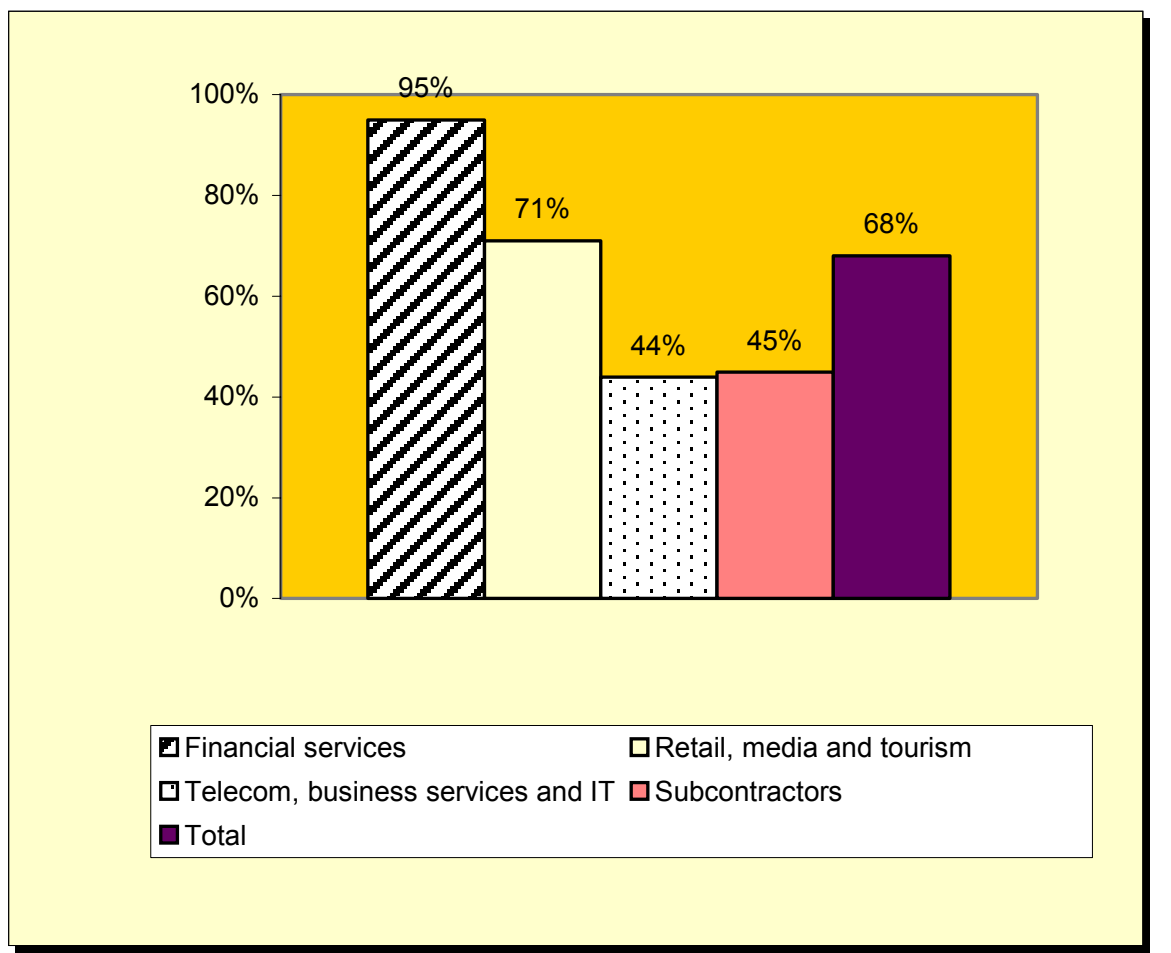

The first CAO for subcontracting call centers is quite remarkable when considered in an international context. In other countries, collective agreements on employment contracts in the call center sector are usually absent. Although it might lower management discretion with employee contracts, collective agreements obviously are a necessary tool for improving the image of call center work. This may have a positive effect on recruitment, and might reduce the high personnel turnover rates characteristic for call centers all over the world.

One might, however, wonder to what extent the first CAO increased labor costs for the subcontracting call centers. Table 6.1 shows that this has hardly been the case. Only a minority of subcontractors that participated in this study stated that the CAO affected individual employment contracts to some extent. From these results we may conclude that this CAO probably established a threshold for minimum renumeration, and holidays in call centers. It is apparent that this contributes to improving working conditions, and dramatically lower turnover rates compared with the U.S.. However, call center agents in subcontracting call centers in the Netherlands still have worse working conditions than those in in-house call centers, because in-house CAOs have been longer in place, and are, therefore, more extensive than the CAO for subcontracting call centers. 
Table 6.1

Effects of Subcontractors' CAO

As mentioned above, the CAO for subcontracting call centers expired in May 2004, and still has not yet been replaced. ${ }^{21}$ In the new CAO, FNV Bondgenoten wants to include a pension scheme and a job classification scheme, whereas WGCC is seeking more flexibility in the number of working hours per year. WGCC is very reluctant to include a pension scheme and a job classification in the new CAO. This may be due to the fact that WGCC represents a heterogeneous group of employers who are mutual competitors. Moreover, the first CAO established a minimum level of working conditions and there are several subcontractors that offer higher wages and fringe benefits beyond the CAO.

FNV Bondgenoten compares the CAO development in the call center industry to the $\mathrm{CAO}$ development in the temporary employment agencies sector. In the latter sector, it took fifteen years to develop a proper CAO. FNV Bondgenoten hopes that it will take less time than this in the call center industry given the lessons from the temporary employment agency sector. Characteristics of temporary staffing workforce and call center workforce are quite similar (short tenure, young mobile workforce), and, therefore, Dutch unions are somewhat hopeful that they will be successful in improving working conditions in third party call centers. According to an FNV spokesman, salaries for Dutch call center agents are "15 to 20 percent below the market". However, it is difficult to determine what exactly the market level is, since the various job levels of call center agents are not clearly defined.

We asked call center managers which issues they would like to include in collective bargaining in the future. The available data do not allow us to distinguish between subcontractors and in-house call centers. Table 6.1 shows that many call centers are willing to include more issues in a future CAO. Almost two-third of call centers is eager to include performance pay schemes. More than half of call centers support including agreements on job-specific training, whereas approximately 40 percent of call centers would like to include agreements on pensions, childcare facilities, and performance evaluation interviews in the future CAO. Most call centers oppose including regulations for saving training days.

21. It should be noted that several Dutch sectors of industry did not renew their CAO last year, mainly because of disagreement on changes in early pensioning schemes related to important changes in tax relief for early pensioning announced by the government. 


\begin{tabular}{lrr} 
& $\begin{array}{r}\text { Yes } \\
\%\end{array}$ & $\begin{array}{c}\text { No } \\
\%\end{array}$ \\
\hline Performance pay & 63 & 21 \\
Job-specific training & 53 & 23 \\
Pensions & 43 & 26 \\
Childcare facilities & 39 & 29 \\
Performance evaluation interviews & 39 & 34 \\
Saving training days & 2 & 51 \\
\hline
\end{tabular}

\subsection{Some Comparisons with Germany}

It should be noted that the Dutch CAO for subcontracting call centers is quite unique in the international context. In Germany, for instance, unions have been unsuccessful in setting up anything like this for the call center sector: there is just one major firmlevel collective agreement in a subcontracting call center. This agreement was negotiated in 2003. However, it is weak and does not cover pay.

In Germany, only a quarter of call centers is covered by collective bargaining. About half of these contracts are at the firm level. The coverage of collective bargaining is even much lower for subcontractors, with only 16 percent covered by a collective agreement, including three-quarters at the firm level.

Moreover, the rate of membership in employer organizations is much lower in Germany compared with Dutch call centers. 48 percent of subcontractors in the Netherlands is a member of an employer organization, whereas in Germany, only 10 percent is. In addition, although the percentage of call centers with works councils is close to 50 percent in both the Netherlands and Germany, a huge 'representation gap' exists between in-house call centers and subcontractors in Germany: While 70 percent of in-house call centers have works councils, only 23 percent of the independent subcontractors do. As shown in section 6.1, these numbers are much more even in the Netherlands: 57 percent versus 46 percent.

How do we explain this? First, Dutch unions have incorporated certain demands for flexibility in their agreements, based on their experiences in the temporary staffing industry that developed much earlier than in Germany. Although Dutch unions are weaker, they have worked closely with employers and the government to come up with innovative strategies that offer some protections to employees in non-standard employment relationships. German unions were slower to react - in part because of strong works councils - and they tended to focus on protecting their "core" workers. In many cases, works councils allowed employers to outsource work rather than accept conditions like "unsocial" working hours (weekends, holidays, and late nights) and more flexible shift planning. 
Second, employment contracts are also an important source of difference. In the Netherlands, employers must request permission from the labor office to terminate a contract. If permission is granted, the employer is not required to provide the employee with severance pay. Therefore, it is somewhat easier to lay off workers. In Germany, permanent employees have more rights, and protections against termination without cause. Both countries now have legislation that allows employers to hire employees on short-term contracts, which convert to "permanent" contracts after 3 years with one employer - but these are more recent in Germany, and employers have been slower to use them.

Differences in organization rate of the subcontractors' sector between Germany and the Netherlands are hardly reflected in the relative wages of agents employed in subcontracting call centers. Whereas German agents employed on a permanent contract in a subcontracting call center earn on average 21 percent less than those who are employed in in-house call centers, in the Netherlands, this difference is only slightly smaller: 18 percent. In both countries, wage differences for temporary workers are larger: 28 percent in Germany, compared to 25 percent in the Netherlands. However, the Dutch subcontractors' CAO does not appear to have diminished the competitive power of these call centers in the Netherlands. 